السرد النسائي في الرواية الليبية

$$
\text { دراسة في الأدب الليبي }
$$

\title{
إعـداد الطالبة
}

هناء علي علوان القتصل

طالبة دكتور اه قسم اللغة العربية بالكلية
معساونة
إثتــــر اف
د العيمة مر اد
أ.د/ يوسف حسن نوفل
مدرس الأدب الحديث
أستاذ الأدب والنقد العربي الحديث
كلية البنات - جامعة عين شمس

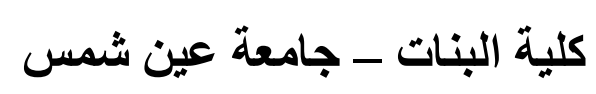


استطاعت الأديبة اللبيية فرض نفسها على الساحة الإبداعية منذ خمسينيات القرن العشرين

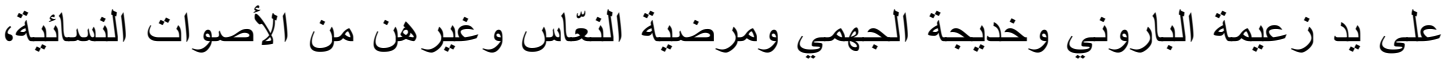

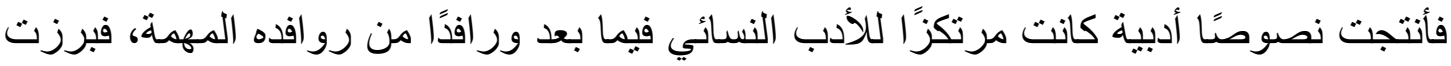

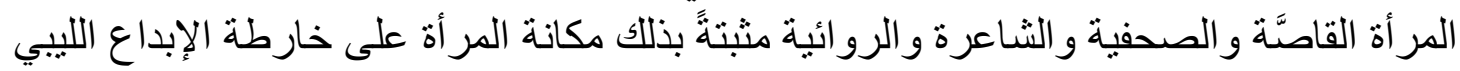
و العربي.

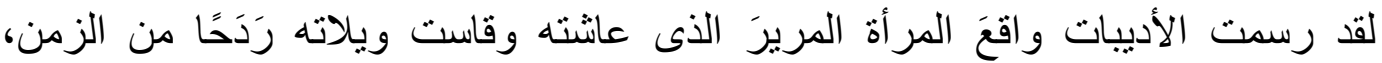

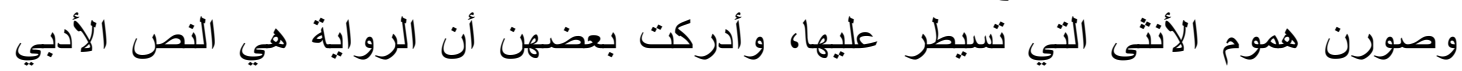

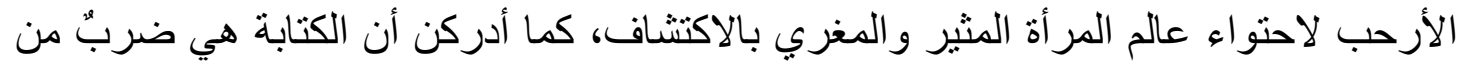

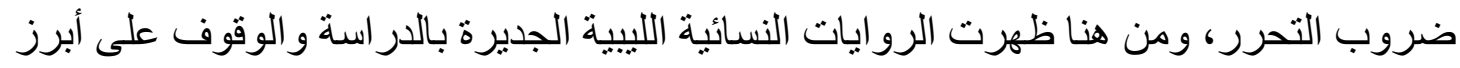
السمات التي تميز هذا النص الإبداعي.

و تكمن أهمية الفّن الروائي في نقله صورةً المجتمع بما يحويه من مشاكل و أزمات ومظاهر

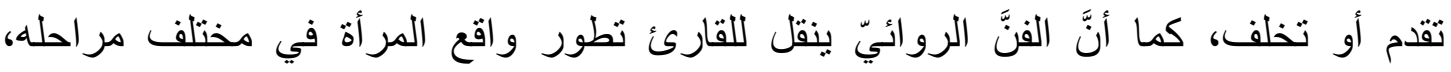

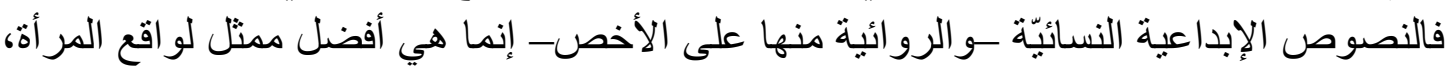

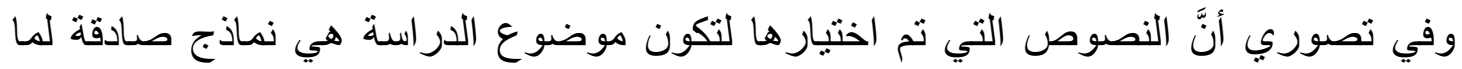
كانت تعانيه المر أة الليبية ـباعتبار ها أنتى- خلال الفترة الممتدة من السبعينيات حتى التسعينيات

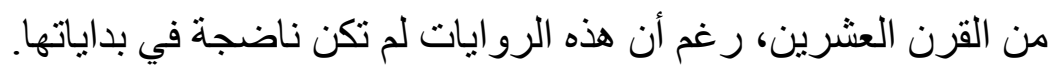

ستحاول الباحثة في هذه الرسالة رصد بعض الروايات الليبية وموضو عاتها ومدى تعبير ها

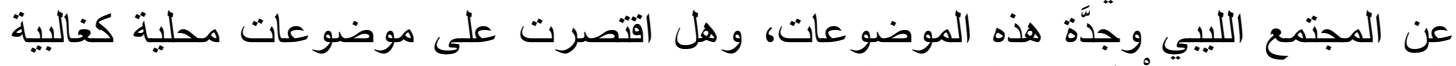

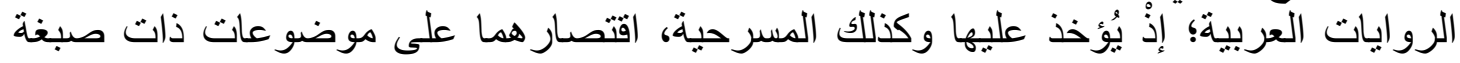

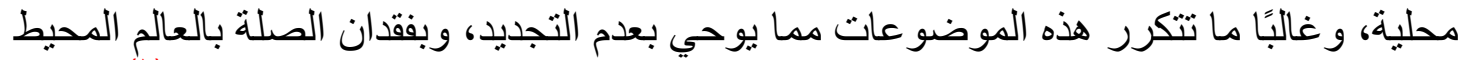

بنا... وليس لنا أن نغالي في الاتهام فنسم القصة العربية بوجةٍ عامِ بتقوقعها و انطو ائيتها. (') ومن هذا المنطلق كان اختياري لار اسة الأدب النسائي الليبي، وجعلتُ عنوان البحث: (السرد

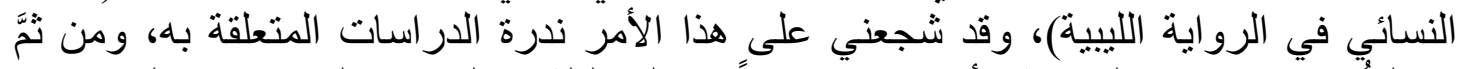

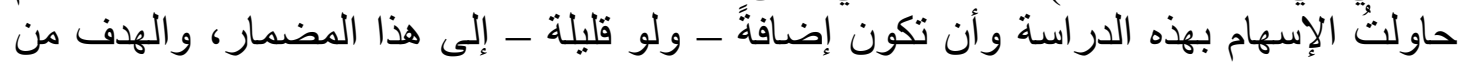
الدراسة هو الإعلاء من شأن النص النسائي، وإبراز الإنهان مشاركة المرأة الليبية في الحركة الأدبية بليبيا.

وستأتناول في هذا البحث التعريف بالروائيات صاحبات النصوص المستهدفة بالدراسة،

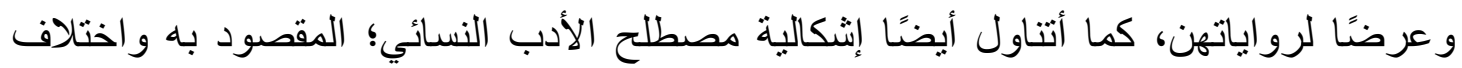

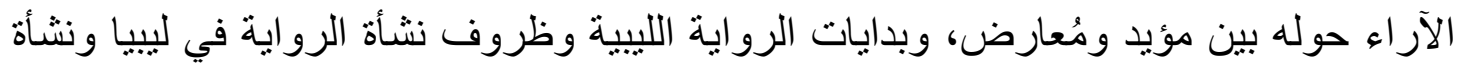

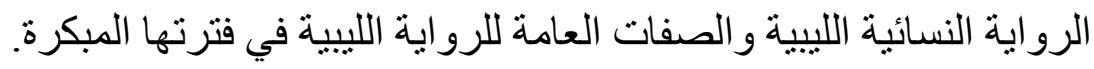

\section{والله ولي التوفيق}

(1) د يوسف نوفل، في القصة العربية، ص 1 و و، الهيئة العامة لقصور الثقافة ـ مصر، سلسلة كتابات نقدية 


\section{التعريف بالأديبات صاحبات النصوص موضوع الدر اسة}

يجدر بنا في البداية قبل الولوج إلى الحديث عن السرد النسوي في ليبيا أن نُعرِّف بأهم

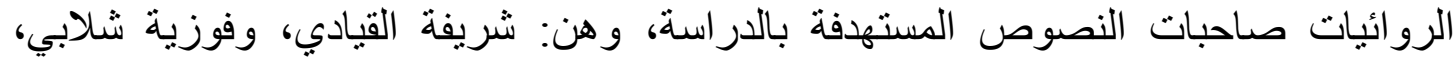

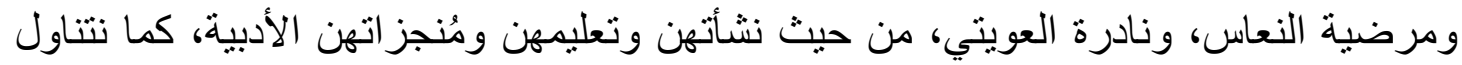

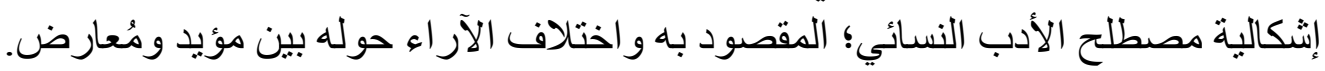

لكن ما أودُّ نسجيله هنا قبل الثروع في الحديث عن الروائيات الليبيات هو أنَّ من النقاد الكياد

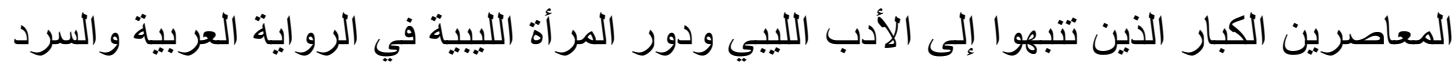

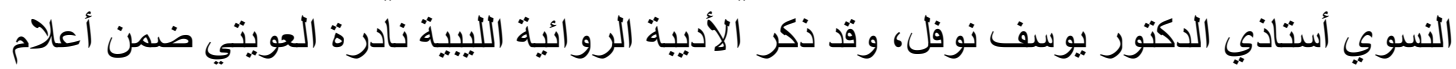

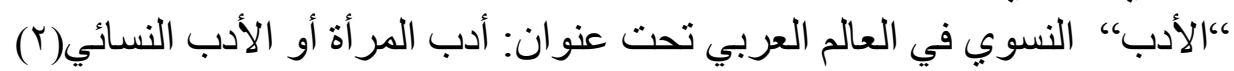

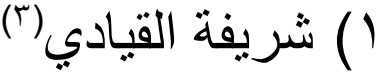

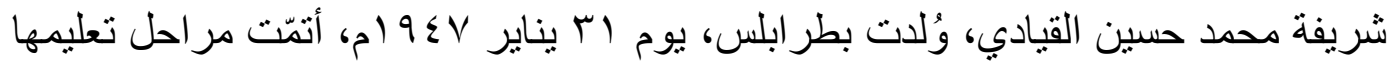

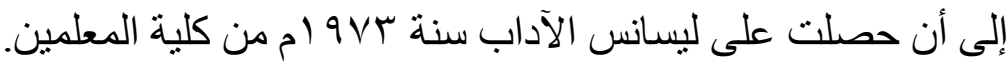

تزوجت قبل إنهاء دراستها الجامعية وسافرت مع زوجها إلى أمريكا، وهنالك التحقت بكلية

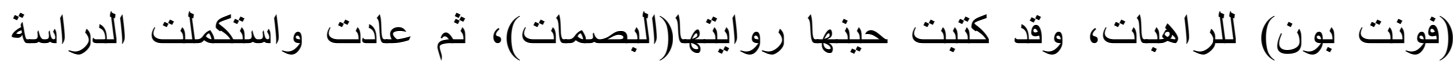

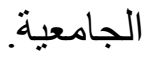

بعد ذلك سافرت في صحبة زوجها إلى بريطانيا، وهناك أنجزت جزءًا من رو ايتها: “،ذه أنْا، ،

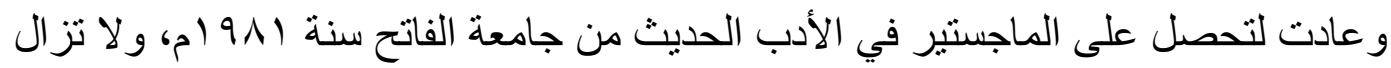
تز اول مهنة التدريس بنفس الجامعة في قسم اللغة العربية. نشرت في عدد من الصحف والمجلات من بينها: "الر ائْ، و "الفجر الجديد"، و "الأسبوع الثقافي"، و "مجلة الإذاعة الليبية"، و"البيت"،

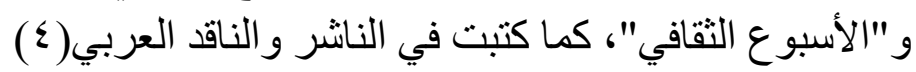

(r) انظر كتابه: الأدب الدديث في العالم العربي ومصادر دراسته، ص بآ ا، الثركة المصرية العالمية للنشر

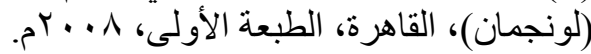

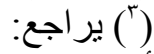

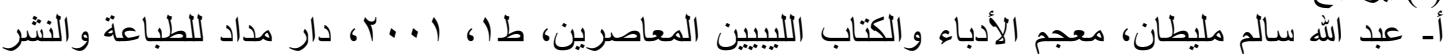

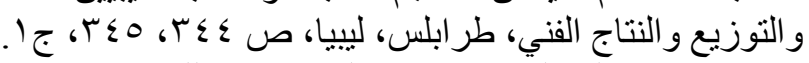

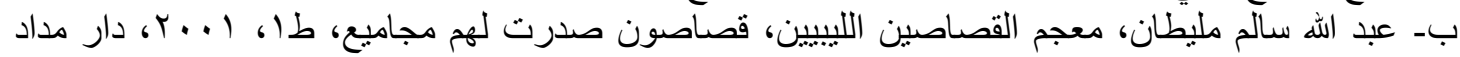

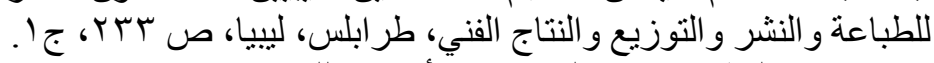

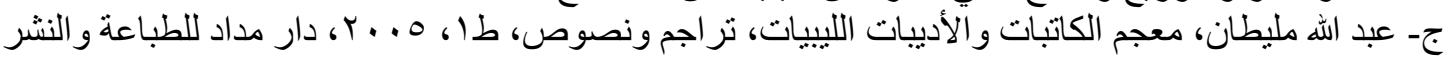

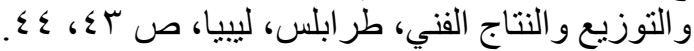

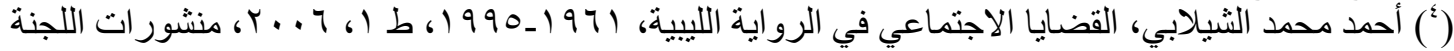

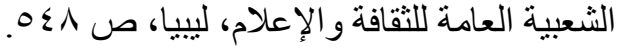


شاركت في عدة ندوات حول المرأة خلال فترة ترؤسها العديدَ من المؤتمرات الأدبية

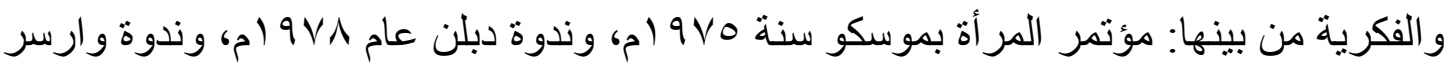

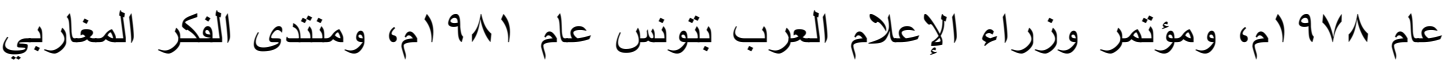

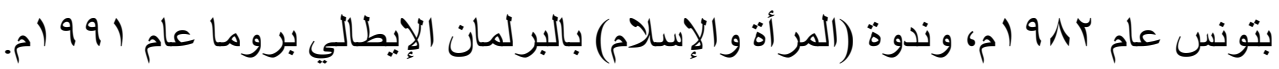

تولت عددًا من المهام الإعلامية والثقافية، من بينها: أمين لجنة تحرير صحيفة الأسبوع النقافي، وأمين لجنة تحرير صحيفة الأسبوع السياسي، و أمين لجنة تحرير صحيفة الجماهيرية، لإنة

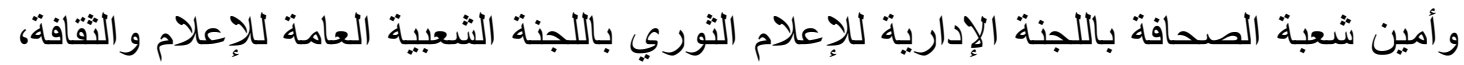
و أمين اللجنة التنفيذية لمشروع تنظيم وإدارة المدينة القديمة، والأمين المساعد للجنة الثعبية

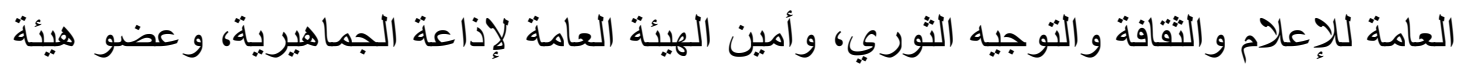

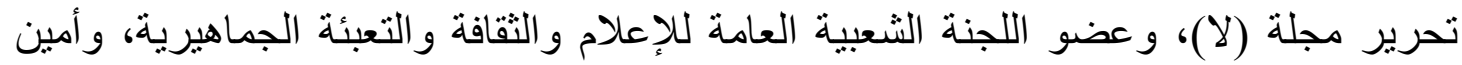

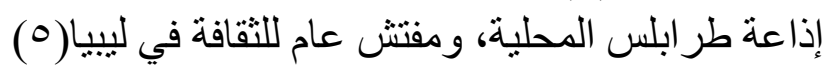

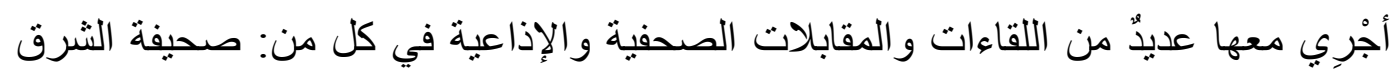

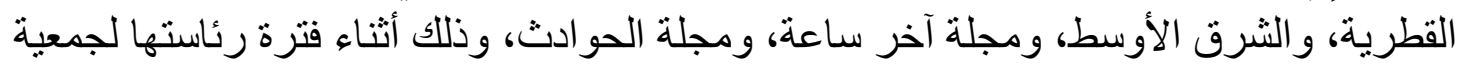

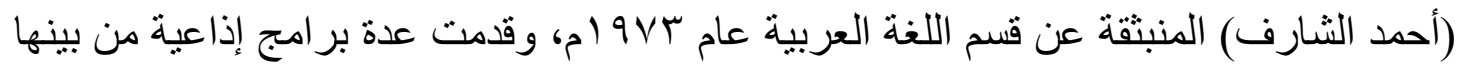

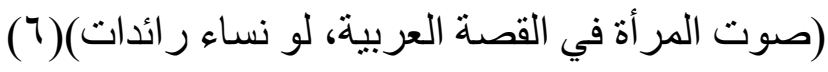
من مؤلفاتها ما بلي:

ا. هدير الثفاه الرقيقة (قصص قصيرة)، المنشأة العامة للنشر والتوزيع والإعلان، طر ابلس، م) ץ. تشع قصص قصبرة، بالاشتراك مع آخرين، المنشأة العامة للنشر والتوزيع والإعلان،

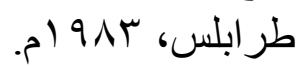
ץ. كأي امرأة أخرى(قصص قصيرة) المنشأة العامة للنشر والتوزيع والإعلان، طر ابلس، . $9 \wedge \varepsilon$

ع. من أور اقي الخاصة، خو اطر طر ابلس، المنشأة العامة للنشر و التوزيع والإعلان، عـ9 أم.

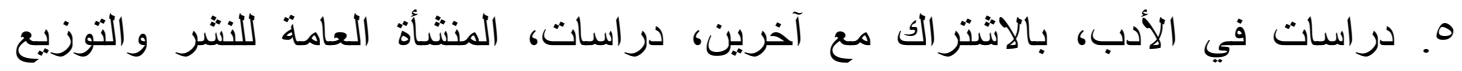

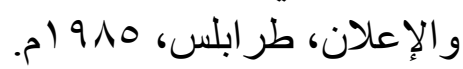

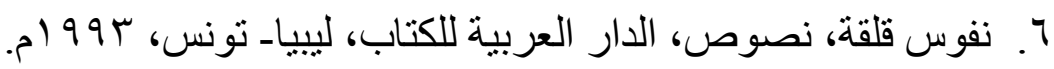

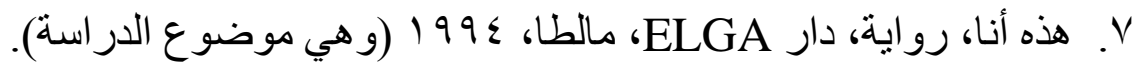

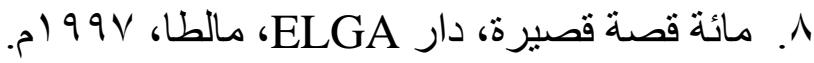

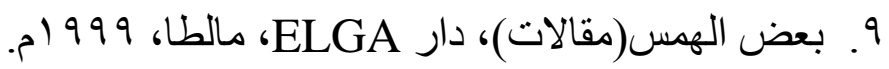

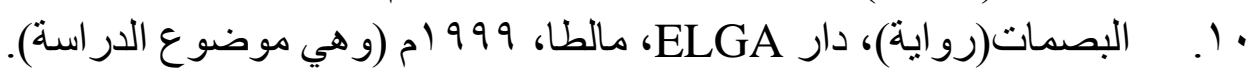

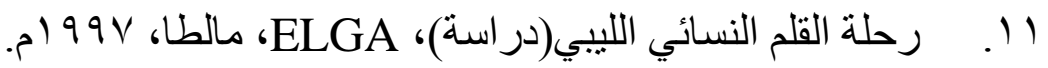

(") عبد الله مليطان، معجم الكاتبات والأديبات الليبيات، ومعجم القصاصين الليبيين، قصاصون صدرت لهم

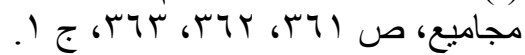

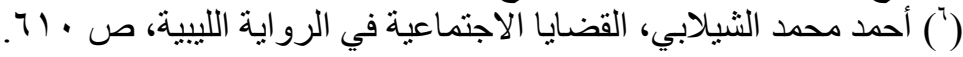


r 1. . إسهام الكاتبة العربية في عصر النهضة، در اسة، دار ELGA، مالطا، 999 (م. rا

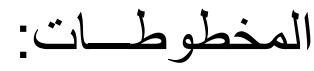

دعونـا نحب (قصص)، وقصص تدعو للتفكير(قصص)، وما خطنَّه الأنامل(مقالات)، و البوح

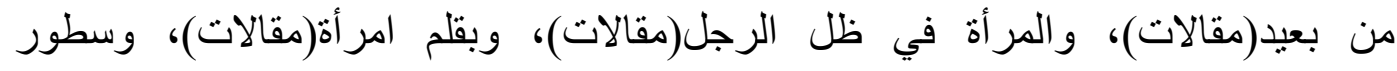
عذبة(مقالات).

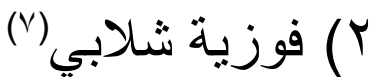

فوزية بشير شلابي، وُلات بطر ابلس في أوَل مارس 900 (م، وبها تلقَّت تعليمها إلى أن حصلت على ليسانس التربية في مجال الفلسفة و علم الاجتماع، من كلية التربية بجامعة الفاتح سنة .) $9 V \mathrm{~V}$

تكتب في مجال: الشعر، و القصة، و الرواية، و المقالة، و النقد، وقد نشرت نتاجها الأدبي

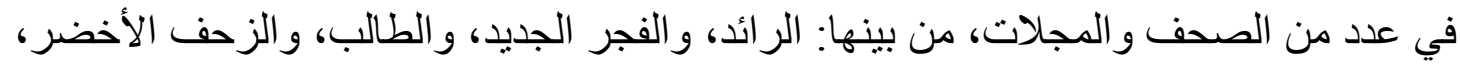

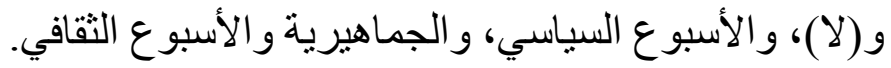

شاركت في عدد من الندوات والمؤتمرات الأدبية (القناة الأولى، و القناة الفضائية المصرية، وقناة راديو وتليفزيون العرب رقم (، ور اديو وتليفزيون العرب القناة العامة). نُشرت عدة مقالات وأبحاث حول إبداعها في صُحف ومجلات: الأسرار، والأهرام، الأه و أخبار الأدب، و المصور، و الكفاح العربي، و الجديد و الأسبوع الثقافي. حصلت على وسام الفاتح للإبداع في عيد الوفاء الأول عام 9 (م، وهي عضو روابطة الأدباء و الكتاب بالجماهيرية.

ا ـ قر اءات مناوئة(مقالات)، الدار العربية للكتاب، ليبيا، تونس، بره (م.

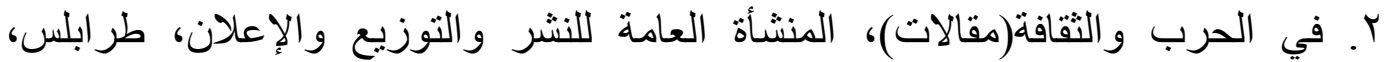
.م) $9 \wedge \varepsilon$

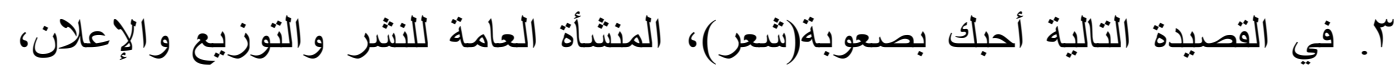
ع. صورة طبق الأصل للفضيحة (قصص قصيرة) المنشأة العامة للنشر والتوزيع

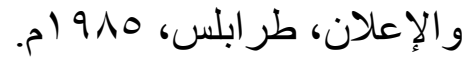




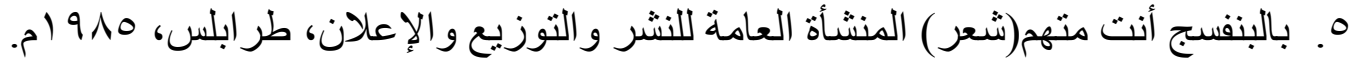

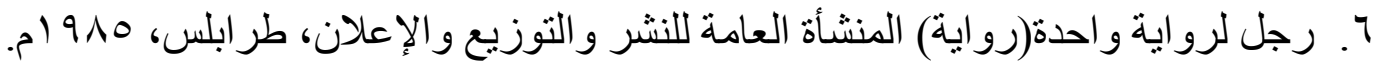

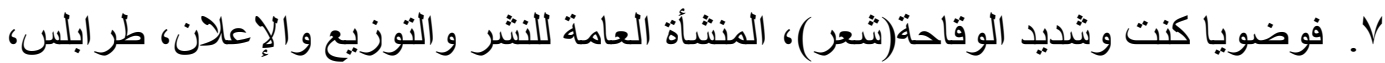

$$
\text { . م) } 910
$$

^. قراءات عاقلة جدًا (مقالات)، المنشأة العامة للنشر والتوزيع والإعلان، طرابلس، . 910 9 9. عربيدا كان رامبو (شعر)، المنشأة العامة للنشر والتوزيع و الإعلان، طر ابلس، 9191 ام.

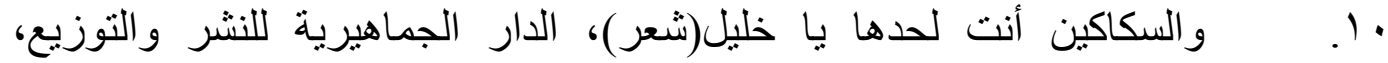
مصر اته، ليبيا، 71919 (م.

$$
\text { ولها كتاب مخطوط هو: (السينما و التغيير الاجتماعي). }
$$

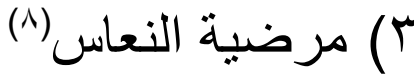

مرضية عبد الله النعاس ولات في بr يوليو 9 \ 9 في درنة، درست حتى السنة الر ابعة

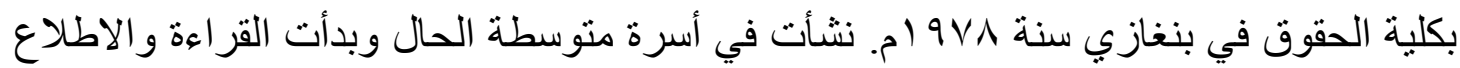
في وقت مبكر من حياتها، حيث كان و الدها بشجعها على تتمية مو هبتها في الكتابة.

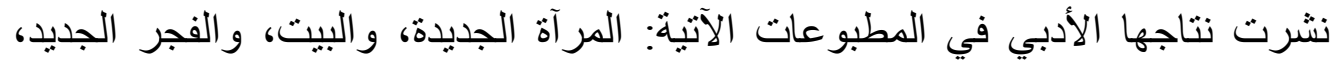

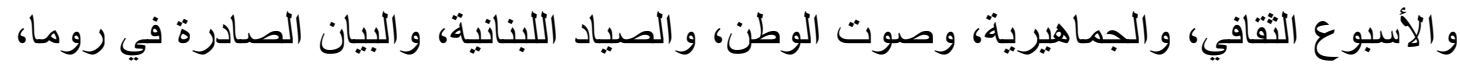
و الأمل الليبية.

وضمّت مجالات إبداعها: القصة، و الرواية، والمقالة، و الخاطرة، والتحقيق الصحفي، كما شاركت في بعض النشاطات المسرحية المدرسية ممثلة ومؤلفة. كتبت عدة برامج للإذاعة من بينها: من الصحافة إلى الميكروفون، وأسعد الأوقات،

$$
\text { وصباح الخير وأوراق الورد. }
$$

فازت بوسام الصحافة الأولى في ليبيا سنة ه 9 (1، حيث تولت أمانة تحرير مجلة البيت، والأمل، ونائبة لرئيس تحرير صحيفة البيان بروما.

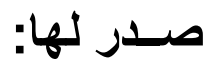

ا. رجال ونساء(قصص قصيرة)، الدار الجماهيرية للنشر والتوزيع والإعلان، مصراته،

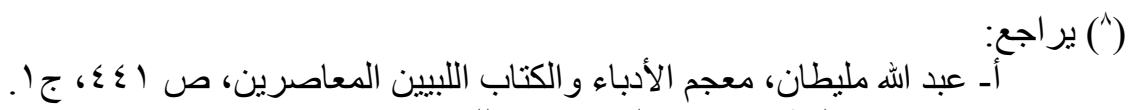




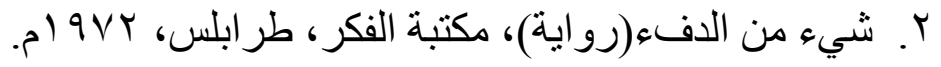

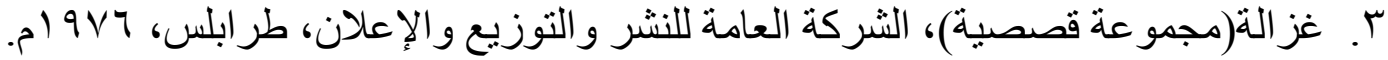

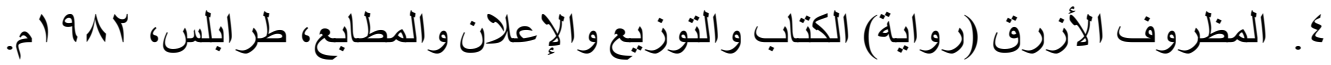
ومن أعمالها المخطوطة: "أنغام الملائكة"(قصص)، و"وجوه خارج الذاكرة"(رواية)، و "بنات داخلي"(رواية).

\section{ع ) نادرة العوبتي (9)}

نادرة الطاهر العويتي، ولدت في السابع من أبريل 9 \ أم بدمشق، ودرست حتى السنة

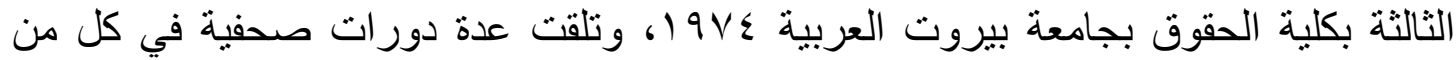
القاهرة وطر ابلس.

مارست العمل الأدبي من خلال مجلة البيت محَّررةً ومشرفةًَ على الأبو اب و الصفحات

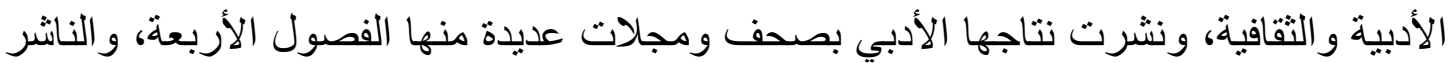

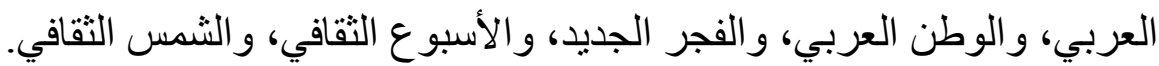
شاركت في عدة مؤتمرات أدبية في كل من: مصر، والجزائر، وتونس، والكويت، و العراق. وقد أجريت معها عدة لقاءات صحفية، وإذاعية منها: إذاعة صوت العرب، و إذاعة

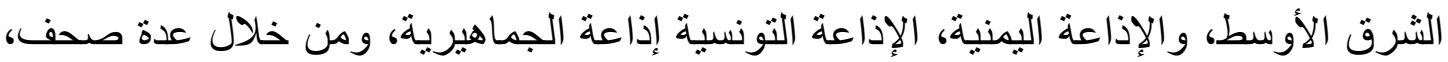
ومجلات الكفاح العربي، وصحيفة العرب، والبذاعة البيت.

ا ـ "المر أة التي استنطقت الطبيعة"(رواية)، المنشأة العامة للنشر والتوزيع و الإعلان، طر ابلس، . 911 ץ. "حاجز الحزن"(قصص قصيرة)، الدار الجماهيرية للنشر والتوزيع والإعلان، مصراته، .) $99 \leq$

؟. "اعتر افات أخرى"، الدار الجماهيرية للنشر و التوزيع و الإعلان، مصر اته، ـ9 99 ام.

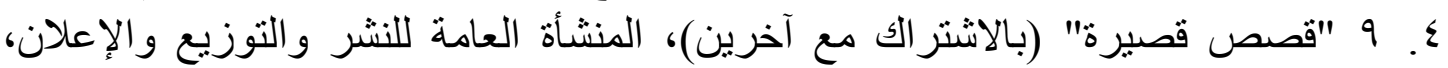

ومن أعمالها المخطوطة:مجمو عة قصص قصيرة. 


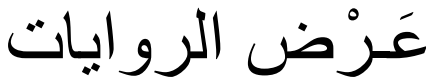

توطئسة:

يشهد الحقل السردي في ليبيا تناميًا ملحوظًا يحتاج إلى رعاية على المستوى المجتمعي

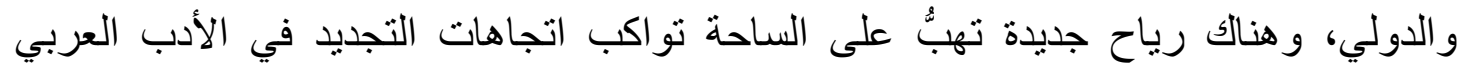

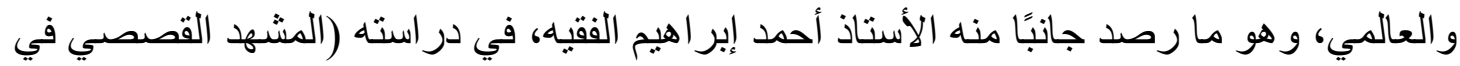
لليبيا: ملاحظات حول القصة الليبية القصيرة)( • (1)، التي قدمها لمناسبة انعقاد ملتقى القاهرة

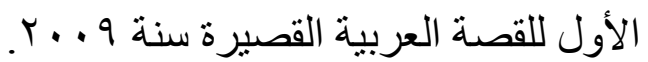

جدير بالذكر أن تاريخ كتابة جميع الروايات النسائية موضع الدراسة كان ما بين عام

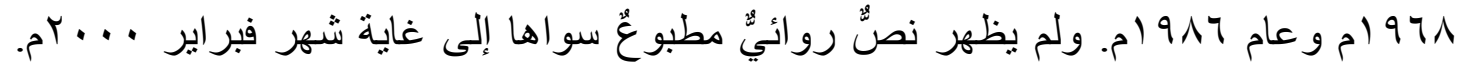
و هذا ما جعل الدر اسة مقتصرة على ستة نصوص رو روائية فقط.

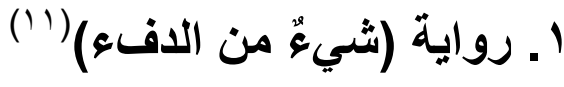

تُنْنَردُ أحداثُ هذه الرواية على لسان البطلة "أمل" الموجودة ببيتها مع زوجها و ابنها،

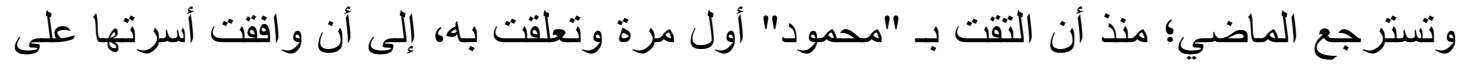

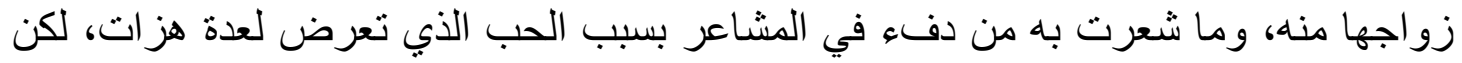

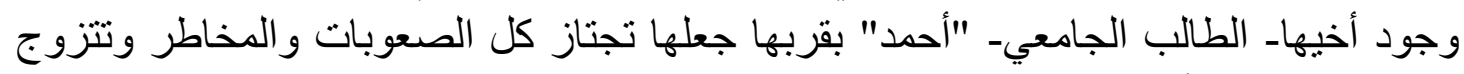
ممن اختارته شريكًا لحياتها.

و البطلة طالبة بالمرحلة الثانوية، كانت تتميز بتفوقها في در استها، وو عيها بو اقع المر أة خاصة والجيل الجديد عامة، في مواجهة الانغلاق الاجتماعي، ويلاحظ أنه لا يوجد تأزم للأحداث، ولم تكن هنالك ذروة للرواية أو كما بصطلح عليها: عقدة؛ إذ إن المعاناة النفسية للبطلة الانة

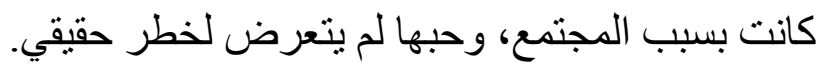

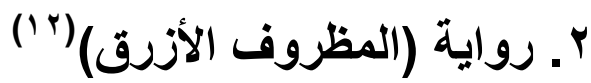

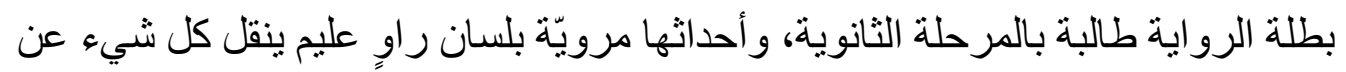
تللك البطلة، و هي تتفق مع سابقتها- في الرواية الأولى لنفس المؤلفةـ بأنها متفوقة في الدرانة استة

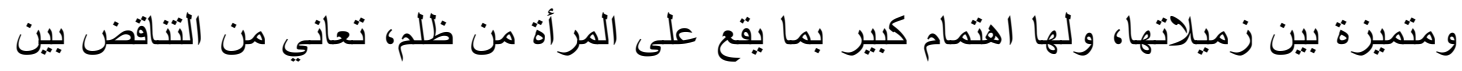

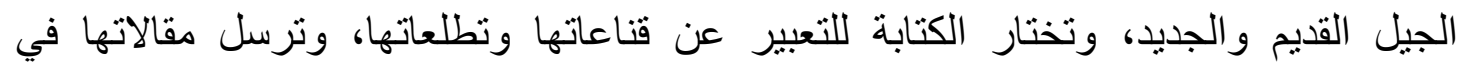

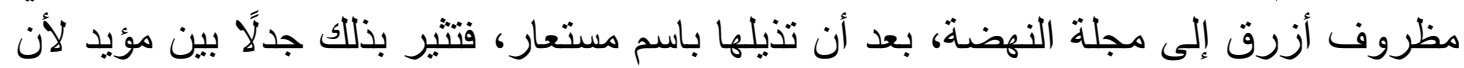

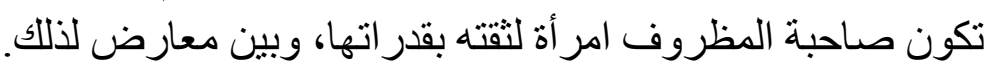

(·) (المشهد القصصي العربي: طبعة تجريبية بمناسبة انعقاد ملتقى القاهرة الدولي الأول للقصة العربية

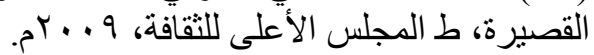

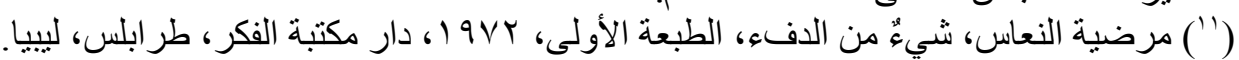

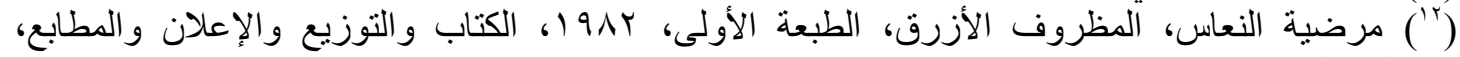


تنشأ علاقة حب بين البطلة ورئيس التحرير، وتتطور الأحداث إلى أن تبلغ ذروتها في

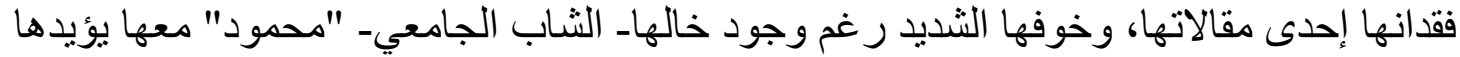
ويشجعها، وتنتهي الرواية بإفصاح زينب عن اسمها وتصميمها على مواجهة المجتمع إلى جانب معهي حبيبها مصطفى.

و تكاد الرو ايتان تتطابقان لو لا بعض التعديلات في الرو اية الثانية أهمها:

الإشارة إلى الإطار التاريخي، حيث يوجد من الإشارات ما يُمكَّن القارئ من استنتاج أن الأحداث تدور في فترة الستينيات. إضافة بعض القضايا الأخرى مثل فساد المؤسسات الرسمية الحيوية كالمستشفيات، ومصادرة حرية الر أي وحق النقد. إضافة مسألة العلاقة بالكتابة بالنسبة إلى البطل و البطالة"(ب آ) حيث كان مصطفى رئيس

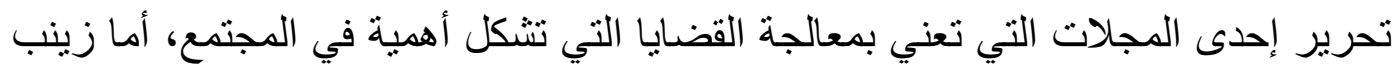
فهي مر اسلة مو اظبة بكتابتها الو اعية التي تناقش قضايا المر أة، و إن كان ذلك باست الجم مستعار.

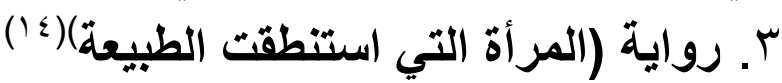
تدور أحداث هذه الرواية حول العلاقة بين الرجل و المر أة، وبطلتها فتاة على أعتاب التخرج،

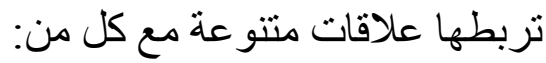

هالأرض و الطبيعة، وهما تشكلان لها مصدر أمان، ومكانًا تهرب إليه كلما ضاقت بها السبل.

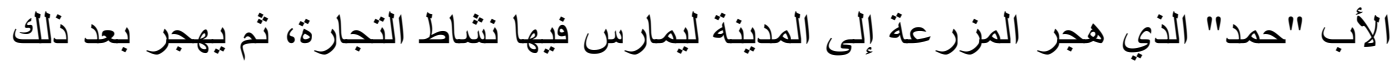

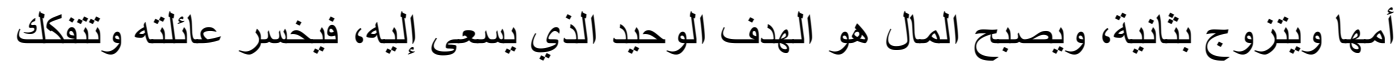

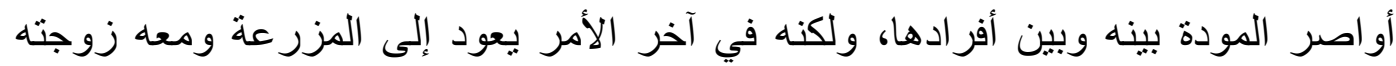

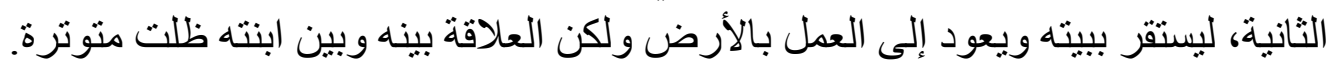

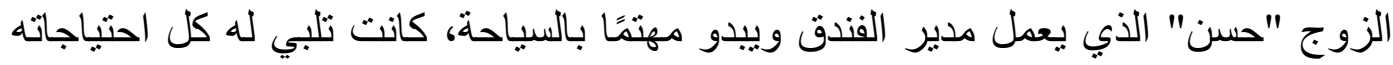

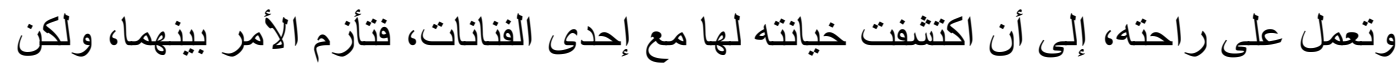

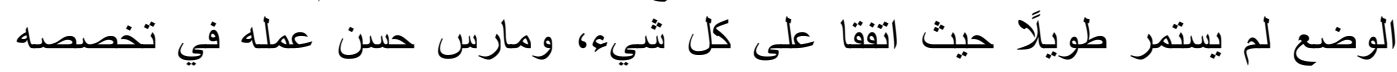

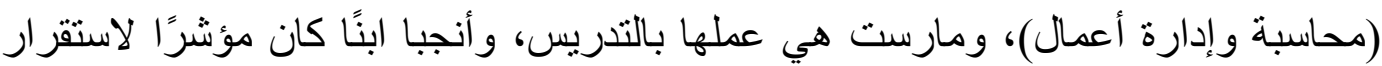
حياتهما الأسرية. الأم "مبروكة"، التي تحملت ظلم و الدها دون أدنى اعتر اض على تصرفاته، وهي تحبها

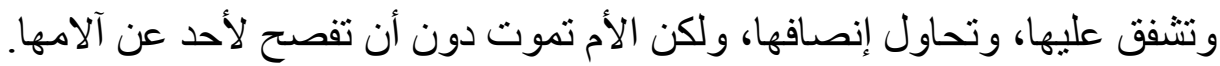

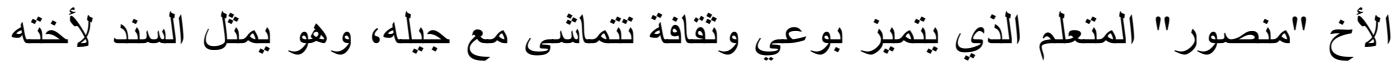
نعيمة، حيث إنه الأقرب إليها.

\section{ع. رواية (رجل لرواية واحدة)(10)}

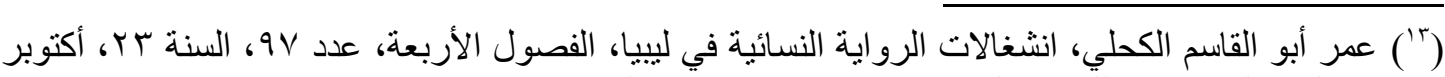

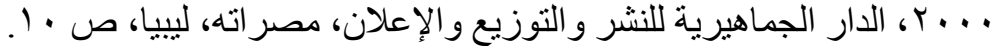

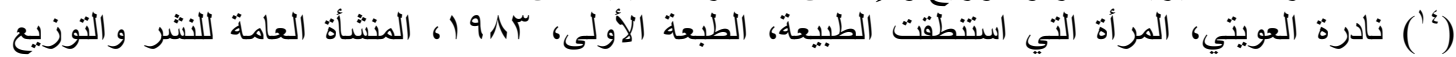


بطلتها امرأة مثققة ثُدعى: صالحة، "تطل بنا على عالم الرجل بذكاء فهي تحلل أفعاله

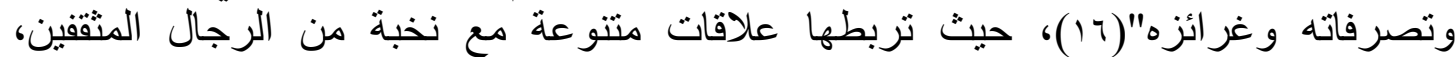

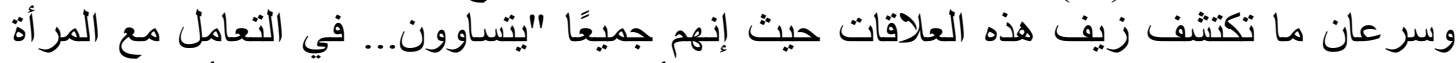

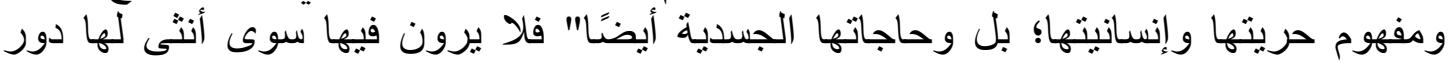

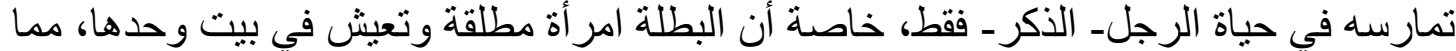

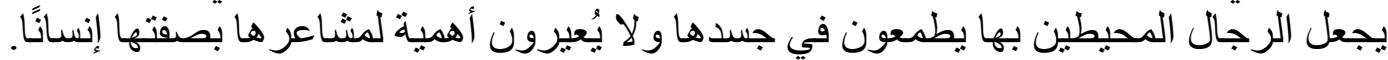

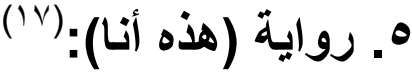

تتمحور حول العلاقة بين الرجل و المر أة، سواء أكان أبًا أم زوجَا، وتنقل البطلة (عفيفة) أهم

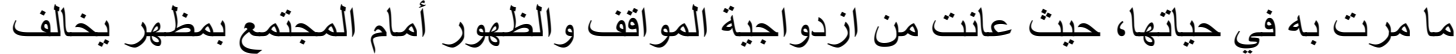

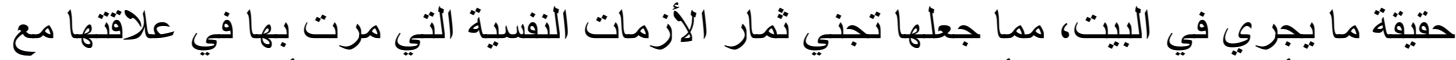

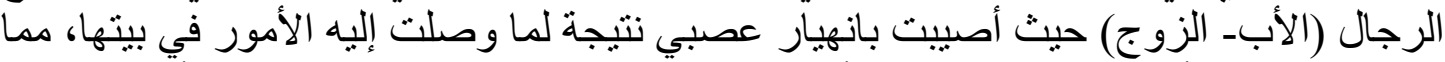

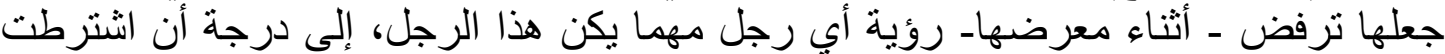

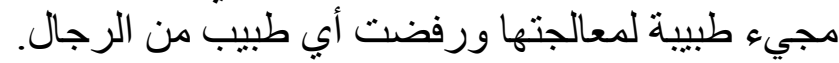
و الرواية عبارة عن استرجاع للأحداث منقسم إلى قسمين:

الأول بُعْنَي بعلاقة الو الد ببناته وزوجته ويتم فيه استخدام ضمير المتحدث المفرد.

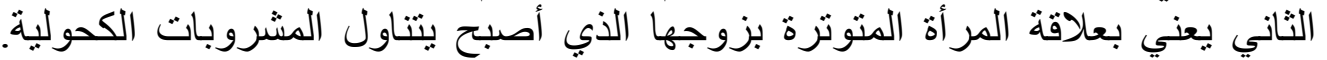
وفي هذا القسم يبدأ التقديم باستخدام ضمير الغائب، ثم ضمير المتحدث المئ المفرد.

7.

تبدأ أحداث الرواية في الطائرة حيث تنطلق البطلة في سرد حكايتها، لتنتهي وهي في بيت أسرتها تقرأ رسالة اليهودي "سيمون" الذي يعترف بأنها قد تركت في حياته بصمات، و البطلة

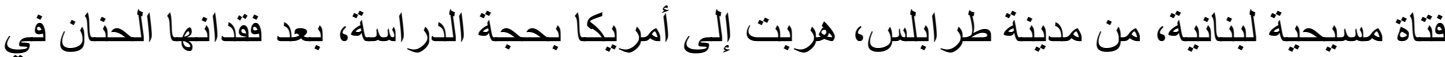
الأسرة، و الحرية في المجتمع، وبعد فنشها في قصة حب من من طرف ولفينة واحد، والرواية في مجملها تصف مظاهر من العلاقة بين الجنسين من جهة، وبين العرب و اليهود من جهة ثانية.

وتتميز النصوص الروائية النسائية ـ في مجملها ـ بأنها ركزت على المرأة وجعلت منها ومن مشاكلها محورًا للأحداث، فكانت المرأة هي البطلة، وكان الرجل مساندًا لها أو معارضًا

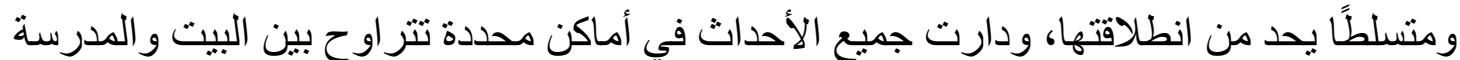

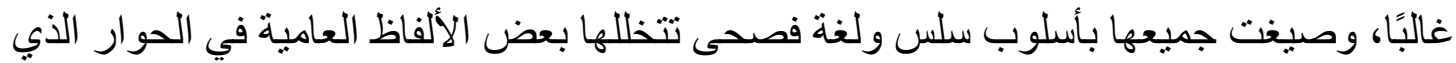

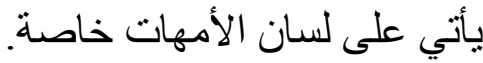

و هذه النصوص الروائية هي المؤشر الحقيقي لمعرفة مدى تطور الأدب النسائي بليبيا.

(10) فوزية شلابي، رجل لرواية واحدة، الطبعة الأولى، 910 1، النشأة العامة للنشر والتوزيع والإعلان، طر ابلس. (") فاطمة سالم الحاجي، قر اهة نقدية في رواية رجل لرواية وائل واحدة للأديبة فوزية شلابي، الفصول الأربعة،

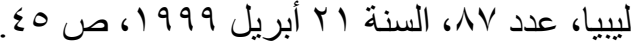

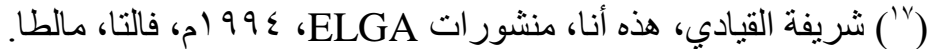
(1^) شريفة القيادي، البصمات، منشور ات ELGA، 999 (م، فالتا، مالطا. 


\section{إشكالية مصطلح الأدب النسائي}

توطئة :

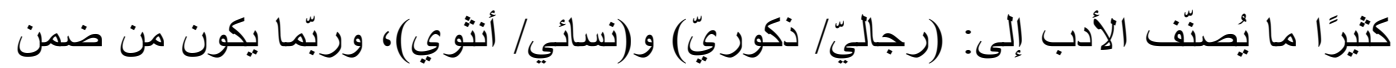

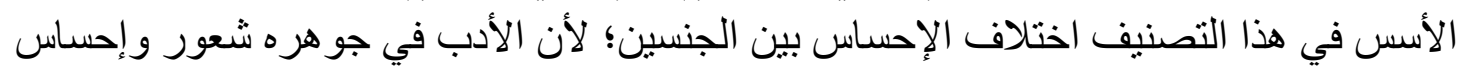
يصاغ شعرًا أو نثرًا.

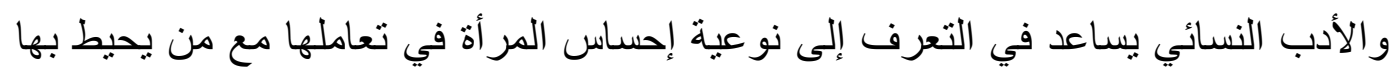

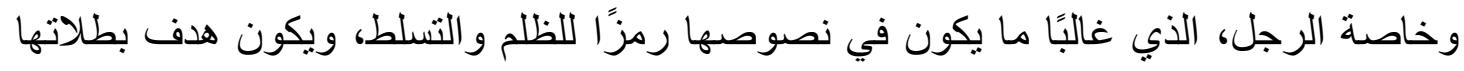

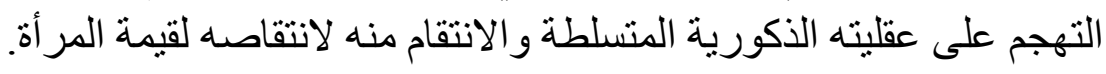

وحسب ما ذهب إلبه الأستاذ الدكتور محمد عبدالمطلب؛ فإن الوعي بمفهوم النسوية الذي ظهر

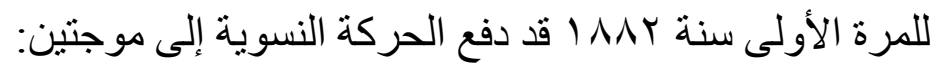

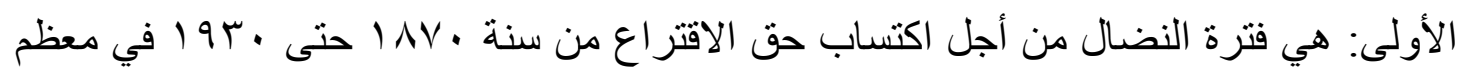
الديمقر اطيات الليير الية الغربية.

و الأخرى: هي فترة الثورة الثقافية النسوية بعد سنة 1971 .

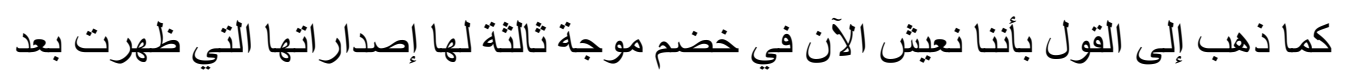

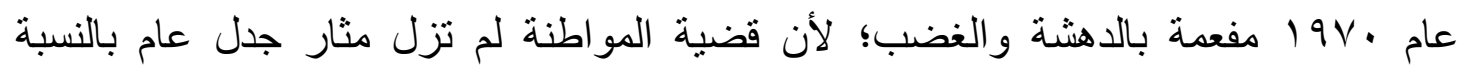
لألمر أة(19) (19)

إثكالية المصطلح و اختلاف التعريفات:

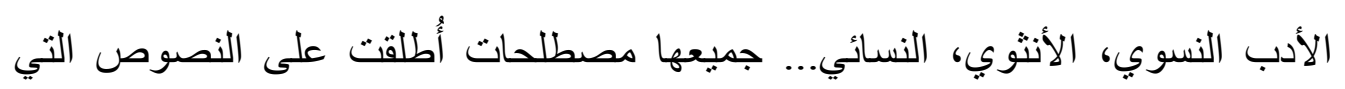

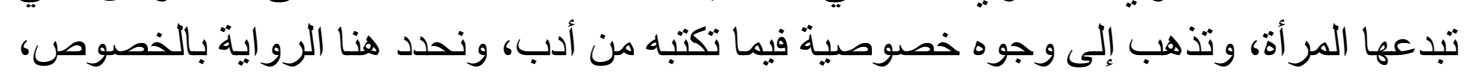

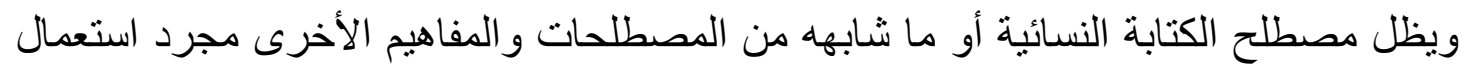
إجر ائي تقتضيه ظروف التعريف بأي أدب تنتجه أقلية.

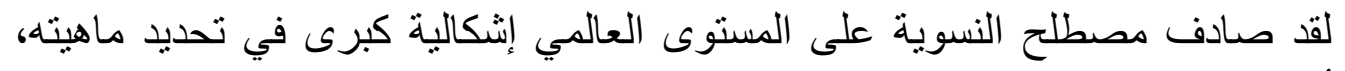

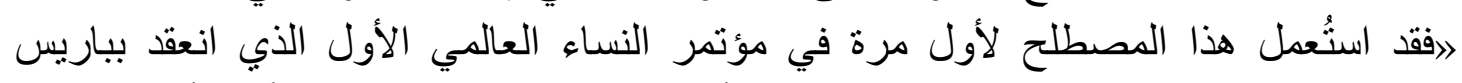

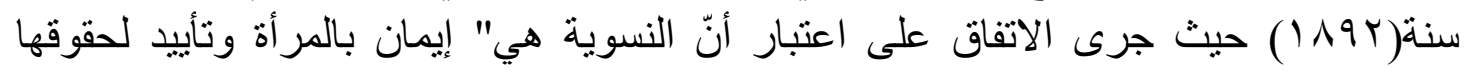

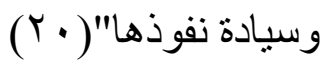

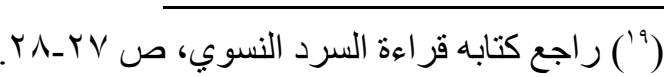

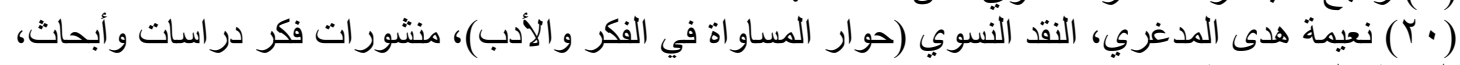

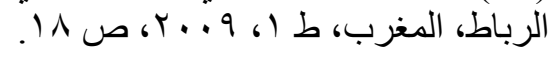




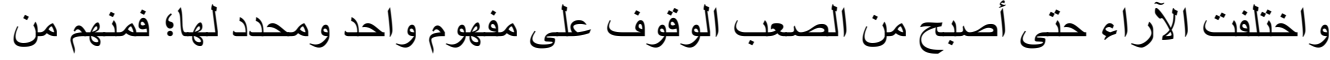

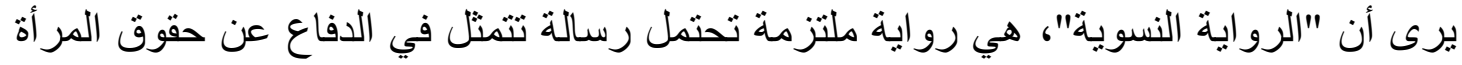

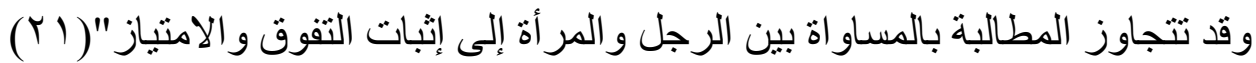

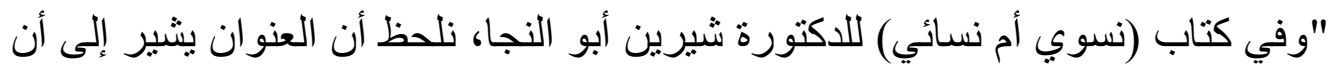

هناك فرقًا بين المصطلحين، وقد أشارت الكاتبة إلى ذلك عندما لاحظت أن أن (النسوي) يتجه إلى إنى الوعي الفكري و المعرفي، وأن (النسائي يتجه إلى الجنس البيولوجي. إذ تؤكد في مقدمتها أنه

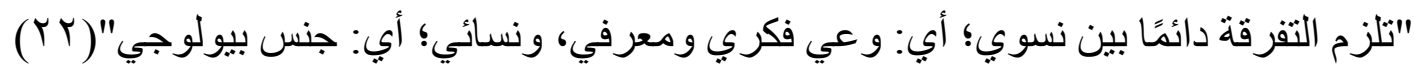

ومنهم من يرى أن الرواية النسوية هي "التي تحقق كثف وإزاحة عناصر المنظور

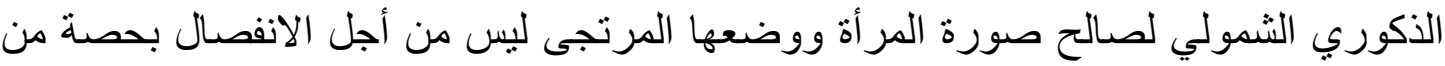

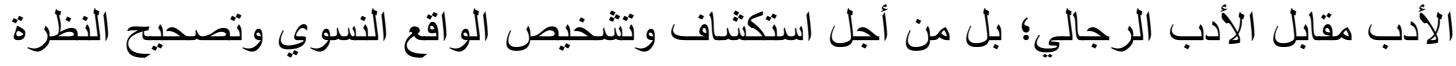

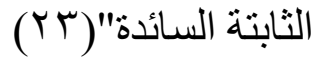

ومنهم من يعرف النص النسوي بأنه: "النص الذي يأخذ المر أة كفاعل في اعتباره، و هو

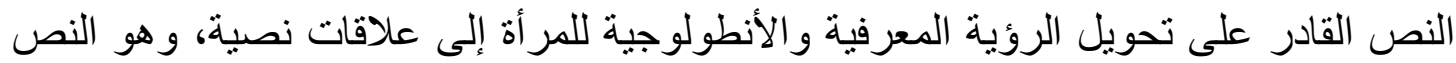

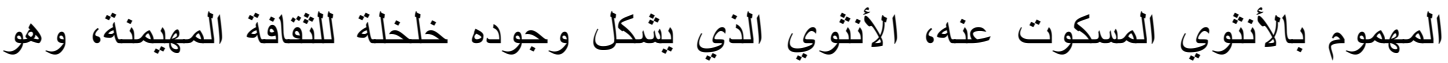

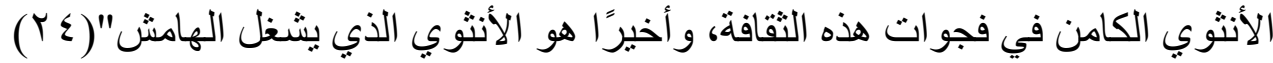

ومنهم من يرى أن الرواية النسوية هي "التي تحقق كثف وإزاحة عناصر المنظور

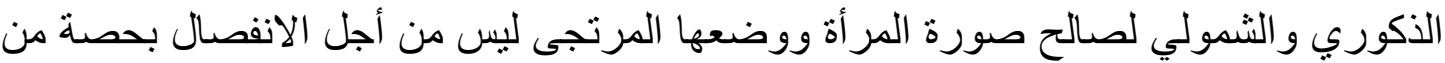
الأدب مقابل الأدب الرجالي؛ بل من أجل استكثاف وتشخيص الواقع النسوي وتصحيح النظرة النّا

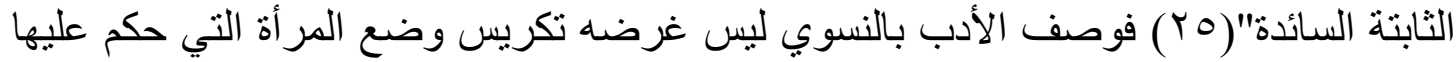
المجتمع بالجمود في صورة ثابتة لا تتعدى حدود الطاعة وتلبية أوامر الذكور، وليس هدفه أيضًا

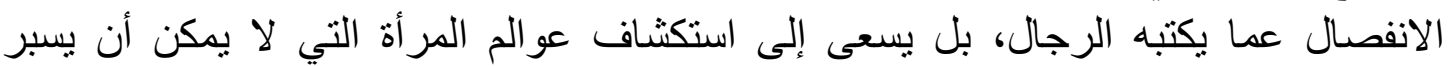
أغو ارها سو اها.

"يبدو أن الاختلاف حول المصطلح في المفهوم و المرجعية قد دار حول أربع دوالّ هي

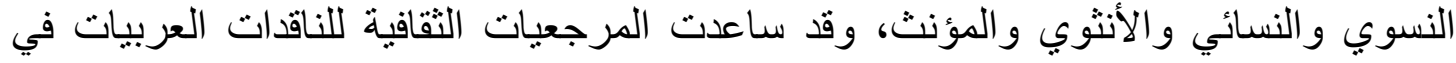
ضبط هذا المصطلح وتحديده معرفيًا، لكن هذا التحديد لم يعتمد الأساس اللغوي في المعجم العربي، فنجد مثلًا- زهرة الجلاحي في در استها (النص المؤنث) تقدم مصطلح (النص المؤنث)

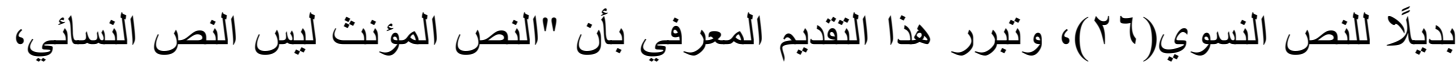

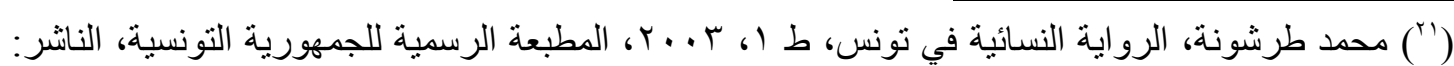

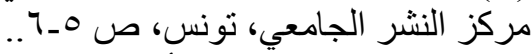

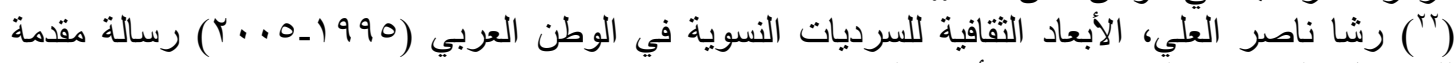

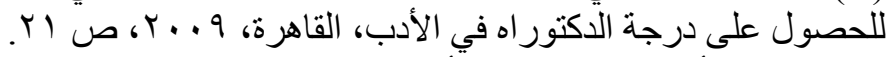

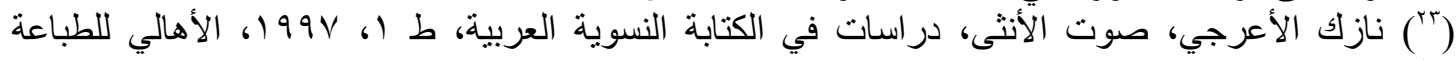

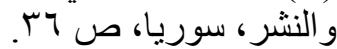

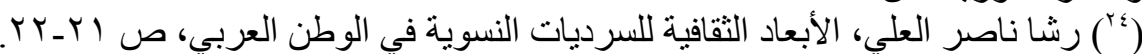
(Y)

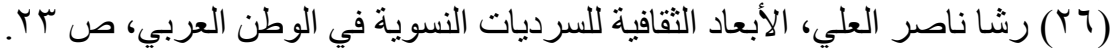


ففي مصطلح نسائي معنى التخصيص الموحي بالحصر والانغلاق في دائرة جنس النساء، بينما

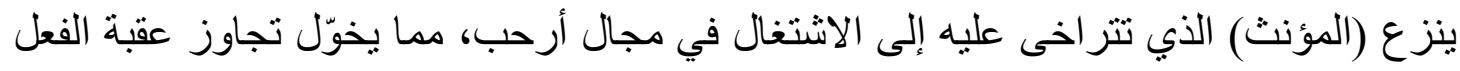

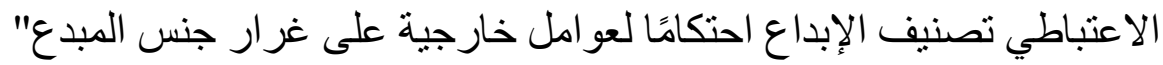

ويؤكد ذللك أحد النقاد الذي يرى "أننا أصبحنا مع هذا الإبداع النسائي ننظر إلى أنفسنا

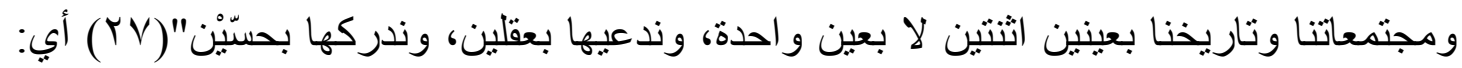

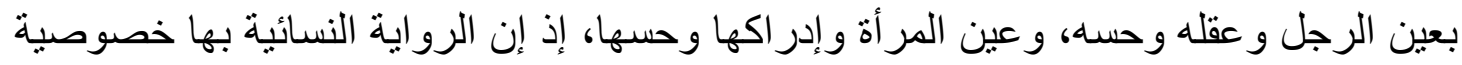
تختلف عن باقي الروايات. و إجمالًا فهناك تعريفاتٌ متعدِّدة للأدب النسوي، أثنهر ها: الأعمال التي تتحدَّث عن المر أة، وتلك التي تُكتَب من قِبِل مُؤلتِّات.

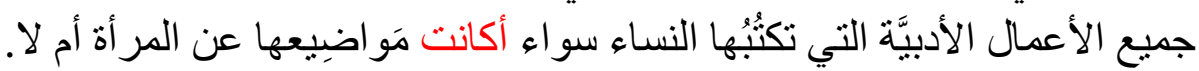

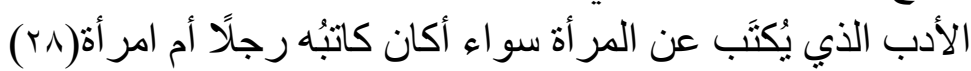
اختلاف المو اقف من الأدب النسائي: تختلف المواقف من وجود خصائص تميز الأدب النسائي، وقد تباينت آراء المرأة الكاتبة حول هذا الموضوع: عو

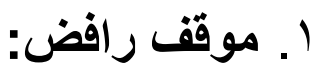

حيث إن بعضهن يرفضن هذه التسمية بحجة أن للأدب قيمة إبداعية و لا يقبل التقيم

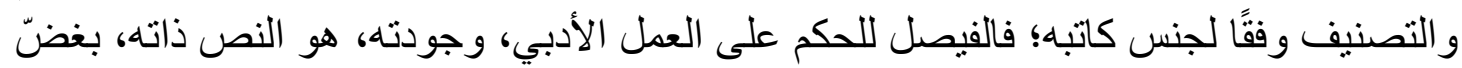

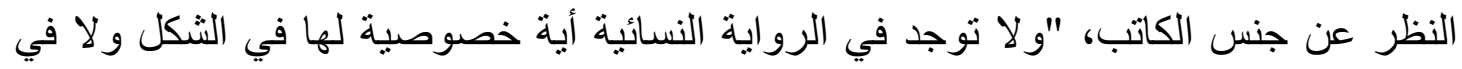

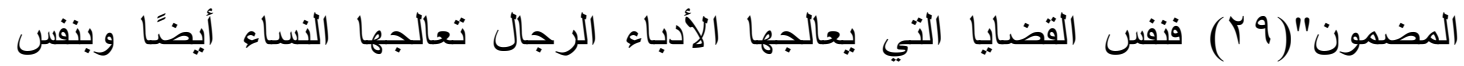
الأسلوب.

ومن أهم من يمثل هذا الموقف: الأستاذة لطيفة الزيات التي أكَّدت على مذهبها في عدم تخصيص أدب للمر أة رغم إقرار ها باختلاف الكتابة بين المر أة و الرجل، تقول: "لقد رفضت دأت دائمًا

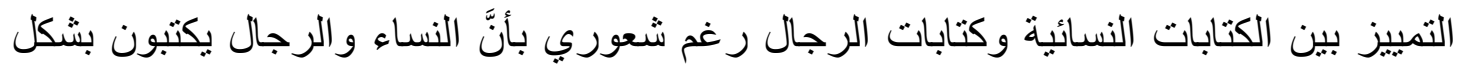

مختلف"( • (ب)

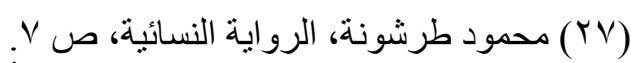

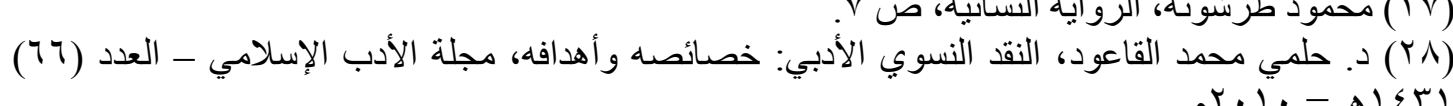




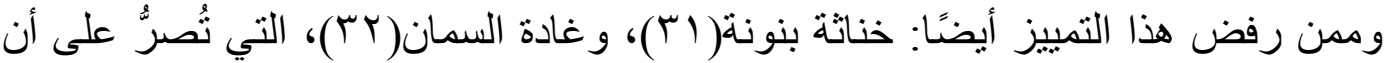

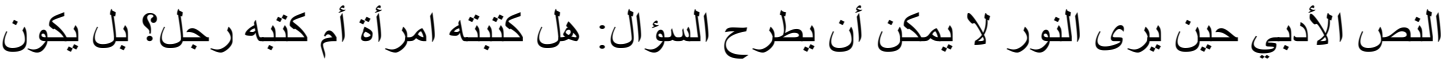

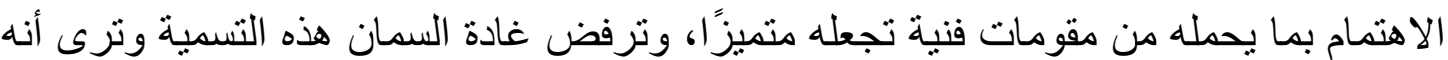

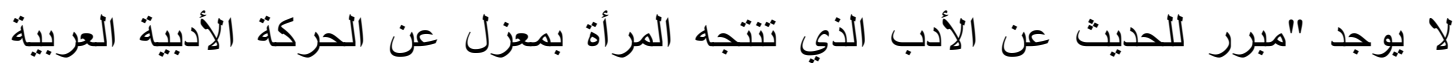

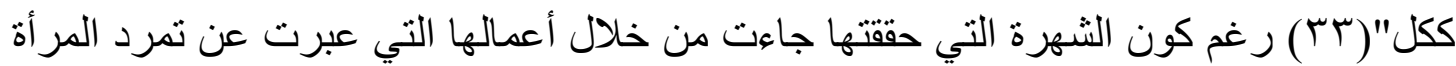

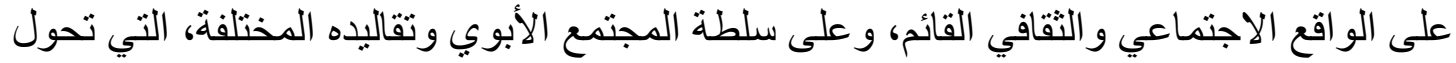

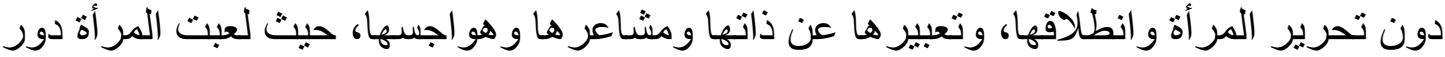

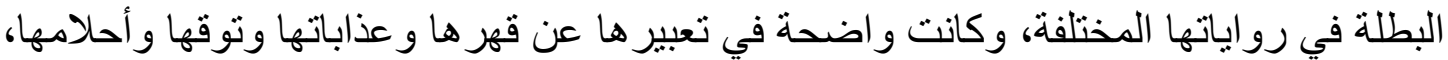

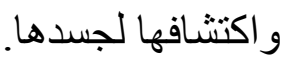

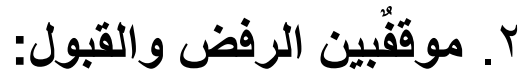

تمثل في الوسطية، "ويرى أن الخصوصية أمرٌ طبيعيّ لكنها لا تمنع من معالجة قضايا

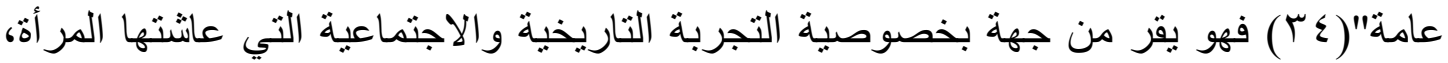
وجعلتها أسيرة شرطها، ومن جهة أخرى يرفض أن أن تكون هذه الخصوصية نابعة من خصوصية الخية

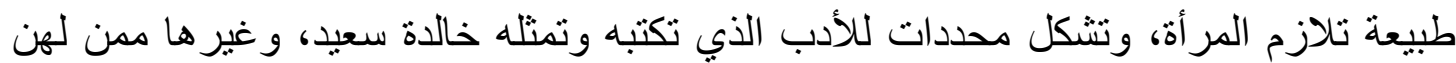
نفس القناعة، وكان الاعتر اف بهذا اللون من الأدب مؤقتًا.

\section{r. موقفت يُقْرٌ بوجود الأدب النسائي:}

وهو "يعتبر الرواية النسائية رواية أقلية مجتمعية كغيرها من الأقليات؛ فلابد من التعبير

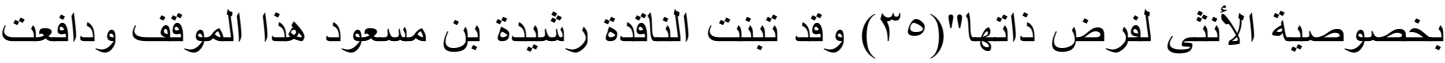

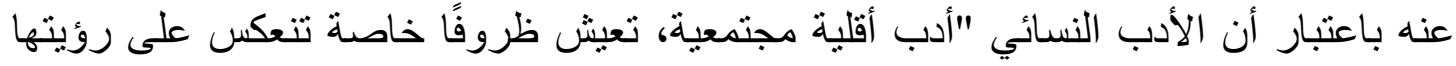

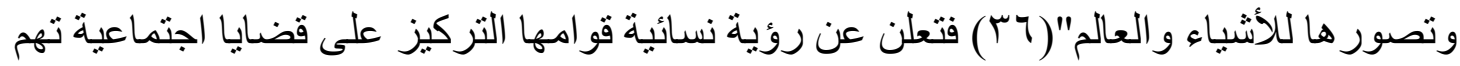

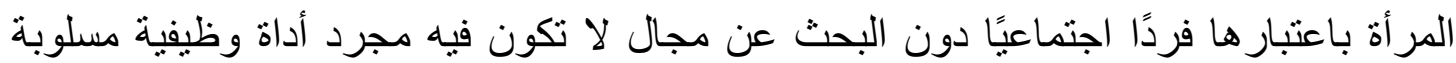

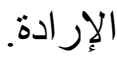

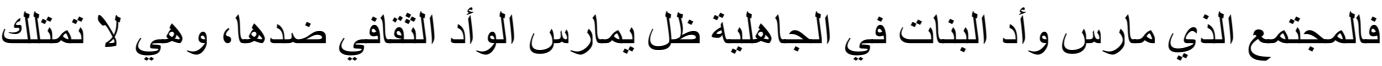

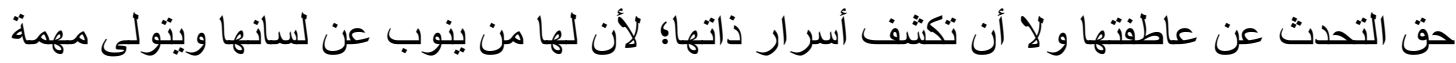

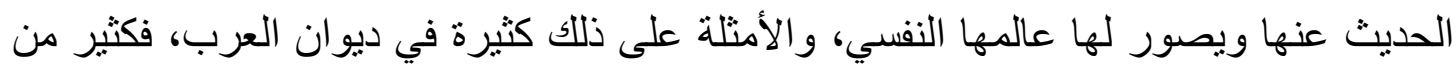

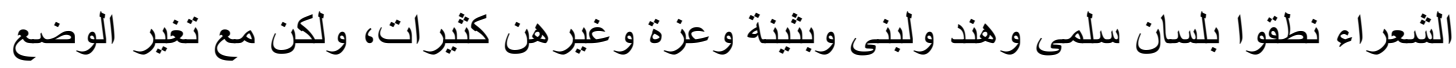

(ابr) ينظر: بوشوشة بن جمعة، الرواية النسائية المغاربية، طا، أبريل ץ...r، المغاربية للطباعة والنشر

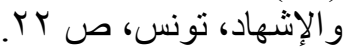

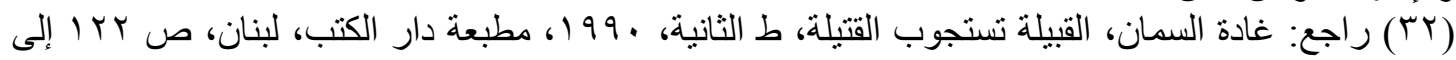

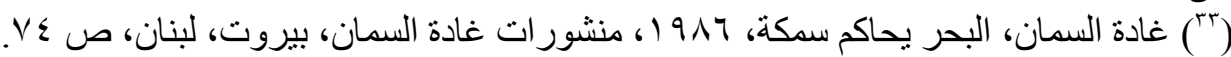

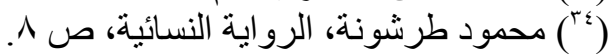

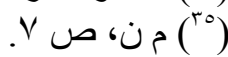

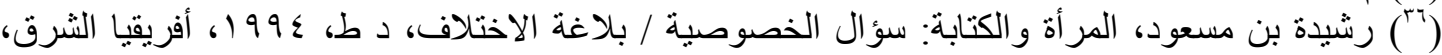




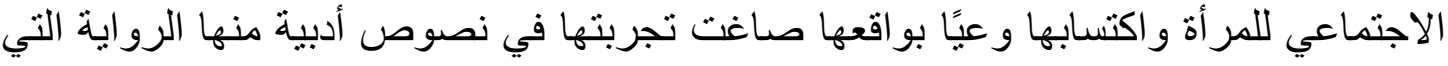

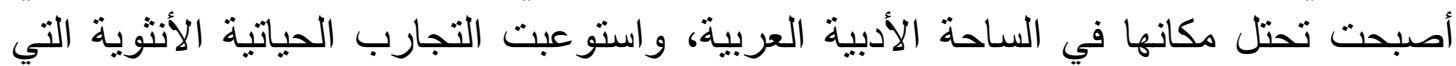
نعايشها النساء.

وجميع هذه التقسيمات ما هي إلا تسميات إجرائية الهدف منها نسهيل دراسة النصوص

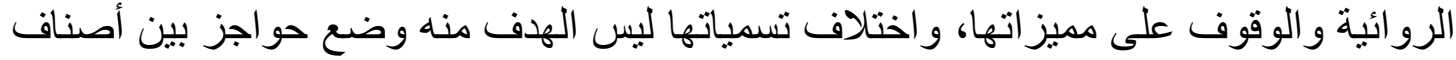

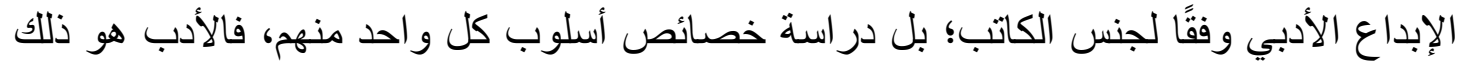

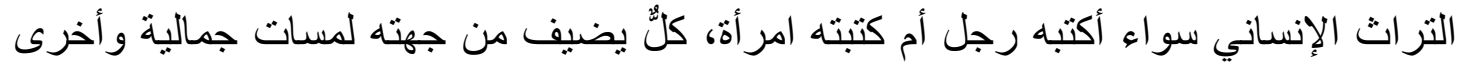

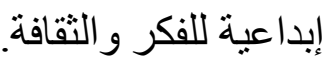

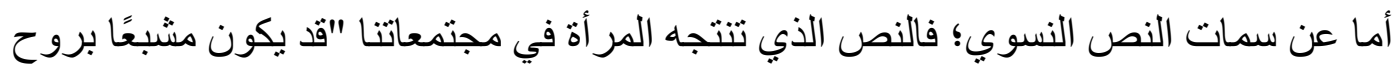

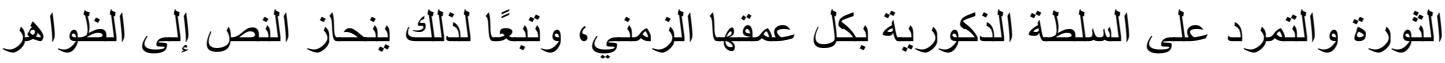

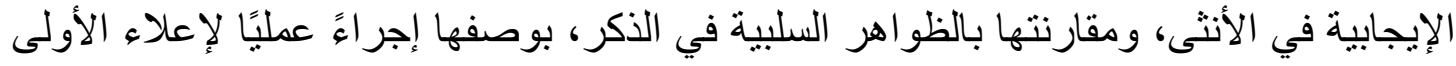

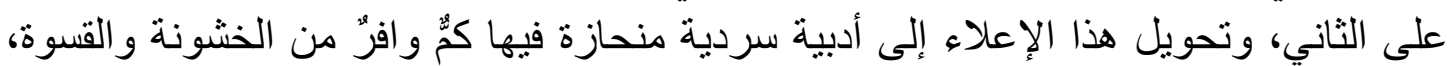
رغم أنها تعتمد ردود الأفعال أكثر من اعتمادها الألفاء الفعال ذاتها"(rV)

و الحقيقة أن ما ذهب إليه بعض الباحثن في هذا الإطار حريٌّ بالإشارة والإثبات هنا، فقد

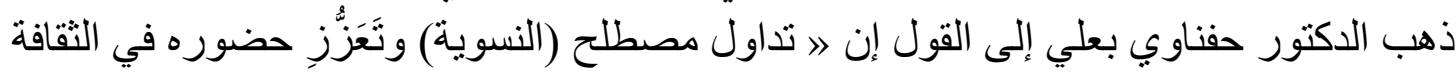

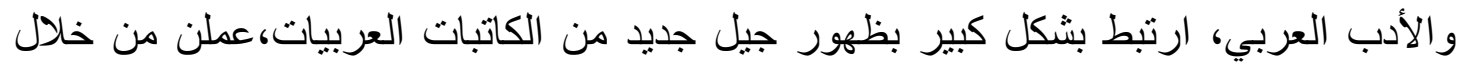

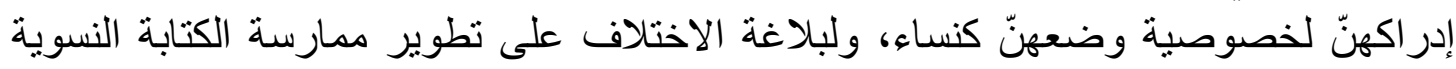

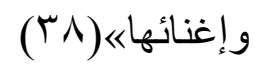

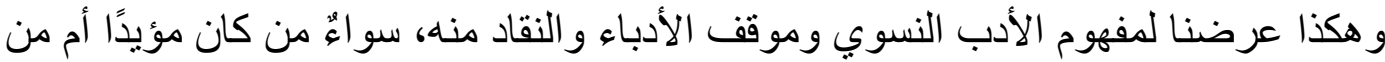

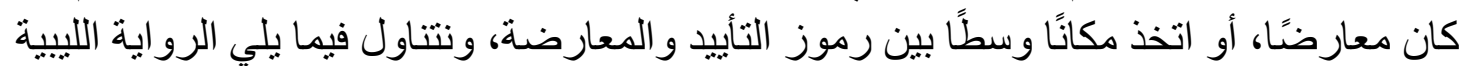

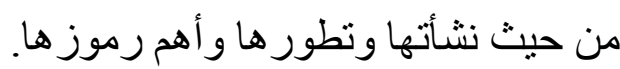

بدايات الرواية اللبيية (ظروف نشأة الرواية في ليبيا) تعريف الرواية:

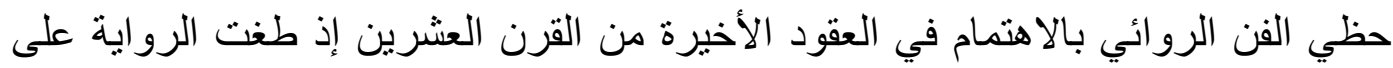

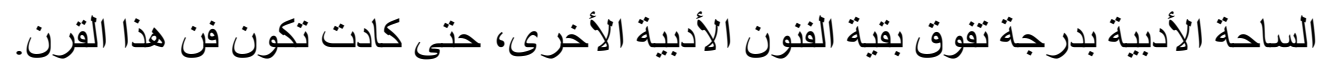
وقد تعددت تعريفاتها، وهي تدور في مجملها على أن الرواية نوع من أنواع الكتابة القصصية النترية، تتصف بالطول، و الخيال، و الاعتماد على السرد. 


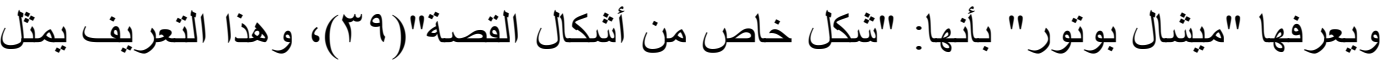
خصوصية من خصوصيات الرواية، حيث يربطها بالحكي، ويقول إن الأساس الأول الذي تقوم

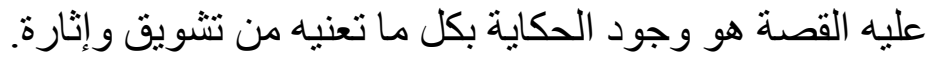

$$
\text { أما "رولان بورتوف" فيكتفي بالقول: "الرواية هي سرد"( • ) }
$$

ويقصد بالسرد من حيث دلالته اللغوية شدة الإحكام والإتقان، وقد استمد منه التعريف الاصطلاحي الخاص بالرواية؛ إذا أردنا التعبير عن الإخبار والحكي؛ إذ إن الإنهات الحكايات تحكم

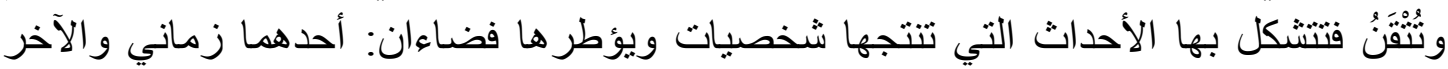
مكاني، وفقًا لبناء وتسلسل يختار هما الكاتب.

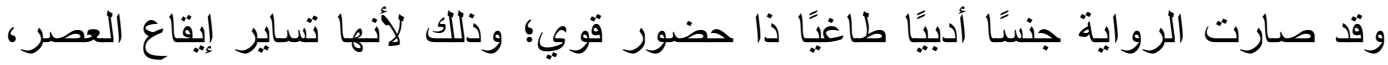

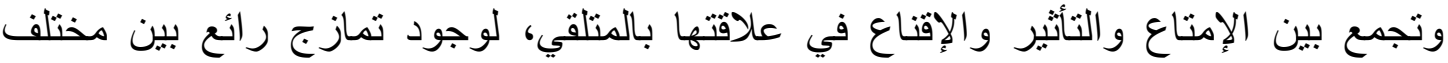

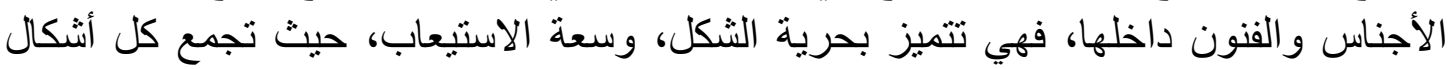

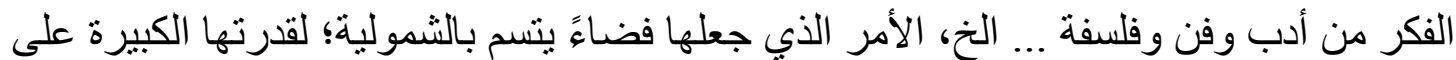

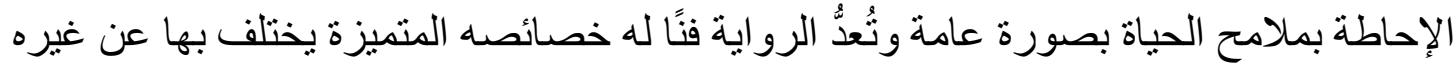
من الفنون الأخرى، ويمكن ملاحظة ذللك من خلال الوقوف على مدلولها القائم على "سرد

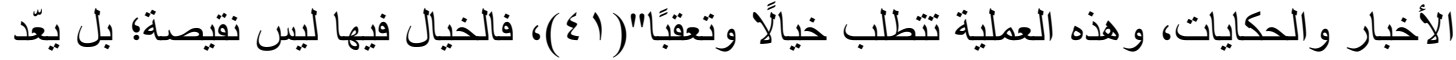

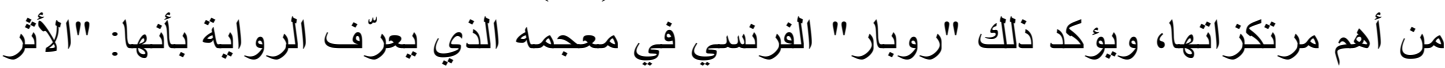

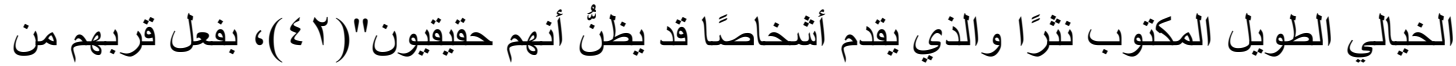

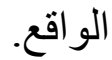

ورغم تنوع التعريفات الخاصة بها إلا أن أشملها التعريف القائل بأنها: "حكاية نثرية

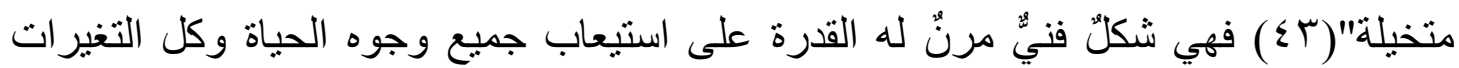

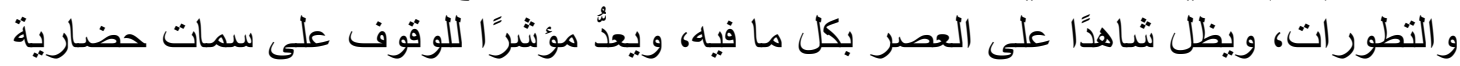
تميزت بها فترة ما من تاريخ دولة معينة.

ومنهم من يعرفها بأنها "فن الثخصية" أي الفن الذي يقدم تجربة إنسانية من خلال تصويره

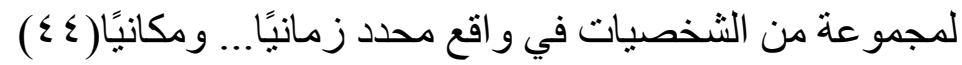

(بqج) بحوث في الرواية الجديدة، ترجمة: فريد أنطونيوس، سلسلة زدني علمًاء منشورات عمويدات، بيروت،

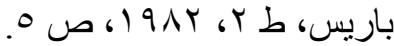

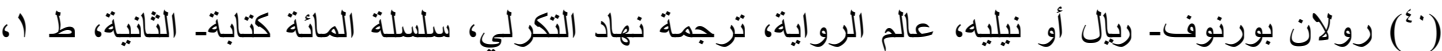

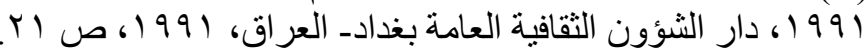

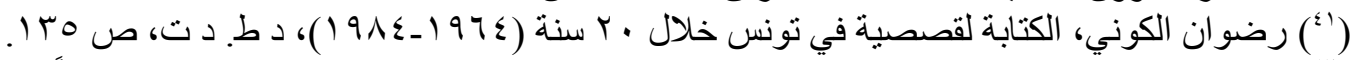

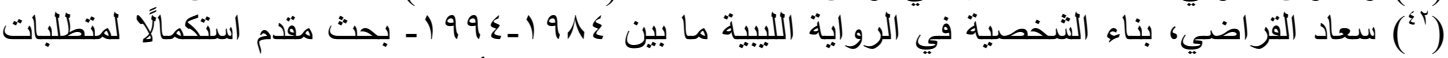

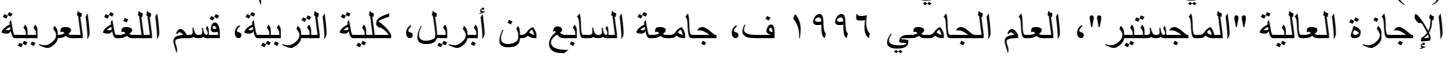

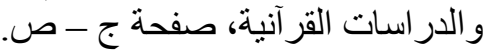

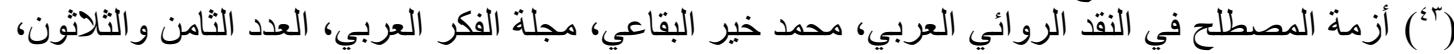

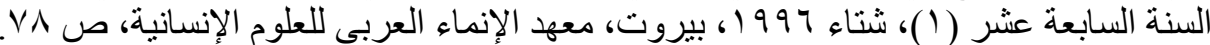

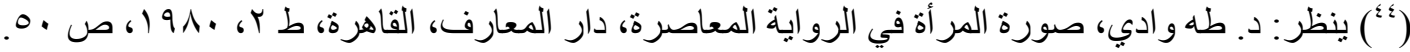


إن الرواية قصة طويلة تتضمن أحداثًا وأثخاصنًا، وتدور في إطار من الزمان و والمكان، وفيها

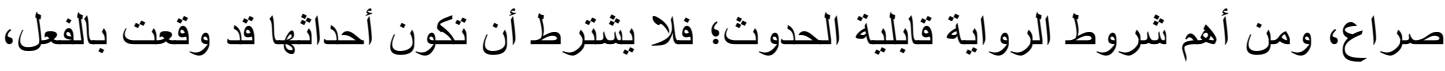

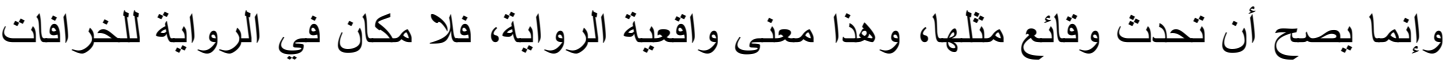
و الأساطير التي كانت تثميز بها الحكايات التر اثثية القديمة.

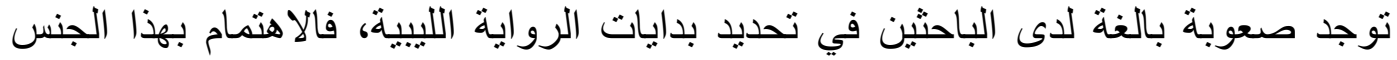

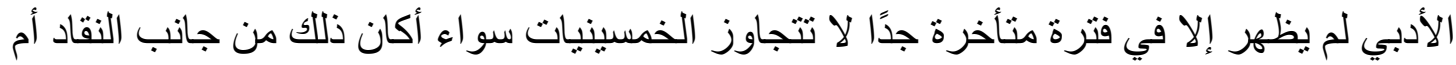

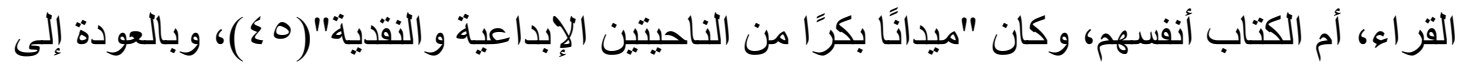

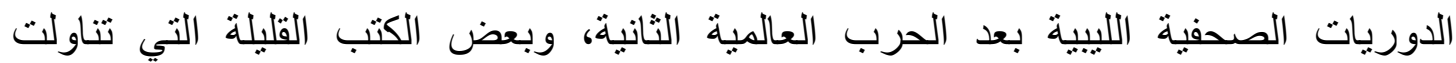

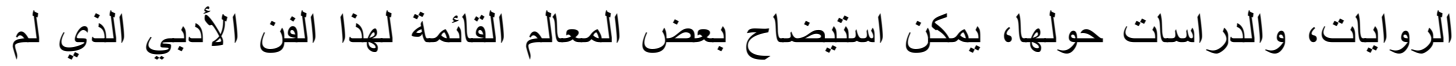

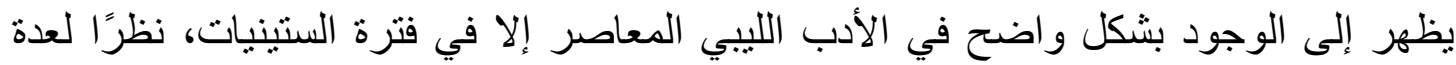

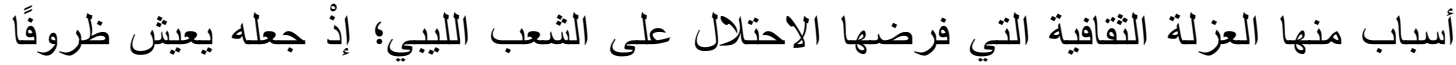

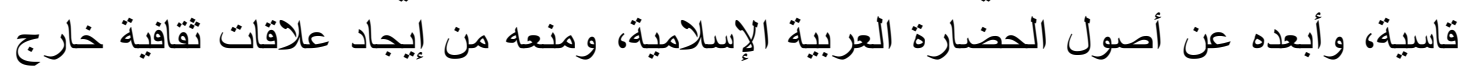

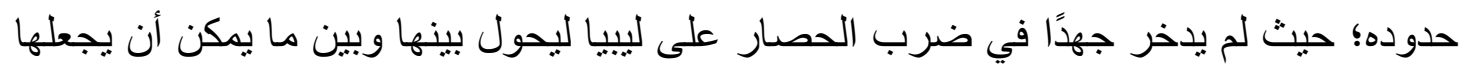

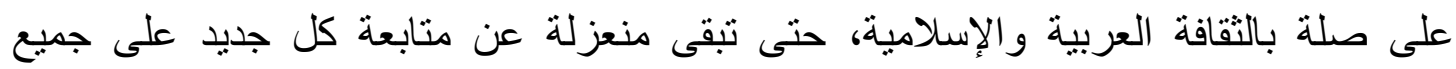

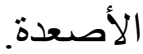

عانى الليبيون كثيرًا من الحصار الثقافي الذي ارتبط بالاحتلال الإيطالي، فكلما ذُكر هذا

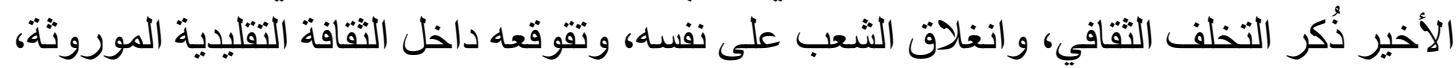

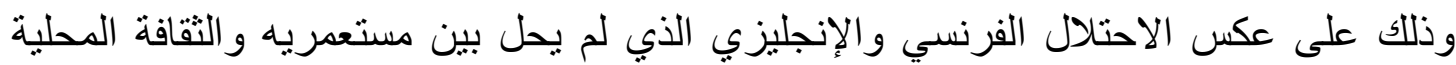

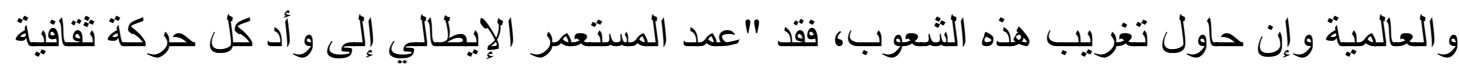

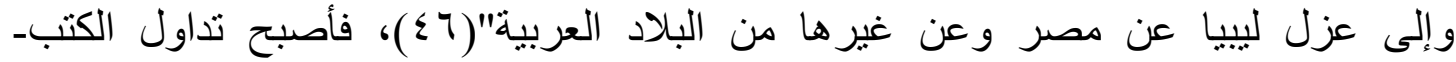

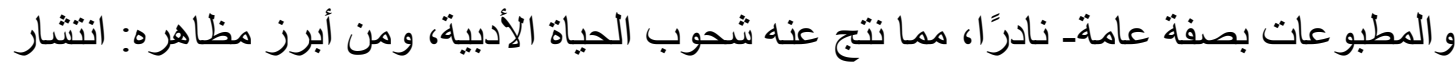

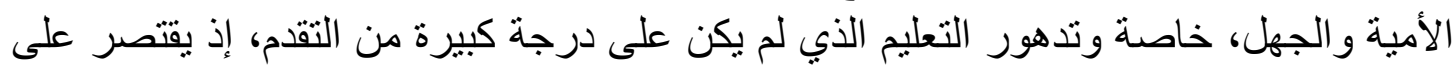

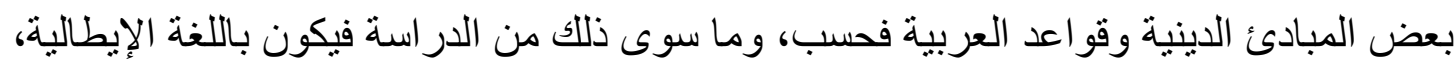

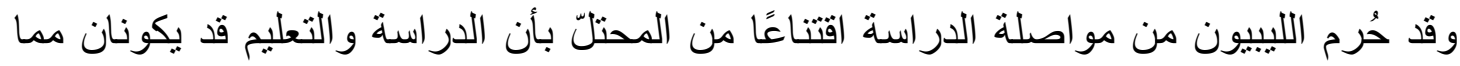

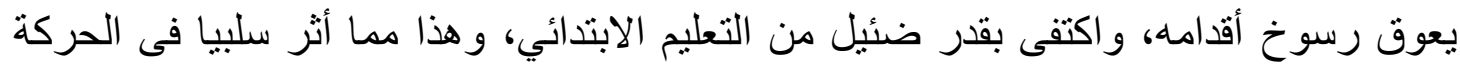

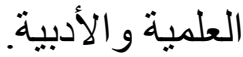

كما عانى أبناء الثعب الليبي من الفقر والمجاعة إضافة إلى الجفاف، وانتشار الأمراض

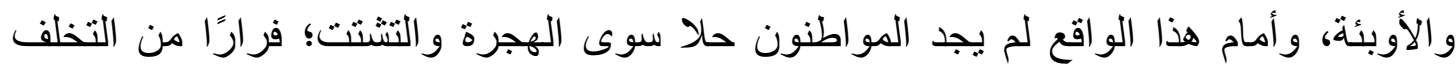

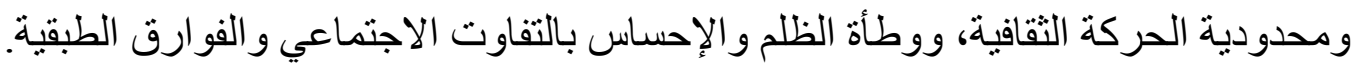

كانت تللك المرحلة قد طبعت الحياة بِيَّةِة الكفاح و المقاومة؛ لأن "هذا الثُعب قد استغرقته

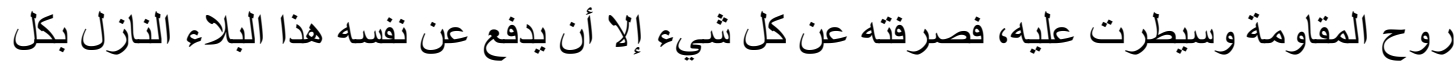

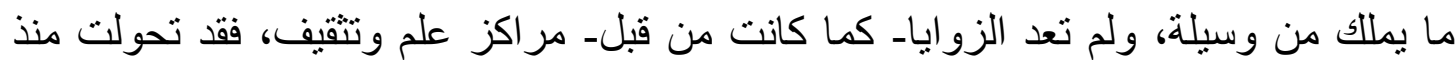

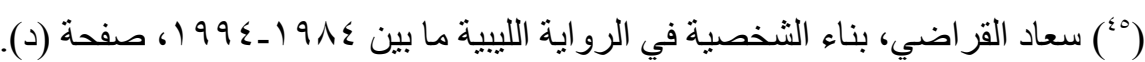
(7) أحمد عطية، في الأدب الليبي الحديث، دار الكتاب العربي للطباعة و النشر، طر البلس- ليبيا، د ط، د ت، 


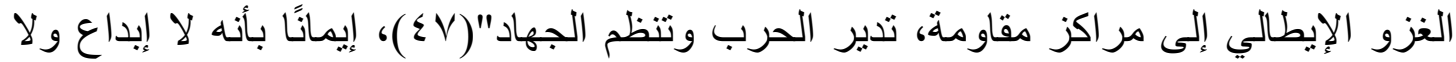

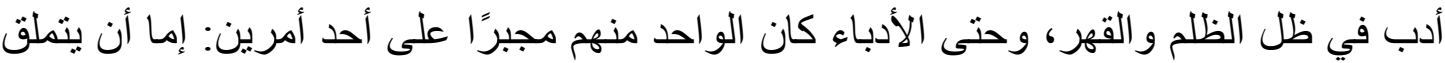

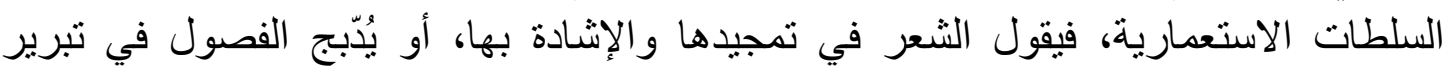
أخطائها، و إمَّا أن يسكت سكوت العاجز ، حتى لا يعرف عنه أنه شاعر أو أديب"(

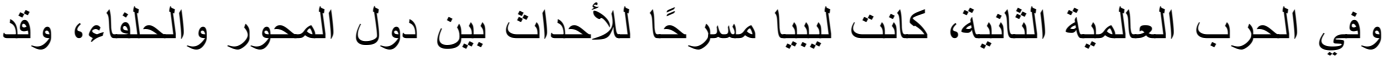

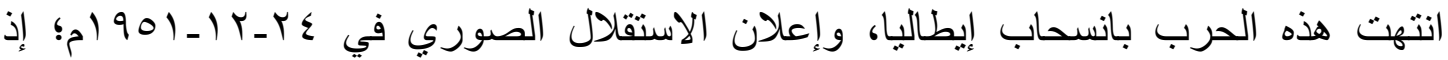
خرجت إيطاليا ودخلت بريطانيا، إلا أن ذلك شجع عددًا غير قليل من الليبيين الذين كانوا في

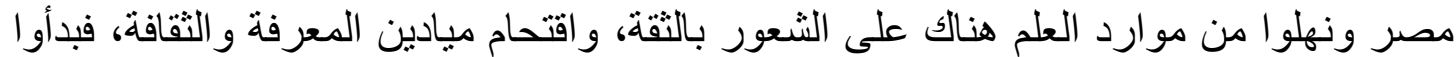

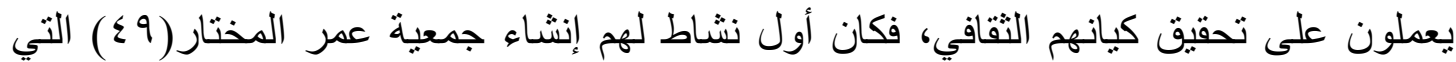

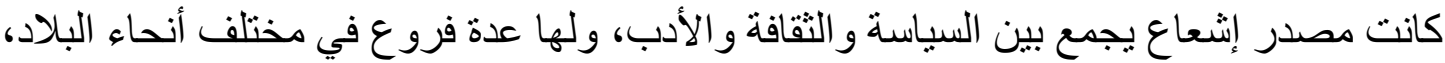

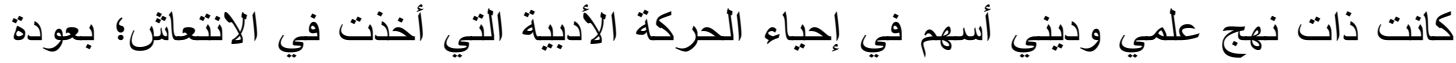

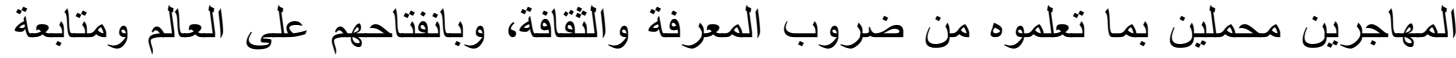
التيار ات الأدبية العالمية، مسهمين بذلك في مد جسور التو اصل التقافي مع الدول العربية وما فيها وبها من حركة أدبية.

ولم يمض وقت طويل حتى استقر الوضع نسبيًا، وهو ما سمح للرواية بالإعلان عن نفسها

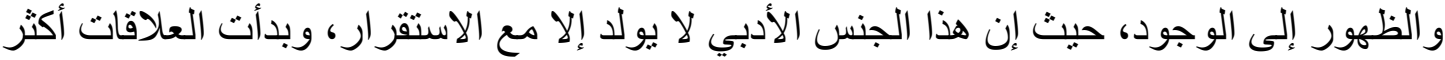
تشابكًا، فحين كانت علاقات الإنسان بسيطة لم تظهر الرواية؛ بل كانت الحكايات البدائية الشعبية

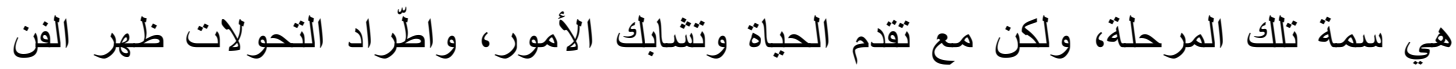

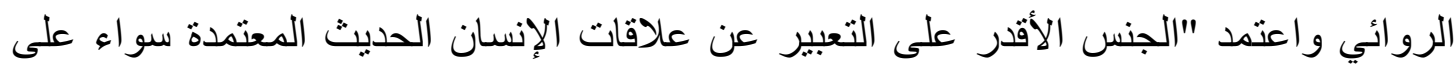

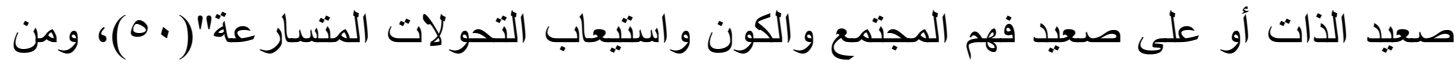
بين تللك التحو لات: الاستقر ار بالمدينة التي كانت مركزًا لحل النشاطات، خاصة الأدبية منها.

ارتبط ظهور الفن الروائي بالمدينة، وصار بعض المهتمين بالرواية يرون أنها "هي هيكلة أهنا

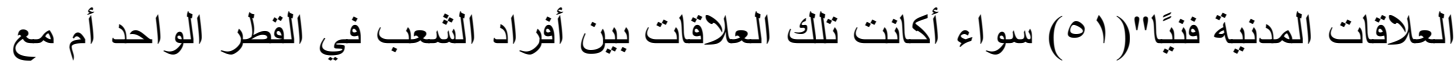
غيره، وفي طور من أطو ار النهضة كانت نشأة الرواية الليبية ثمرة من ثمرات احتكات الكاتك الليبيين ببعضهم في إطار حياتهم المدنية الجديدة، واحتكاكهم بغير هم من الثعوب بعد بـد جلاء الاحتلال،

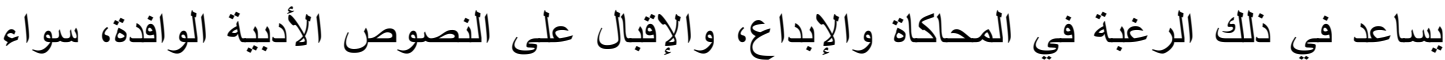
أكانت عربية التأليف أم كانت منرجمة في في فئ

(乏V)

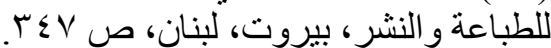

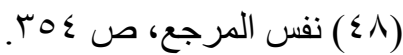

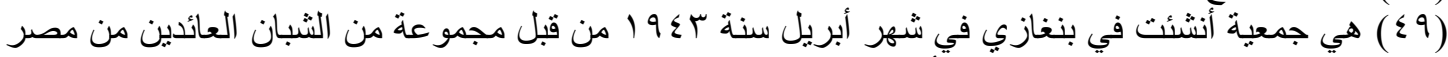

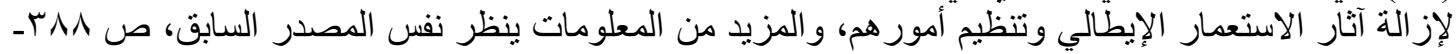

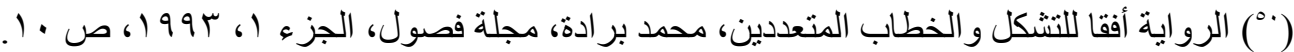

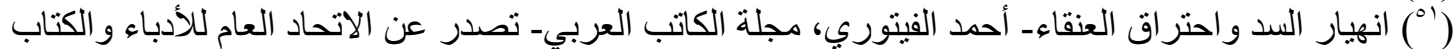

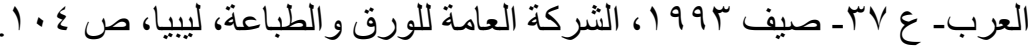


وقد كثر الإقبال على كتابتها وقر اءاتها بعد أن صارت واسعة الانتشار، وغمرت المكتبات الليبية والعربية، وكانت مصر أهم حلقة وصل بين ليبيا والعالم الخارجي، فعن طريقها دخلت

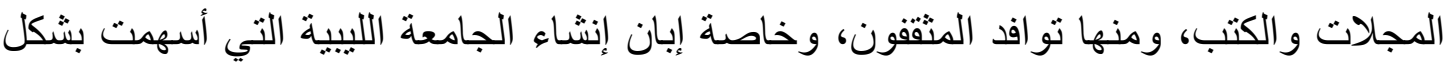
و اضح في نشر الثقافة بين الطلاب وفي المجتمع بصفة عامة منذ ظهور ها إلى الوجود في ذلك

كان لدور النشر أهمية في النهوض بالرواية اللبيية؛ حيث أسهمت في نشرها وتوزيعها،

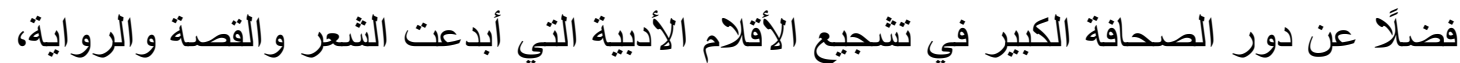

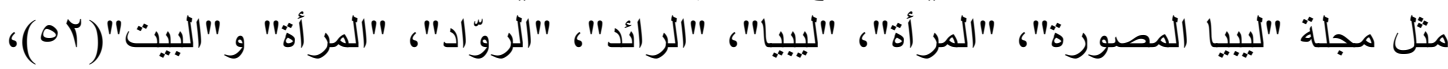
وغير ها من الصحف و المجلات التي نشر الأدباء إنتاجهم على أعمدتها.

عرف الليبيون القصة القصيرة أولً قبل الرواية، ولعل الرواية مرحلة تطورية تجاوزت كتابة القصة القصيرة، لذلك لم تكن للرواية استقلالية باعتبار ها فنًا قائمًا بذاته في بداية ظهور ها،

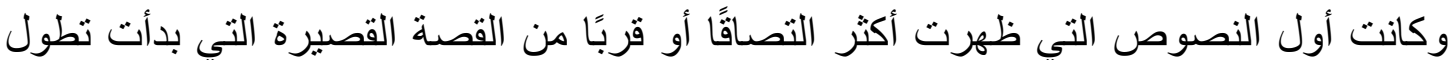

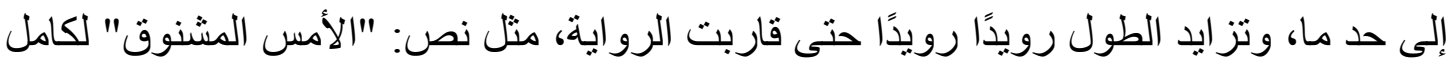

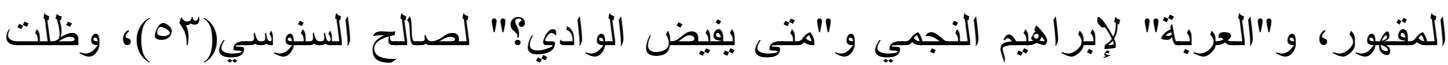

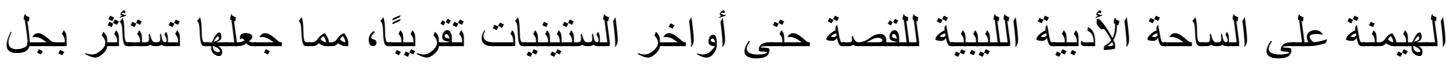
الدر اسات النقدية والأدبية التي اهتمت بها في مختلف مر احلها.

وما يؤكد انبثاق هذا الجنس الأدبي المستحدث في الثقافة المغاربية المعاصرة من الفن

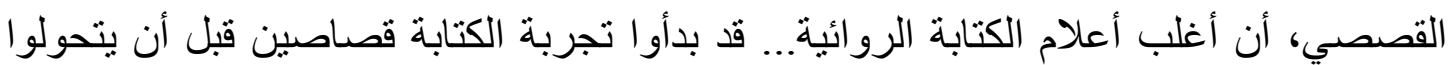

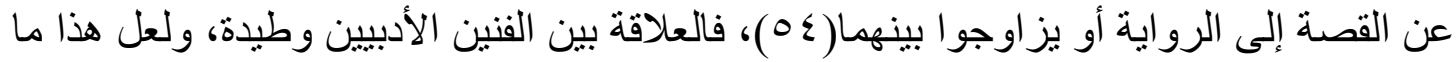
يبرر وجود بعض الأعمال القصصية القصيرة لروائيين ليبيين مثل: أحمد إبراهيم الفقيه، وخليفة ولينة حسين مصطفى، و إبر اهيم الكوني، ومرضية النعّاس.... الخ.

و إن كان بعض الأدباء قد جَمَع بين القصة والرواية، فإن بعضهم الآخر تحول إلى الرواية

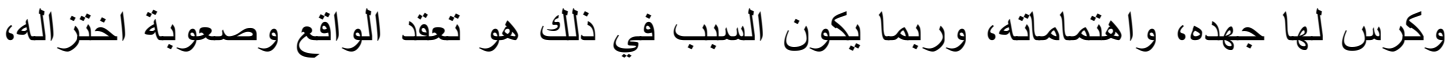

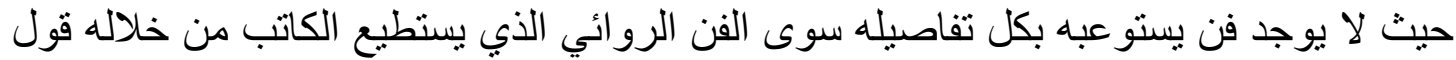

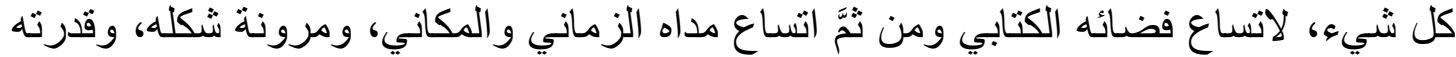

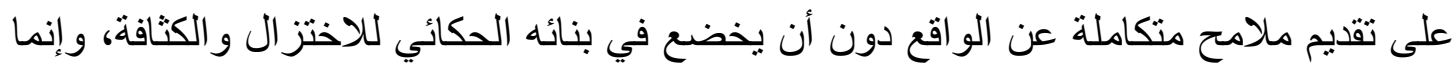
له قو اعده الخاصة التي تتيح له تمثيل المجتمع بشكل أكثر و اقعية.

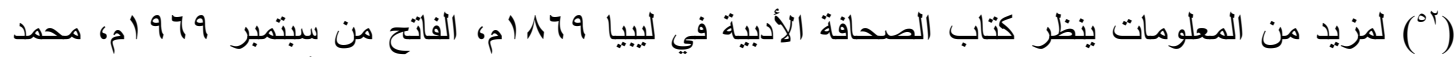

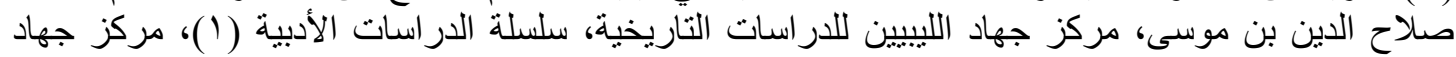

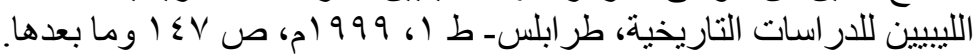

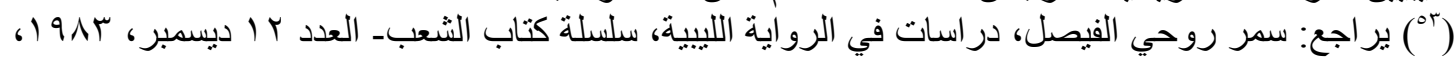

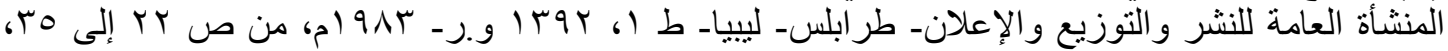

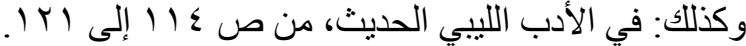

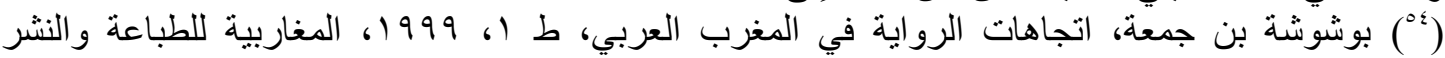


ويكاد دارسو الحركة الأدبية في ليبيا يجمعون على أن أول نص روائي ليبي هو "اعتر افات

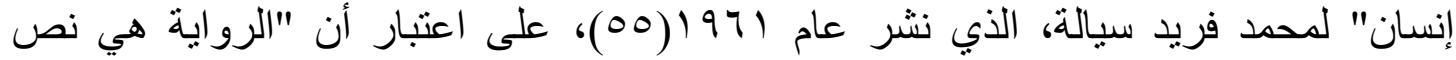

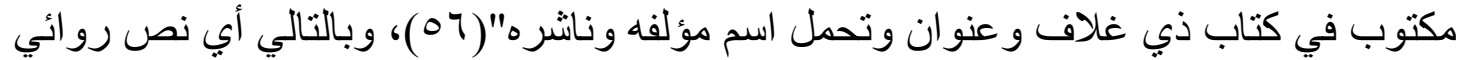
غير مطبوع في كتاب مستقل لا يُعد رواية.

إلا أن سليمان كثلاف يرى أن أول رواية لييية هي: "الحياة صراع" التي نُشرت على

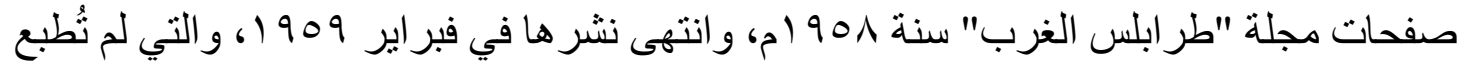

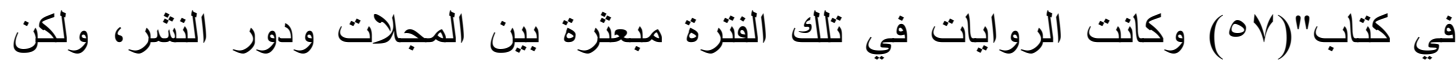
الدر اسات حولها أكثر بعثرة و غير منسقة مما جعل جمعها أمرًا مستعصيًا.

أما الصيد أبو ديب فيذهب إلى أن أول رواية ليبية صدرت في ديار الهجرة هي (مبروكة)

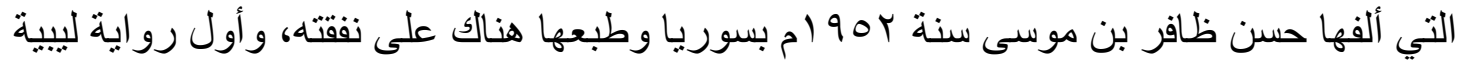

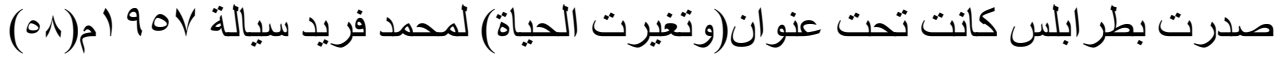

كان ميدان الكتابة الروائية ونقدها حديثي العهد نسبيًا- في فترة الستينياتـ وقد كانت المر اجع

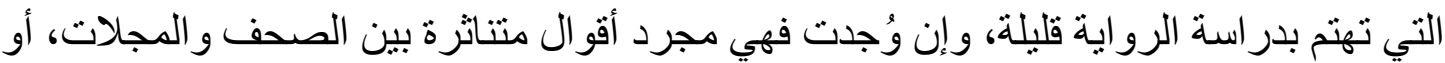
إثنار ات مختصرة على صفحات بعض الكتب و الرسائل العلمية، ولا تقف طويلًا عند روائل بذاتها؛ بل يكون الكلام عامًا.

وإن صادف ووُجدت در اسة حول رواية بعينها؛ فإنها غالبًا ما تكون قد صيغت بأسلوب هو

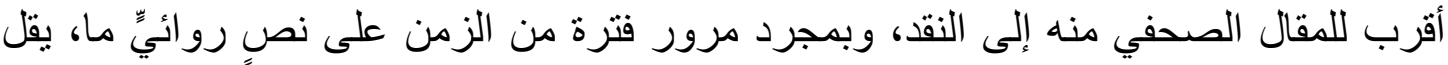
الاهتمام به حيث إن أغلب ما كُتب عن الروائب اته كان إبان ظهور ها.

وقد كانت جل الدراسات المنشورة في المطبو عات الليبية، تقف عند القصص، و لا تشير إلى في الرواية إلا باختصار، مثلما هو الحال في الدوريتين المعنيتين بشؤون الثقافة والأدب في ليبيا:

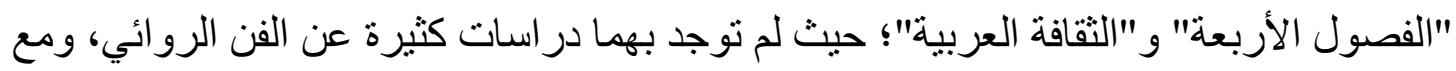

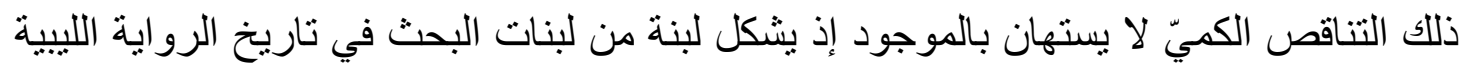

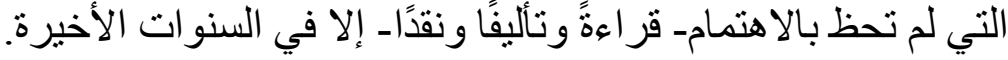

ولم يوجد نظام توثيقي خاص بتاريخ الرواية باعتبار ها جنسًا أدبيًا في ليبيا، ولعل هذا ما فيا

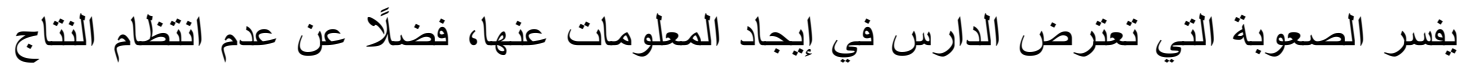

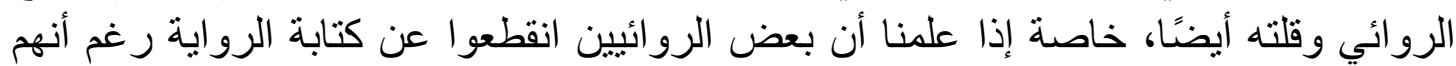
جربوا ذللك، مثل: رجب أبو دبوس، وكامل المقهور، ومرضية النعّاس وغيرهم، هُون ليس هذا فقط؛

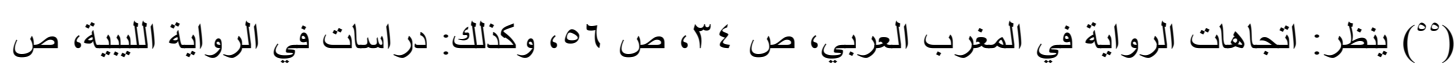

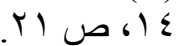

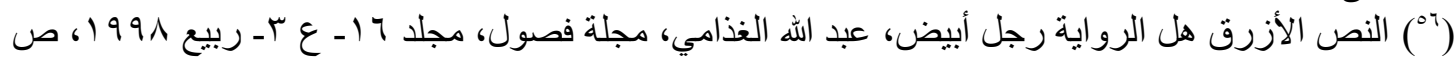

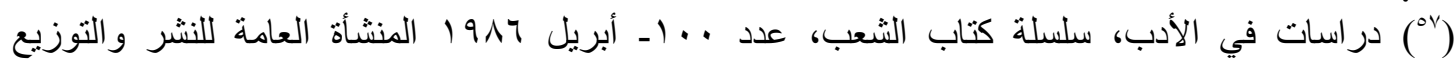

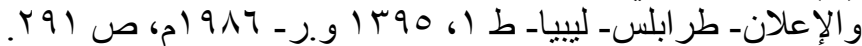

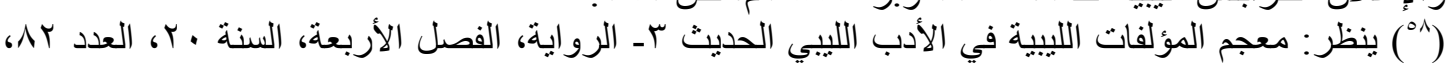




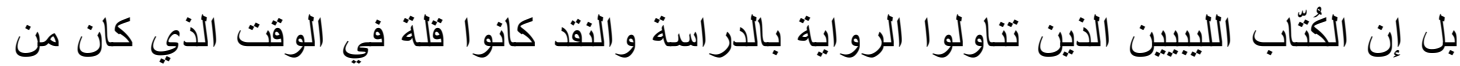

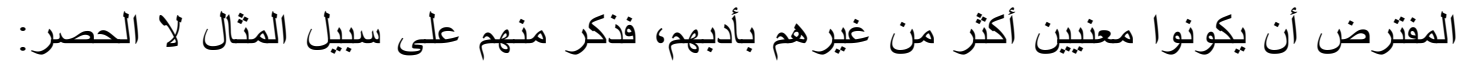

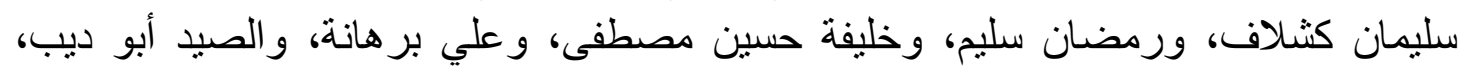
و أسماء الطر ابلسي، وفئل وفاطمة الحاجي..... الخ.

هؤ لاء في ليبيا، و على المستوى العربي تم تناول الرواية الليبية من قبل عدد قليل من الكتاب

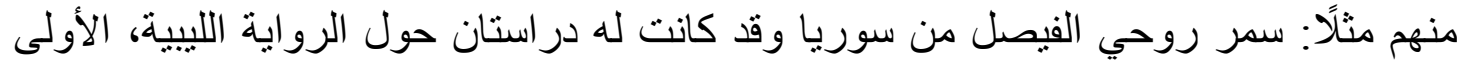

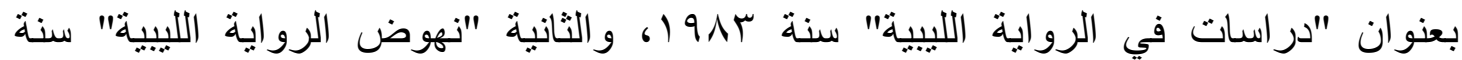

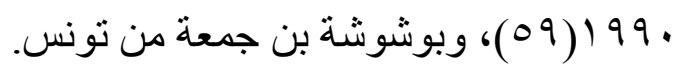

و هناك بعض ممن أرخو اللرواية العربية تجاهلوا الرواية الليبية مثلما هو الحال عند سيد فيد التها

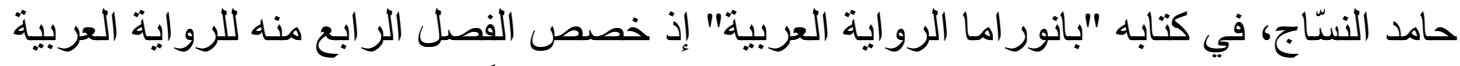

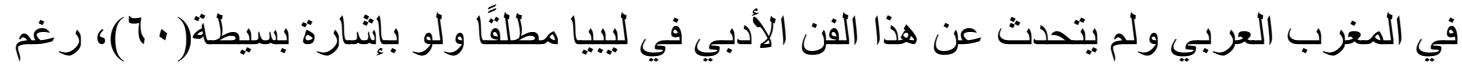

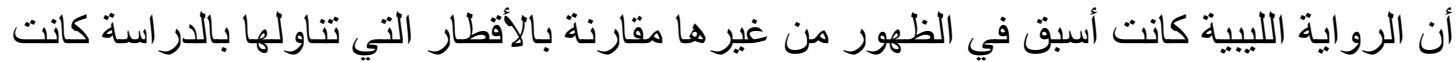

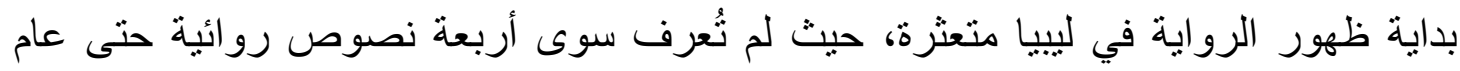

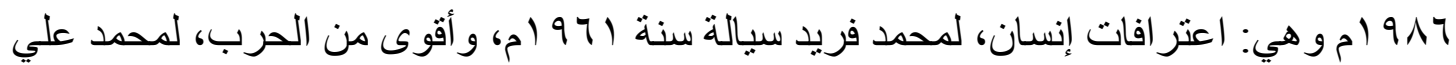

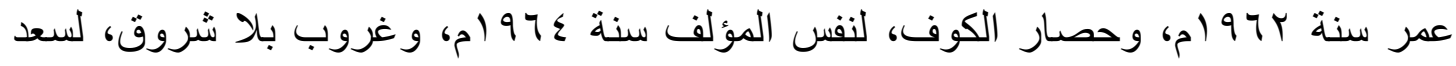

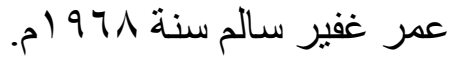

وفي السبعينيات تدفق ينبوع الرواية الليبية و أخذ عددها ينز ايد على مدى السنوات التي تليها،

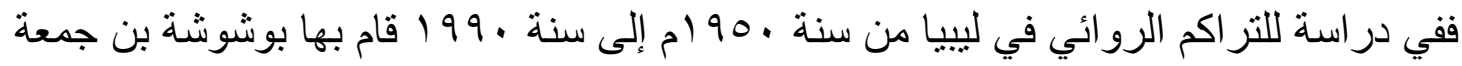

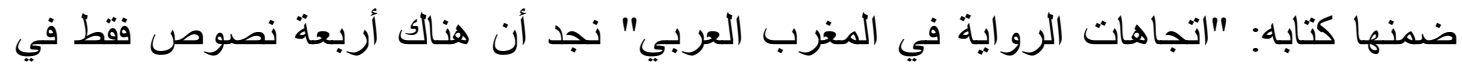

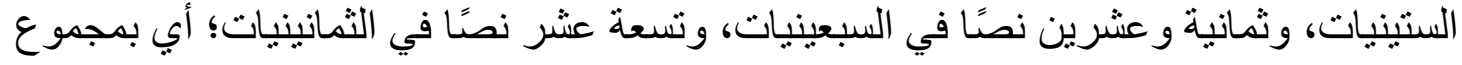

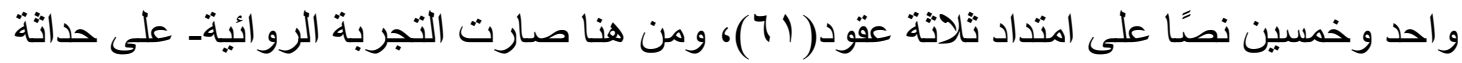

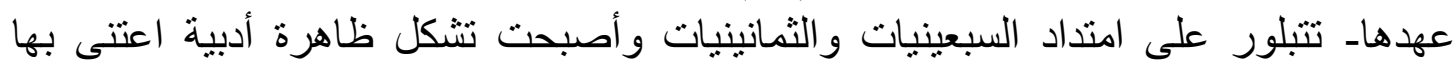
الباحثون و الكتاب بعد أن كانت إبان الستينيات مجرد محاولات فردية يغلب علئ عليها اللون الذاتي،

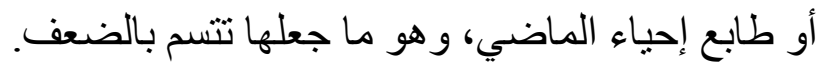

ويمكن اعتبار السنوات "ما بين عهو (م و ـ99 ام فترة ازدهار الفن الروائي في ليبيا

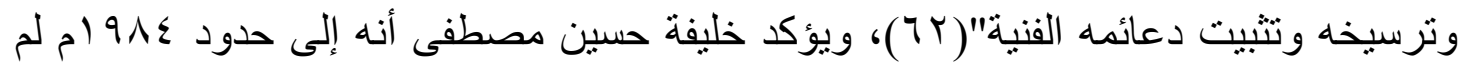

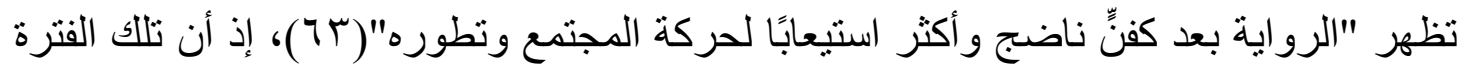

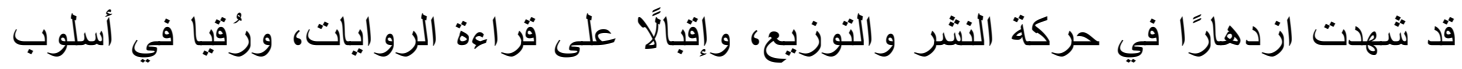

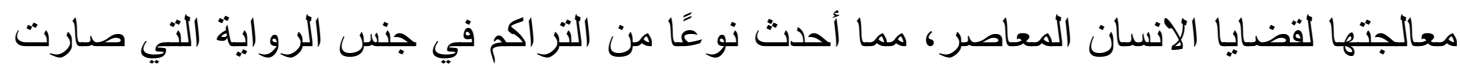

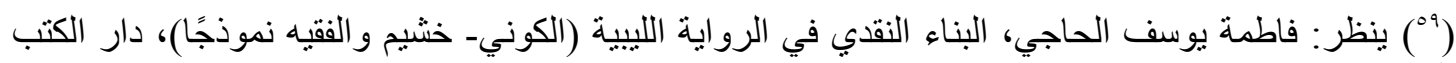

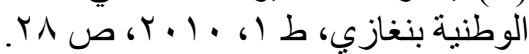

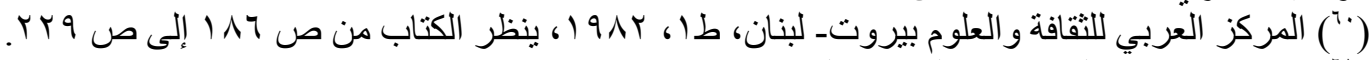

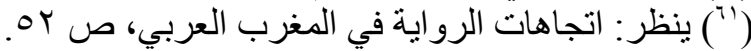

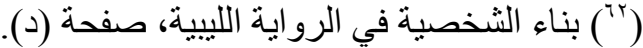

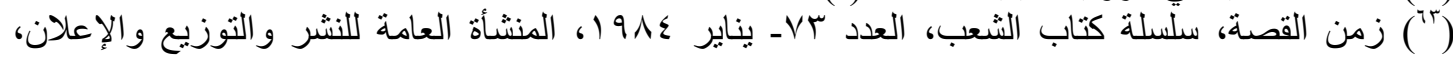

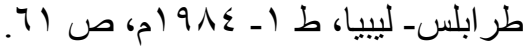


فن العصر ، يعالج بو اسطتها الأدباء شتى الموضوعات، وقد ساعدهم في ذلك "وفرة مطالعاتهم

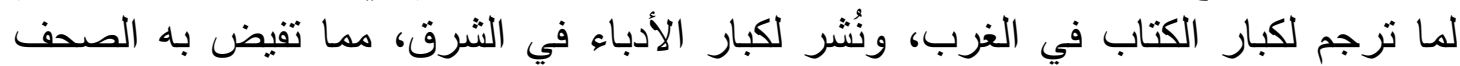

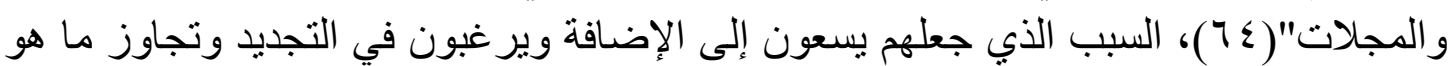

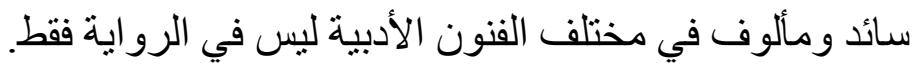
ورغم وجود كَّّ غير قليل من النصوص الروائية الليبية المطبوعة في كتب مستقلة؛ فإن هنالك

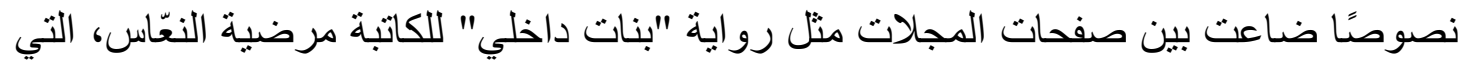

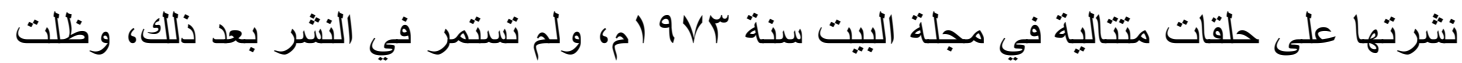

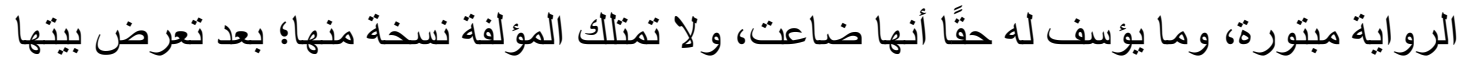

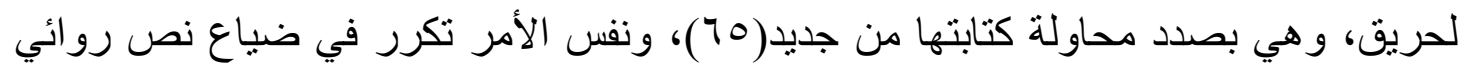

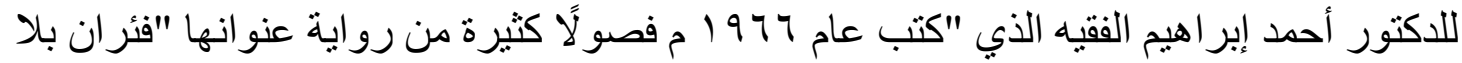

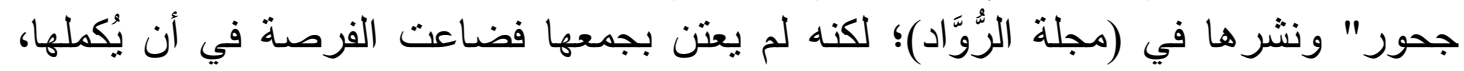

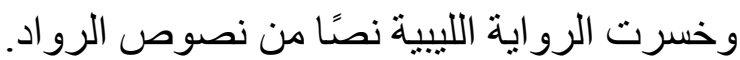

كما خسرت قبل ذلك نص رواية "الحياة صر اع" لمحمد فريد سيالة، الذي نُشر في مجلة "طر ابلس الغرب" عام 901 1، 909 1، و هو النص الذي عدّه النقاد البداية الأولى لفن الرواية

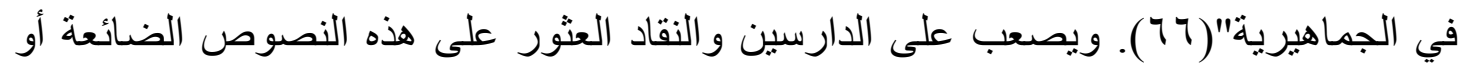
المبتورة من الدوريات الليبية، وفي حياة أصحابها الأصليين، فما باللك بعد وفاتهم.

ومن بين النقاد الذين أرخوا للرواية في الأدب الليبي، وأوجدوا ثنتًا لهم: أسماء

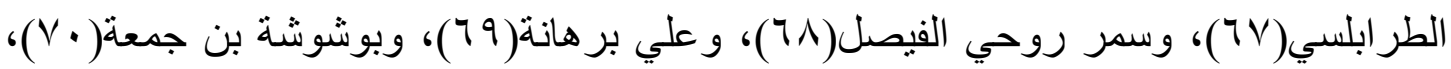

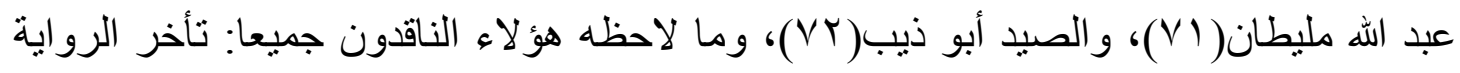
في الظهور، نظرًا لأنها تقتضي تقاليد سردية معينة لم تكن الظروف الأدبية في ليبيا مناسبة لها.

(צ') بشير الهاثمي، خلفيات التكوين القصصي في ليبيا، طا، ـ19 ام المنشأة العامة للنشر و التوزيع والاعلان،

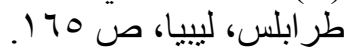

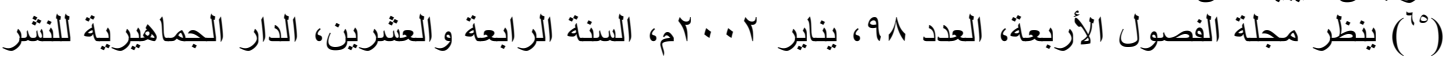

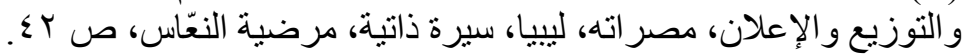

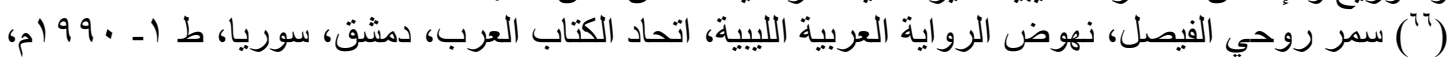
ص ro ro

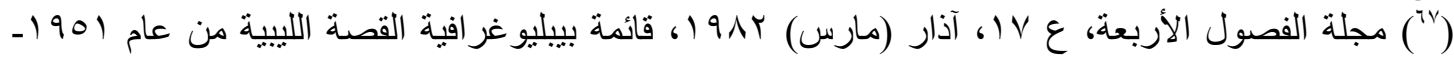

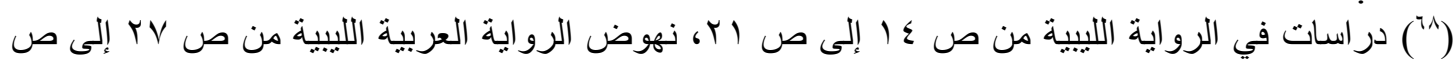

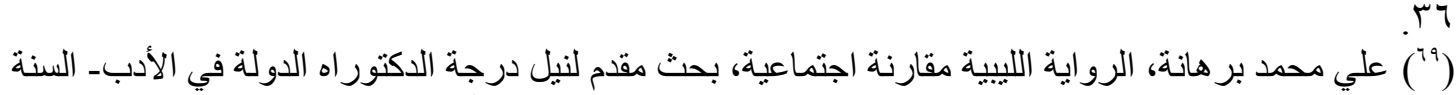

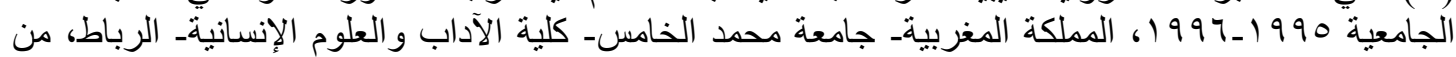

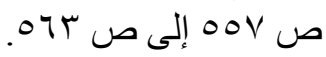

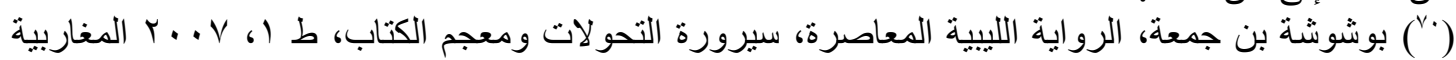

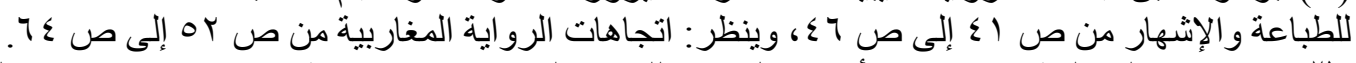

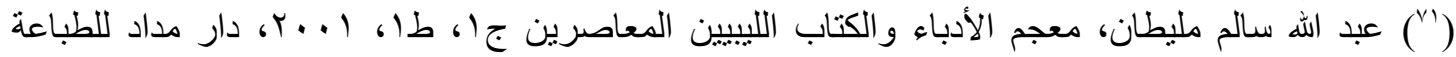
و النشر و النوزيع والنتاج الفني.

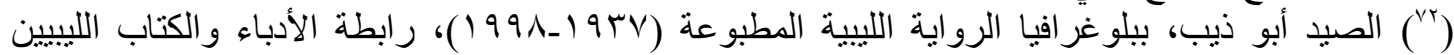

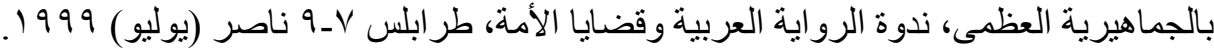


فما كان موجودًا آنذاك لا يتمانشى مع طبيعة الفن الرو ائي الذي اهتم في بداياته بمختلف قضايا

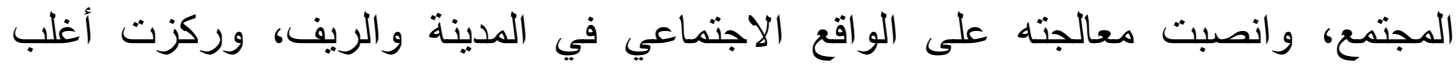

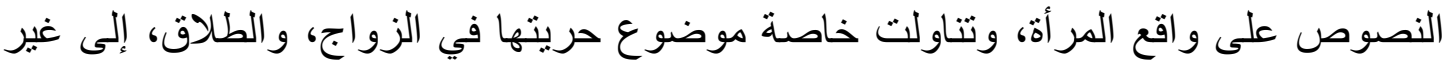

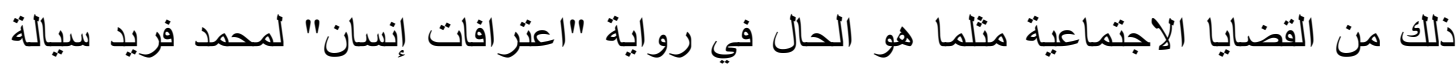
و "المظروف الأزرق" لمرضية النعاعية النعاس.

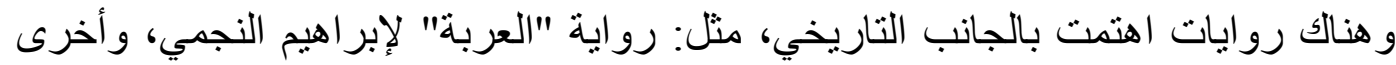

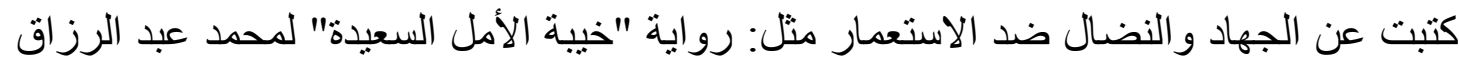

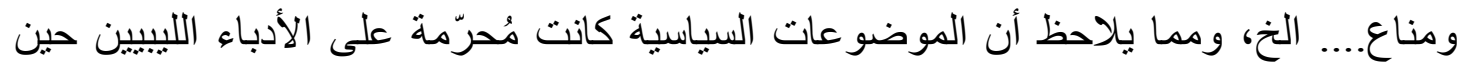

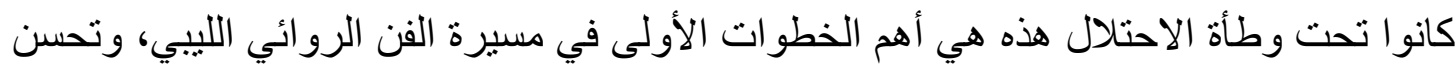

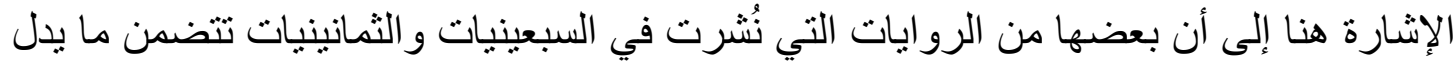

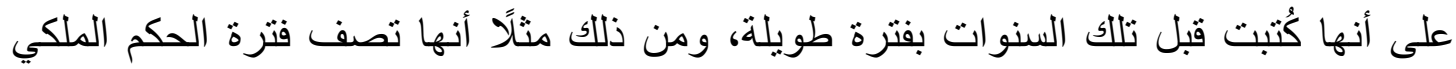
و الاستعماري.

\section{نشأة الرواية النسائية اللبيية}

لم تكن الرواية النسائية بمعزل عن الرواية الليبية عامة، سواء من حيث النشأة أم الظروف الظف التان

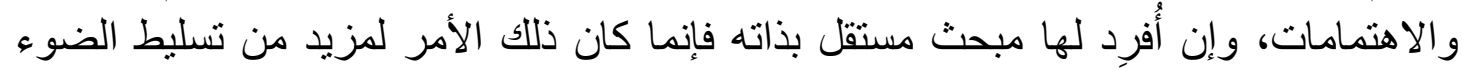
عليها وتحديد معالمها لأنها مدار الدار اسة هنا.

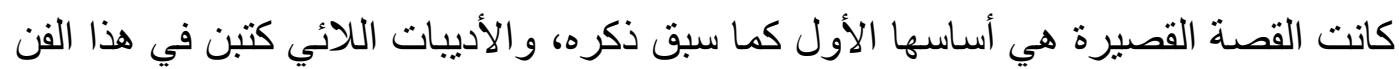

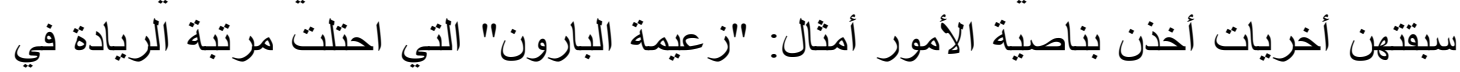

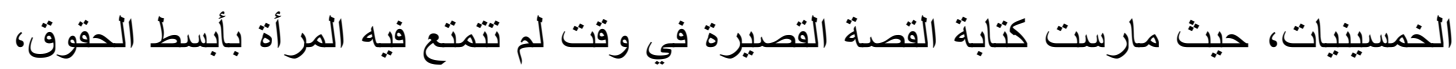

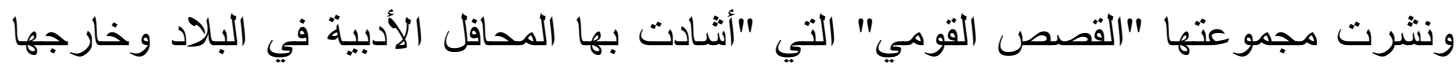

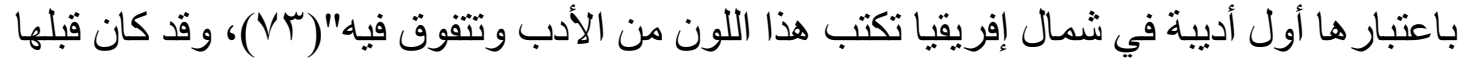

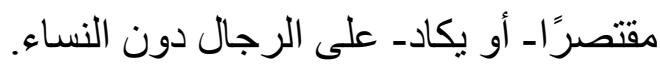

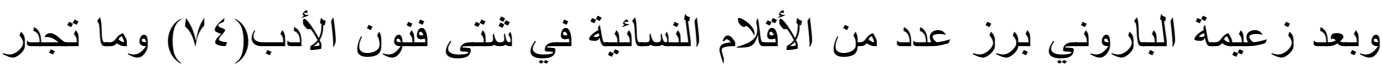

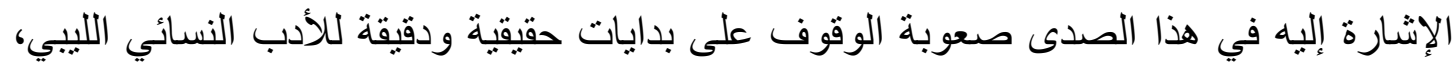

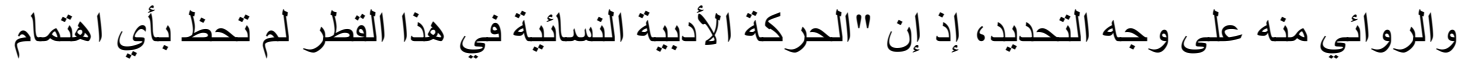

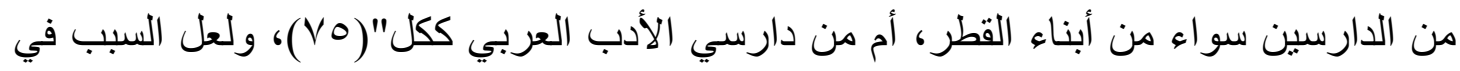

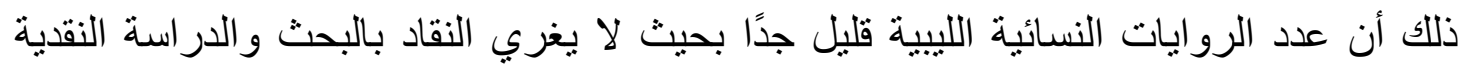

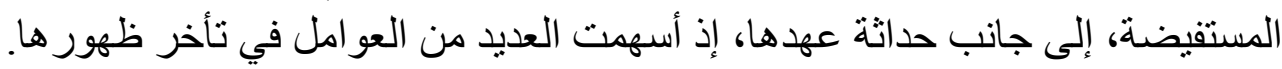

ومن بين تللك العو امل: الو اقع الاجتماعي الذي يرى الرجل صاحب سيادة مطلقة، و لا يسمح

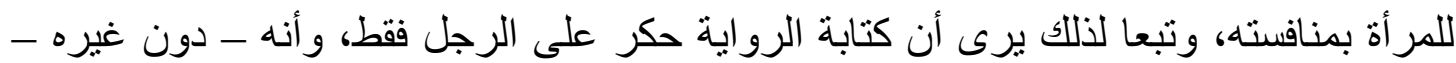




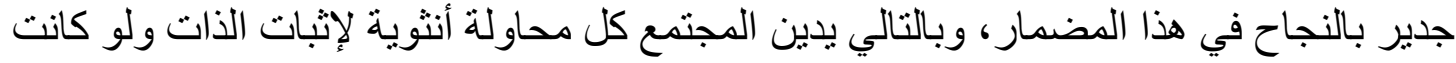

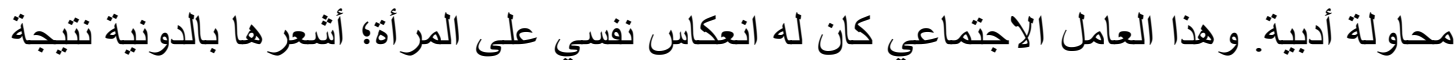
لاستخدام الرجل مقاييس قديمة في تقييم سلوكها.

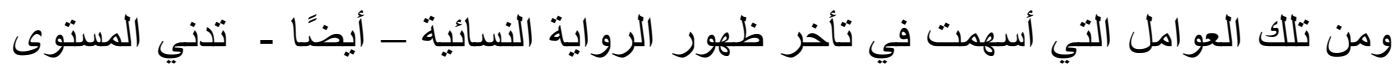

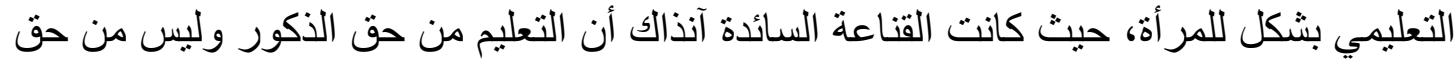
الإناث، وربما هذا هو ما جعل النصوص الأولى لا ترى النور إلا بعد فترة طويلة من كتابتها.

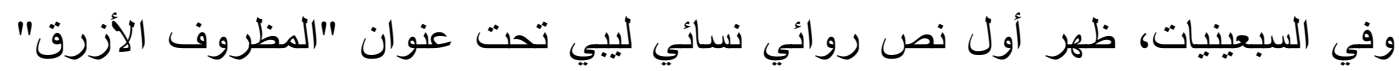

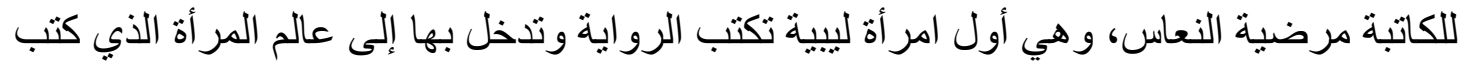

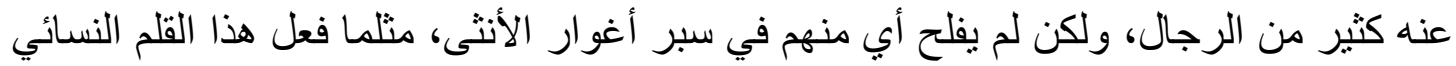
و وغيره ممن تلاه في المجال نفسها.

مرضية النعاس كتبت روايتها سالفة الذكر، ونشرتها على حلقات في مجلّة المرأة لسنة

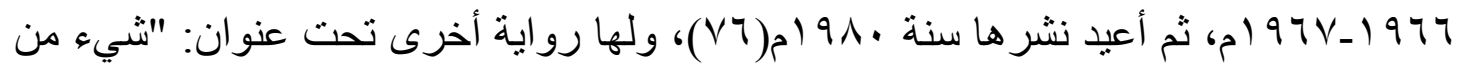

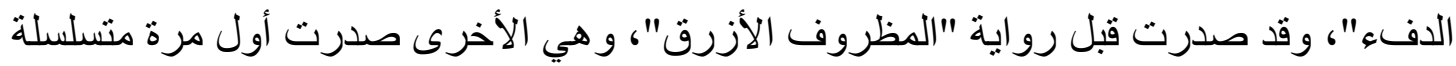

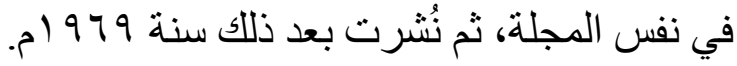

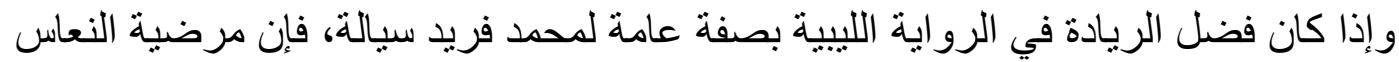

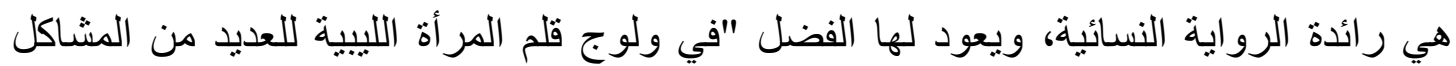

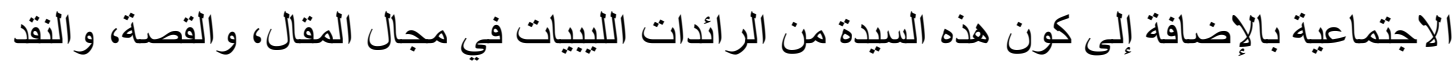

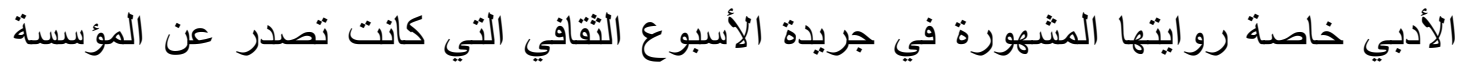

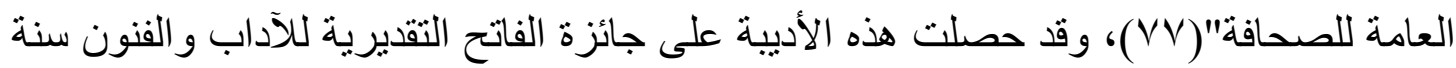

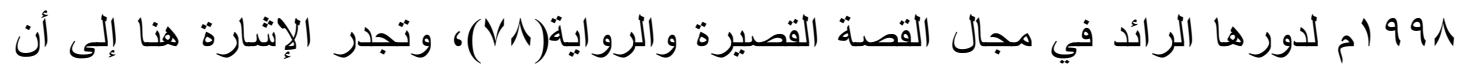
المصادر الليبية ذكرت لهذه الأديبة أربعة نصوص الفية روائية هي علي الترتيب التاريخي:

$$
\begin{aligned}
& \text { شيءٌ من الدف، نُشرت سنة } 979 \text { ام. }
\end{aligned}
$$

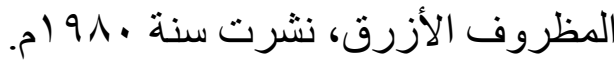

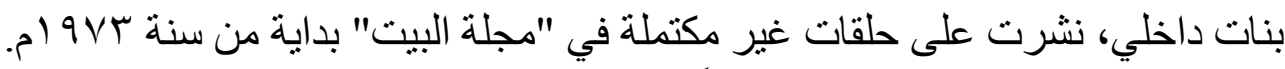

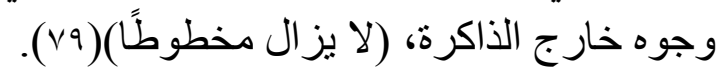

ثم تتابع ظهور النصوص الروائية، وإن كانت الفترة بين نص و آخر تتجاوز العقد من الزمن

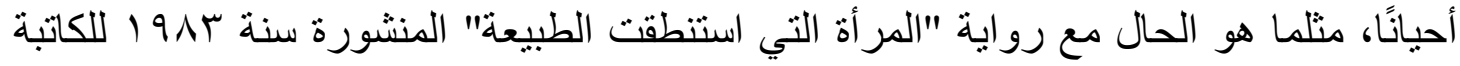

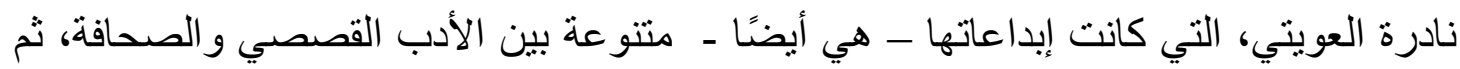

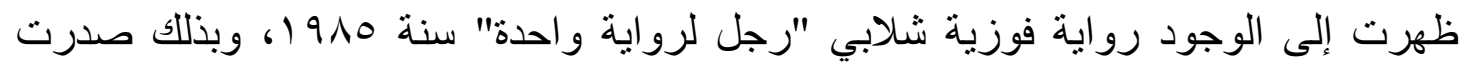
روايتا "هذه أنا" سنة الرجد رواية 1990 و "البصمات" 1991 الثريفة القيادي التي بدأت في نشر إبداعها

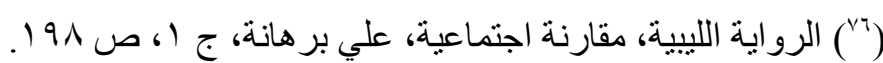

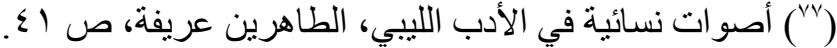

$$
\begin{aligned}
& \text { (N) }
\end{aligned}
$$

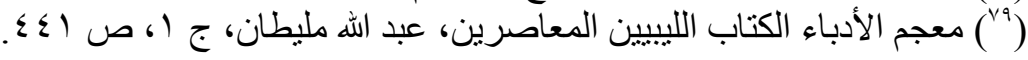




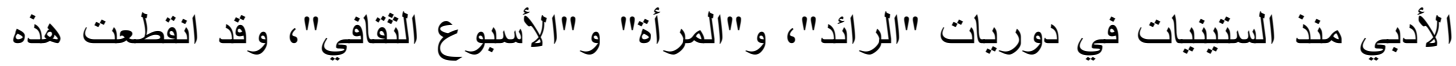

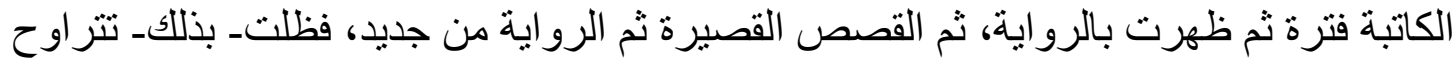

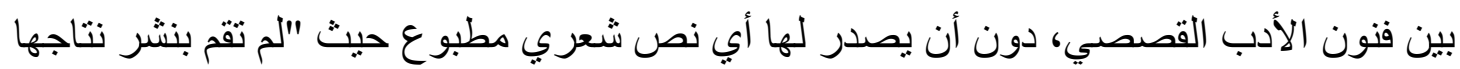

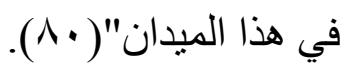

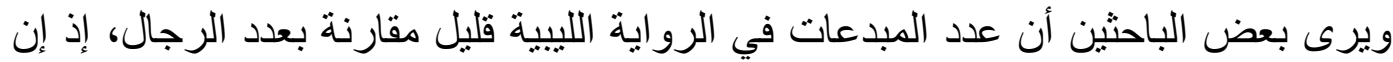

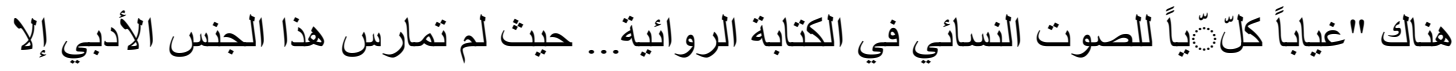

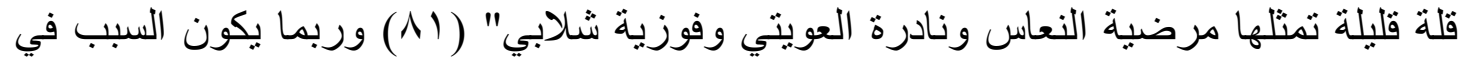

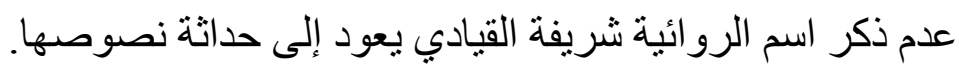

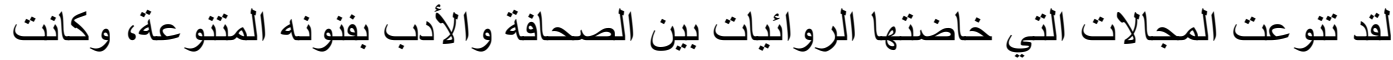

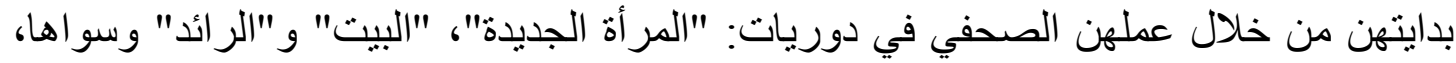

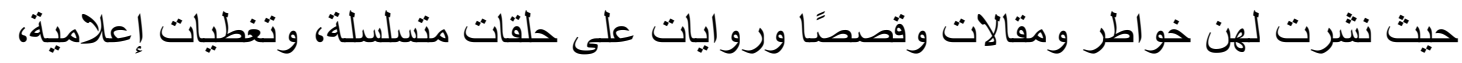

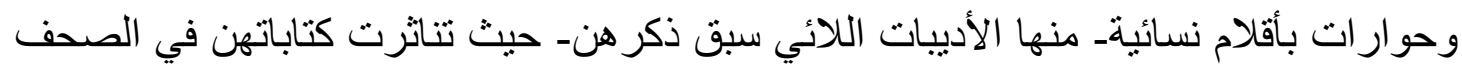

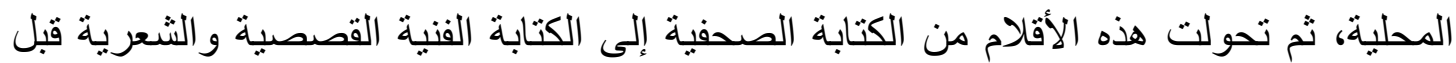

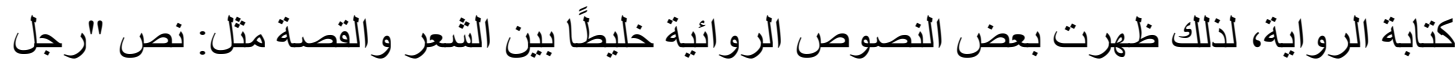

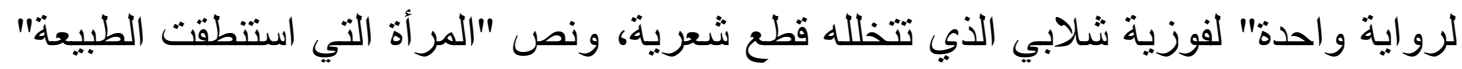

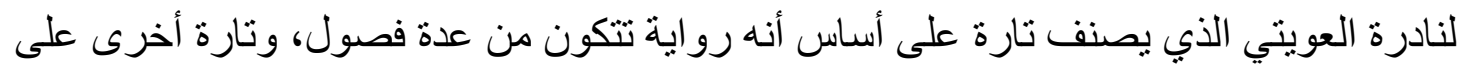

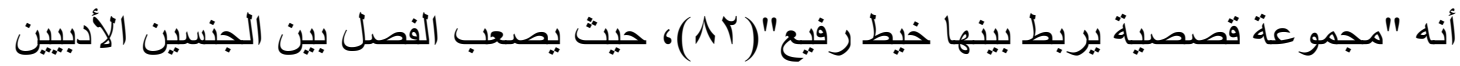

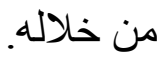

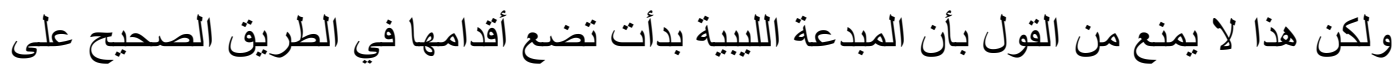

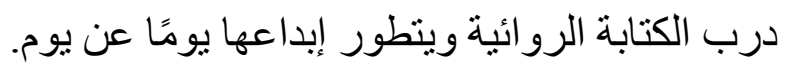

ورغم ما يقال حول المر أة- لا سيما الأديبة المبدعةـ من أنها تجد نفسها في الثعر و القصة

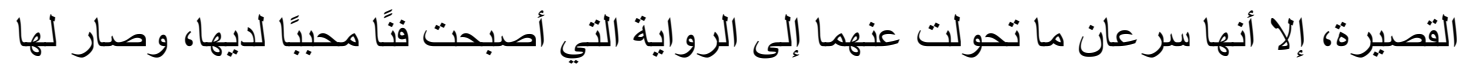

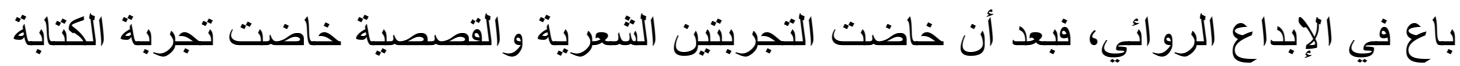

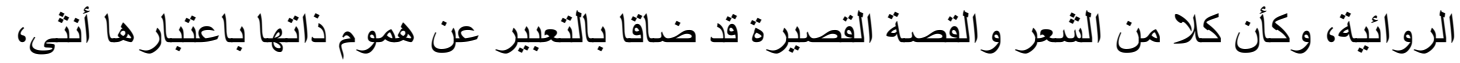

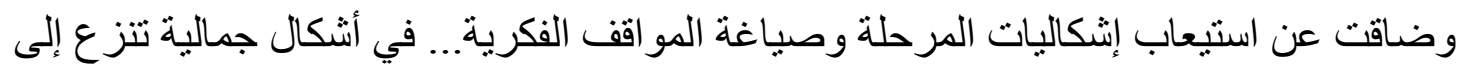

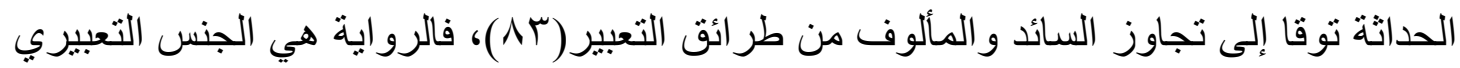

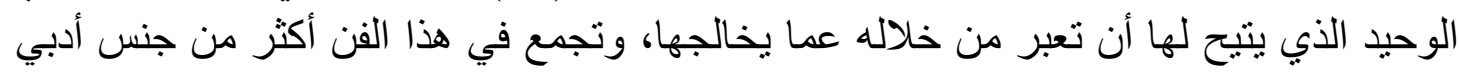

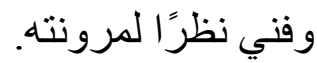

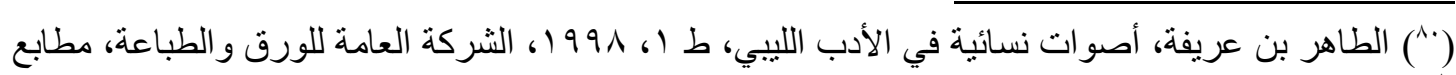

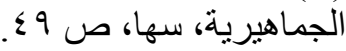

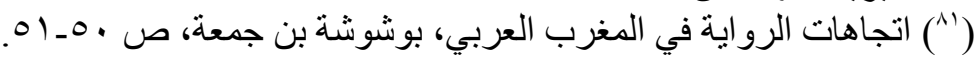

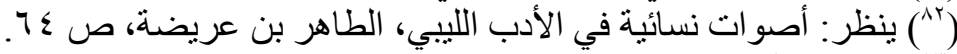

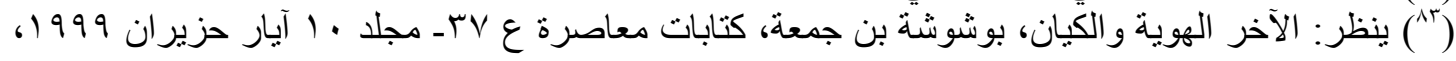




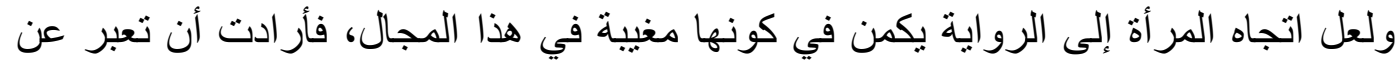

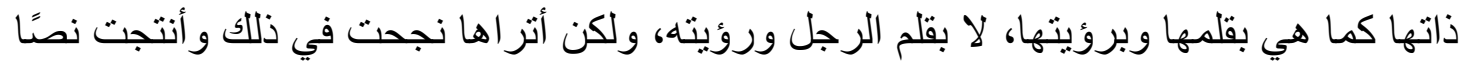
روائًاً تنطبق عليه الثروط الفنية لهذا الفن، أم إنها قدمت "نماذج هجينة يعسر على لئى الناقد تقييمها حيث يكون أمام شتات من النصوص. علهي و والكتابات التي يتداخل فيها أكثر من جنس أدبي ولون إبداعي" (^)

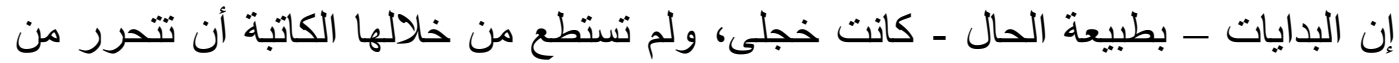
القيود الاجتماعية، وتمارس حريتها، وتطالب بما تريده، وكما يقول بشير الهاشمي ملخصا مرحلة البدايات الأولى للرواية النسائية: "لم أجد واحدة تصيح بأنها في حاجة إلى إلى كل مزايا

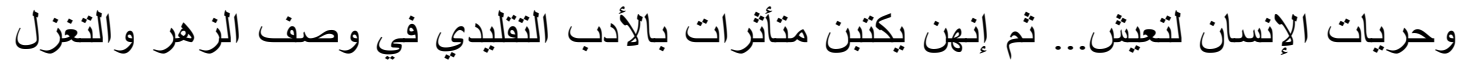

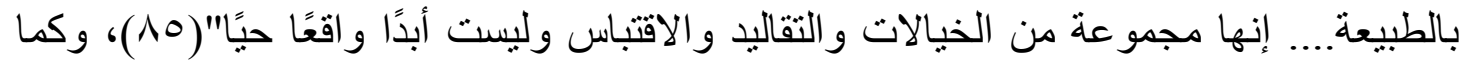
يتبين لما من هذه الثهادة أن المرحلة الأولى للفن الروائي عند الأديبة الليبية لم تكن تصويرًا

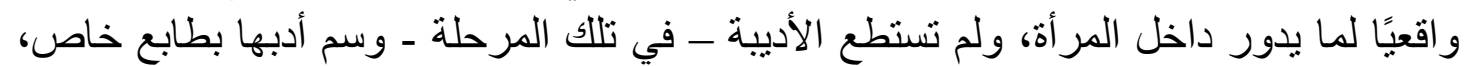

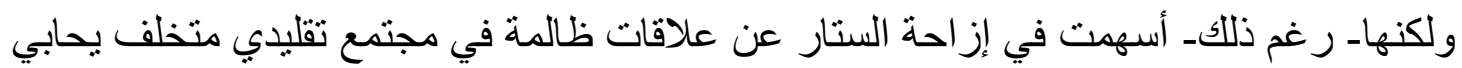

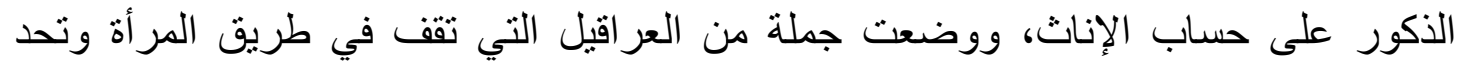
مسيرتها.

كتبت الروائيات عن هو اجس المر أة، وسافرن في أعماق وجدانها، وصورن ما يتملكها من

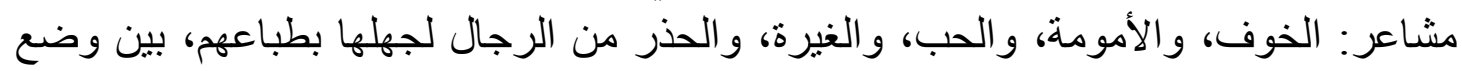

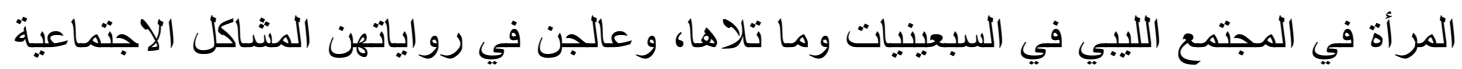

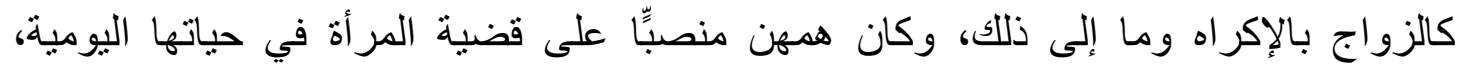

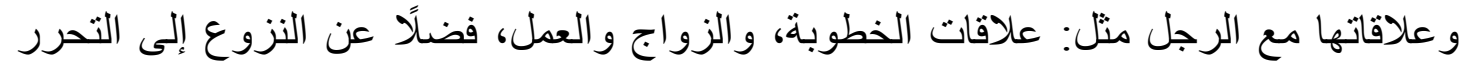

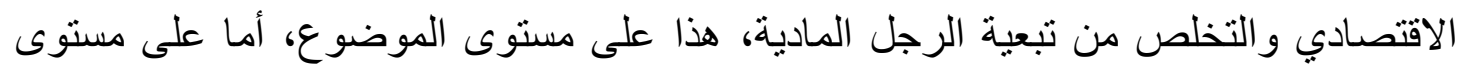

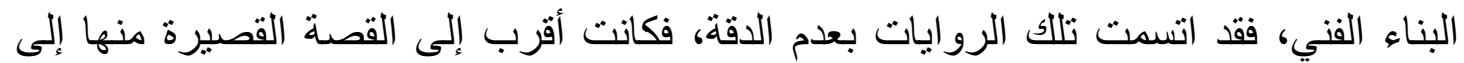
الرواية.

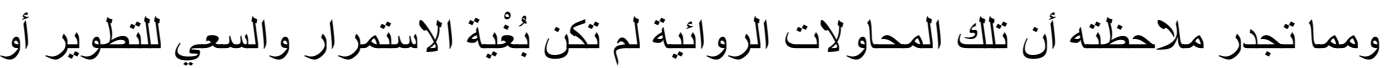
ترسيخ نمط أدبي معين؛ بل كان يغلب عليها طابع التجريب مما جعل النص الرو ائي النسائي يتسم

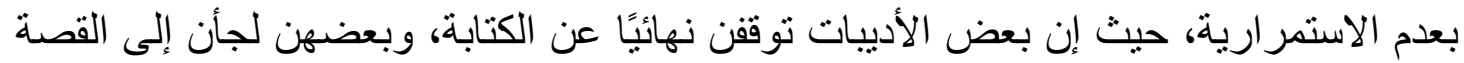

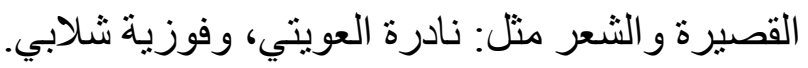

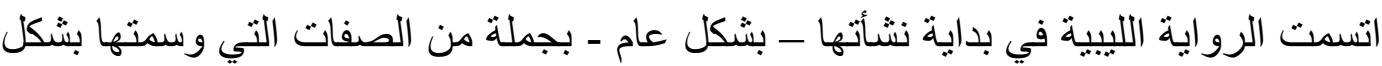

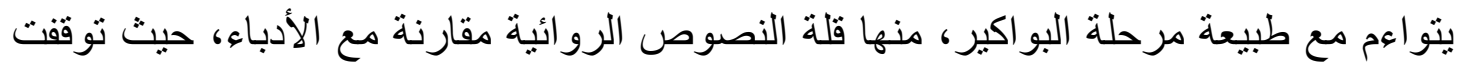
بعض الأقلام عن الكتابة الروائية بمجرد صدور نص أولية أو نصين مما سبب ظاهرة "غياب الانتظام

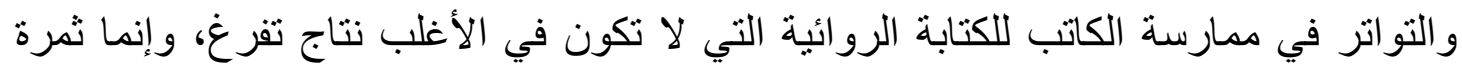

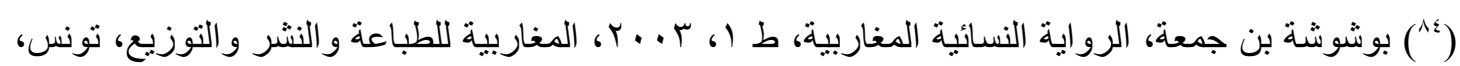




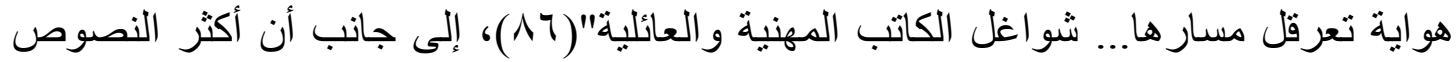

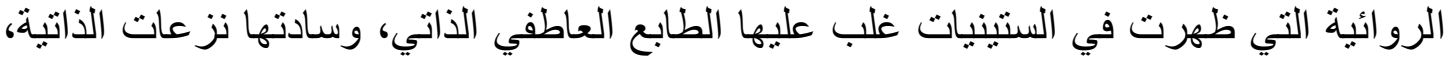

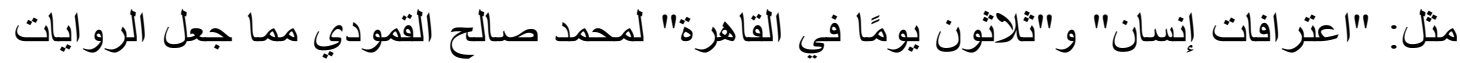

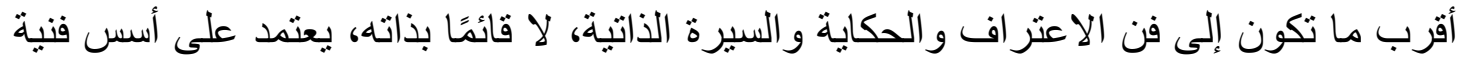
متكاملة خاصة، ولعل هذا مما يمكن التغاضي عند التهاية وال كونها في فترة النشأة.

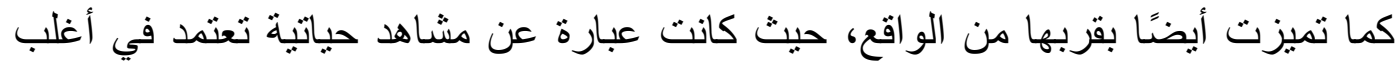

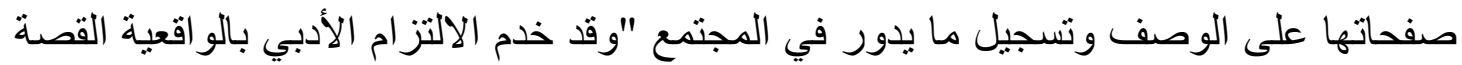

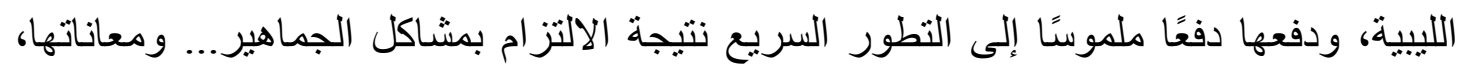

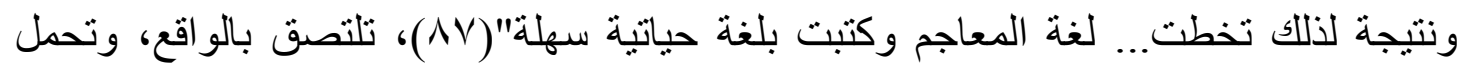

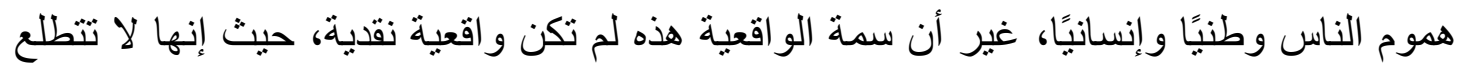
إلى الأفضل؛ بل اكتفت بالاحتجاج في أغلب الأحيان.

ومما عُرف عن الرواية الليبية في بداياتها الحضور الفوري للحس الوطني في نصوصها،

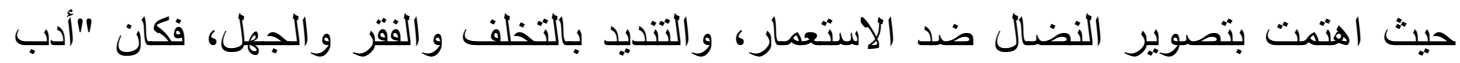

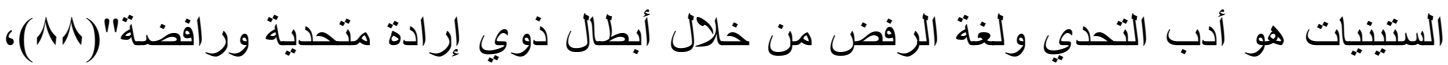

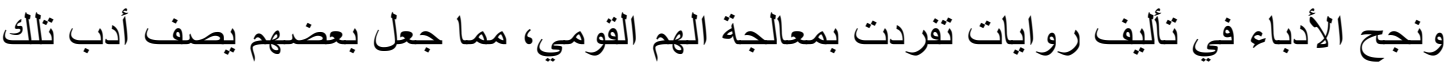

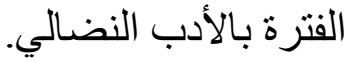

وسواء أكانت هذه الروايات اجتماعية أم قومية فإن مبدعيها لم يولوا اهتمائًا كبيرًا بينائها

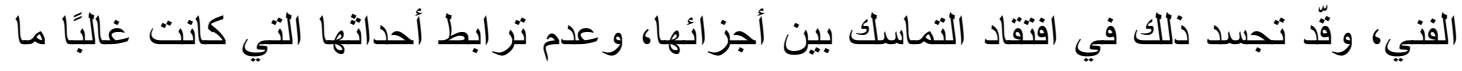

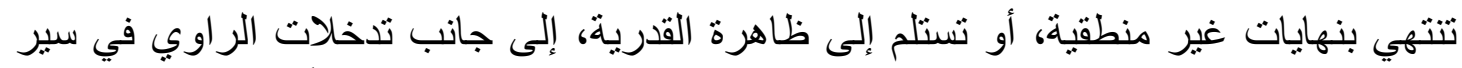

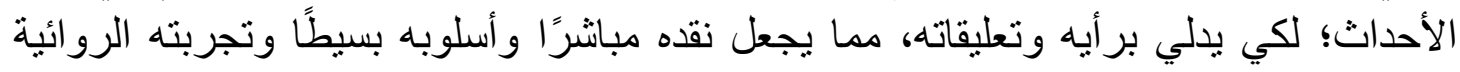

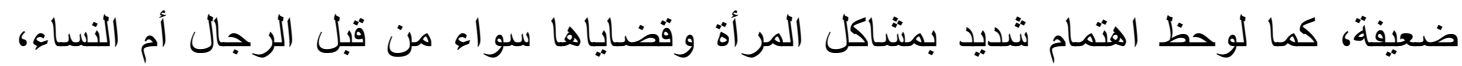

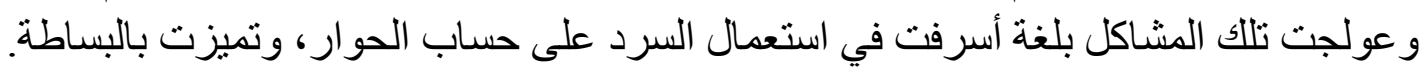

وعولجت القضايا المطروحة في تلك الروايات بأسلوب و عظي "حيث إن النزعة الخطابية

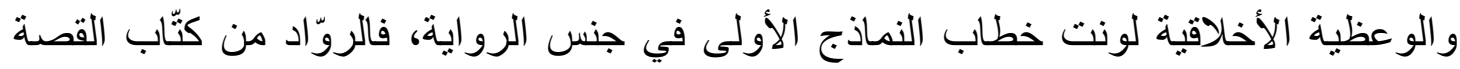

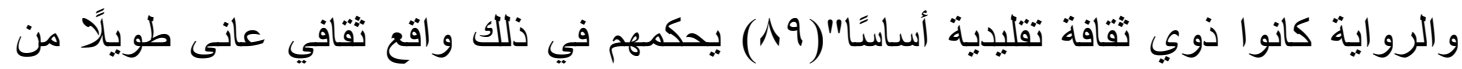
العزلة، وحُرِم من الاتصال بالمطبو عات العربية و العالمية، وأنماط الثقافات المتنو عة بأي شكل

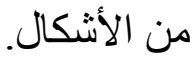

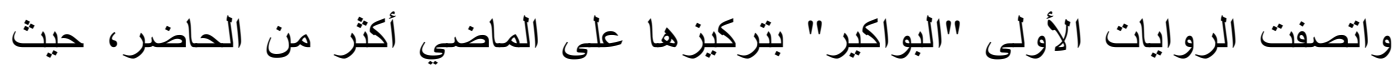

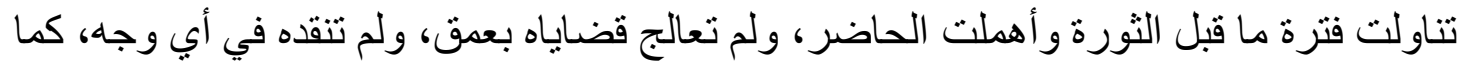

$$
\begin{aligned}
& \text { (17) اتجاهات الرو اية في المغرب العربي، بوشوشة بن جمعة، ص صـ } 10 .
\end{aligned}
$$

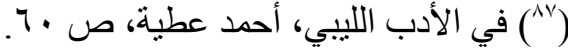

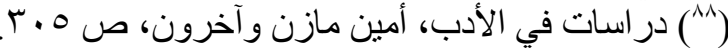

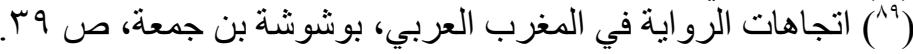




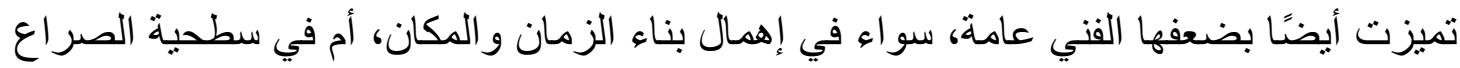
وضعف مصداقيته، أم في ضعف بنَ بناء الثخصية الروائية.

أضف إلى ما تقام عدم وجود وحدة للحدث وقوة حضور السرد على حساب الحوار،

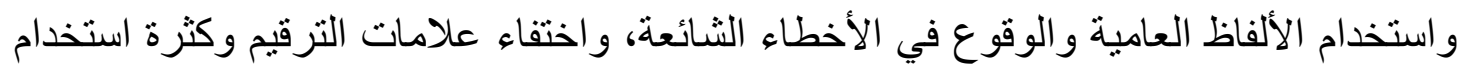

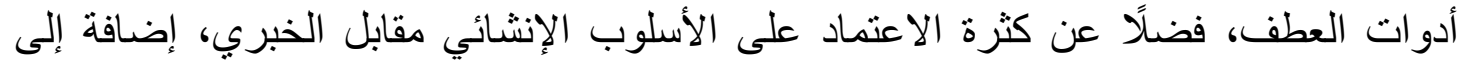
التعامل المباشر مع الثخصيات وتدخل المؤلف في ذللك.

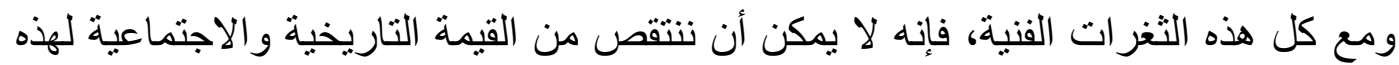

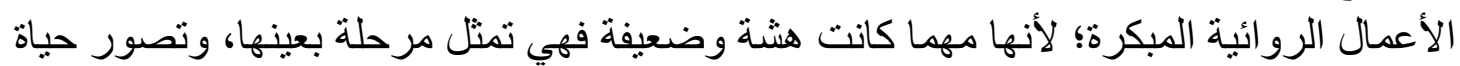

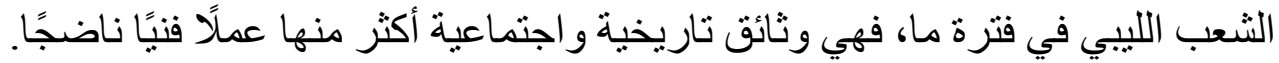




\section{الخاتمـــة}

وب وبعد، ففي ختام بحثي هذا المرسوم بـ: (السرد النسائي في الرواية الليبية) أرى من الأهمية

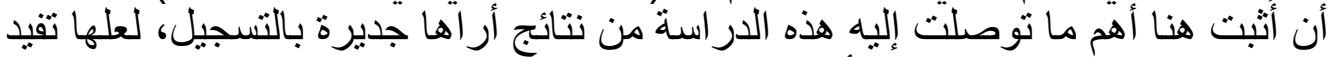

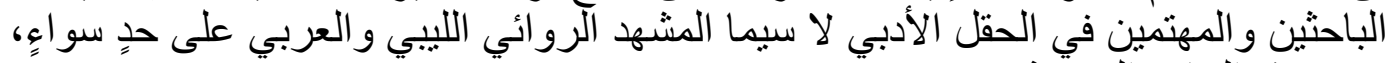
ومن هذه النتائج الرئيسة:

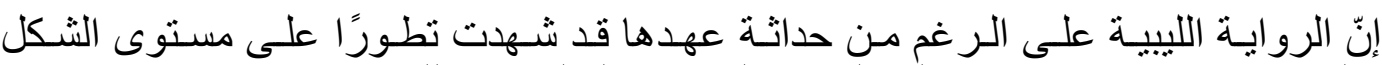

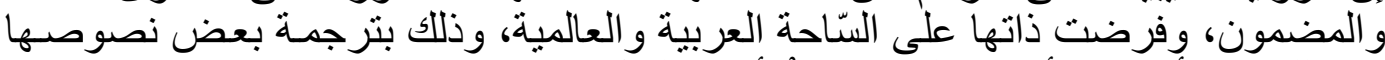

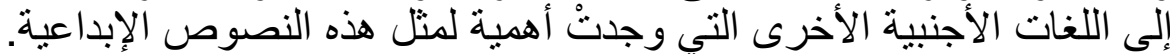

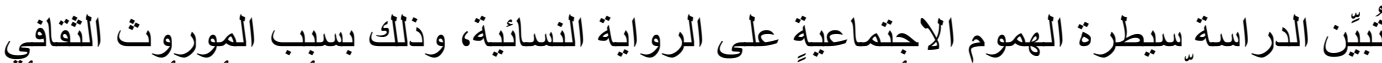

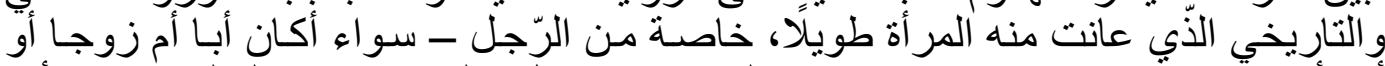

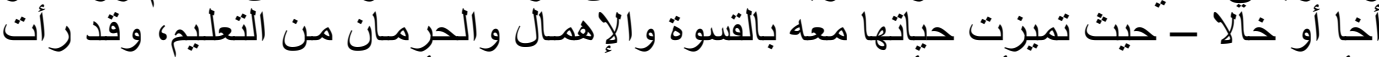

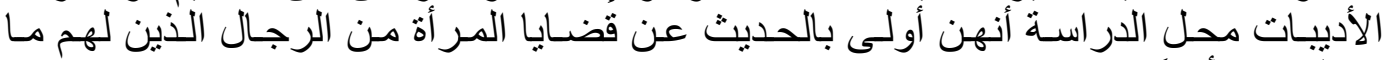
يشغلهم هم أيضًا.

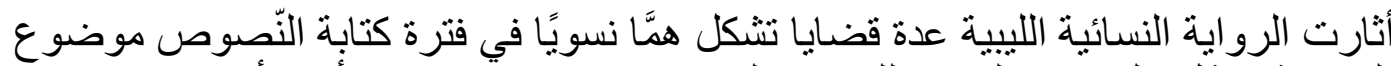

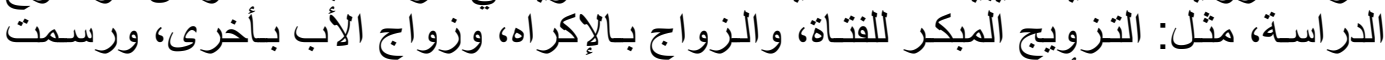

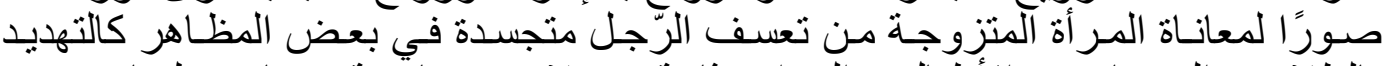

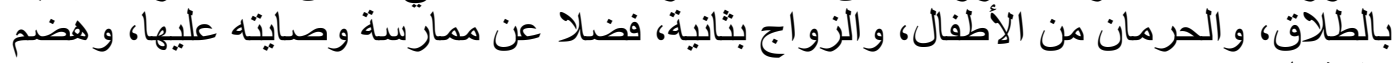
حقوقها.

يساعد الأدب النسائي في التعرف إلى نوعيـة إحسـاس المر أة في تعاملها مـع مـا يحبط بهـا

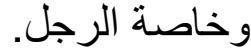

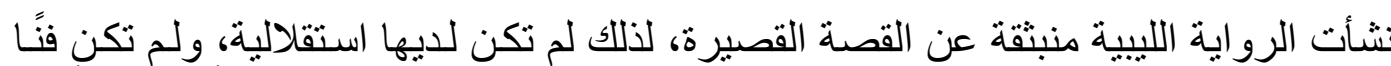

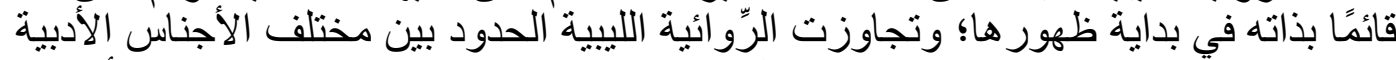

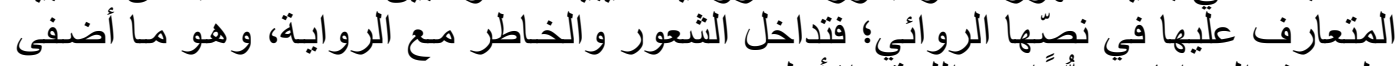

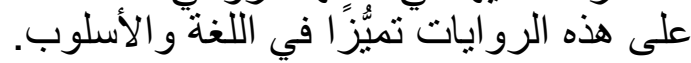

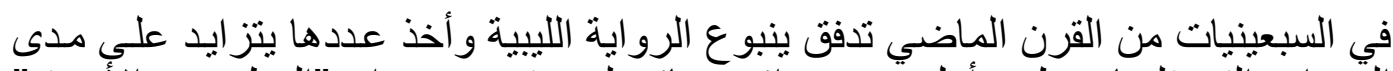

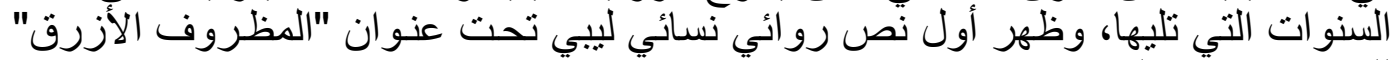
للكاتبة مرضية التئة النعّاس. تفردت المر أة في الرواية النّسائية الليبية بدور البطولة المطلقة وكثرة الحضور و التأثير في

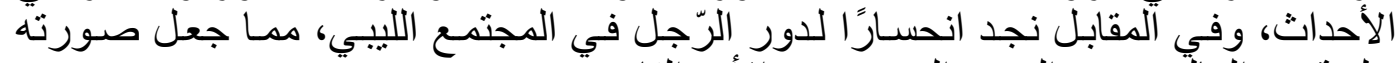

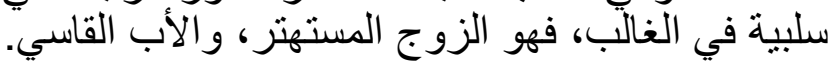

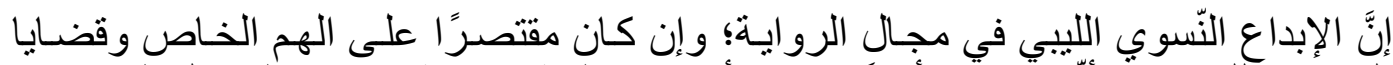

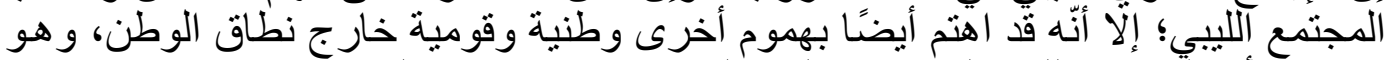

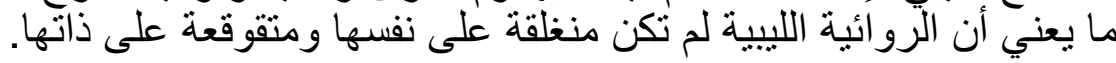


خمنينيات القرن العشرين علي يد زعيمة الباروني و خديجة الجهمي و مرضية النعاس و غيرهن من الأصوات النسائية فأنتجت نصوصا ادبية كانت مرتكزا للأبب النسائي فيما بعد و رافدا من روافده المهمة فبرزت المرأة القاصة و الصحفية و الثاعرة و الروائية مثبتة بذلك مكانة المرأة علي خارطة الابداع الليبي و العربي, لقد رسمت الأديبات واقع المرأة المريز الذى عاشته وقاست ويلاتهه ردحا من الزمن و صورن هموم الأنثى الني تسيطر عليها ، و أدركت بعضهن أن الرواية هي النص الأدبي الأرحب لاحتواء عالم المرأة المثير و المغرى بالاكتشاف. كما أدركن بعضهن أن الكتابة هي ضرب من ضروب التحرر. و هن هنا ظهرت الروايات النسائية الجديرة بالدراسة و الوقوف علي أبرز السمات الني تميز النص الإبداعي. وتكمن أهمية الفن الروائي في نقله صورة المجنمع بما يحويه من مشاكل و أزمات و مظاهر تقدم أو تخلف ، كما أن الفن الروائي ينقل للقارئ تطور واقع المرأة فى سي مختلف مراحله ، فالنصوص الإبداعية النسائية - و الروائية منها علي الأخص إنما هي أفضل ممثل لواقع المرأة و في تصوري أن النصوص التي تَ اختيارها لتكون موضوع الدراسة هي نماذج صادقة لما كانت تعانيه المرأة الليبية - باعتبارها أنثى - خله الفترة الممتدة من السبعينات حتى التسعينات من القرن العشرين 